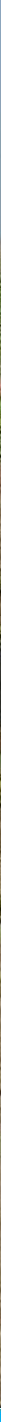

\title{
Report Topsector Potato India and Ethiopia 2015/16
}

Annette Pronk, Anton Haverkort, Lubbert van den Brink, Bas Janssens, Ben Meijer, Frank ter Beke, Sicko de Vries, Maureen Schoutsen, Jean-Marie Michielsen \& Corné Kempenaar

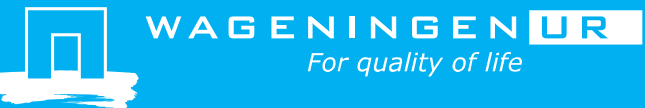





\section{Report Topsector Potato India and Ethiopia 2015/16}

Annette Pronk ${ }^{1}$, Anton Haverkort ${ }^{1}$, Lubbert van den Brink ${ }^{1}$, Bas Janssens ${ }^{1}$, Ben Meijer ${ }^{1}$, Frank ter Beke ${ }^{1}$, Sicko de Vries $^{1}$, Maureen Schoutsen ${ }^{1}$, Jean-Marie Michielsen ${ }^{1} \&$ Corné Kempenaar $^{1}$

${ }^{1}$ Wageningen University \& Research

This study was carried out by Wageningen University \& Research and partners. It was commissioned and financed in part by the Dutch Ministry of Economic Affairs within the context of the Policy Support International research theme. Other financial resources were provided by the Dutch private partners and the Indian private partners. The project was programmed within the Topsector AgriFood, Theme International (AF 11). 
Pronk, A.A., A. J. Haverkort, L. van den Brink, S.R.M. Janssens, B. Meijer, F. ter Beke, S. de Vries, M. Schoutsen, J.M. Michielsen1 \& C. Kempenaar, 2016. Annual Report Topsector Potato India and Ethiopia 2015/16. Wageningen Research, Report WPR-687. 86 pp.; 29 fig.; 19 tab.; 24 ref.

The potato production analysis of Gujarat and Punjab continued in 2015/16. At each winter project meeting it was decided which topics needed to be investigated in 2015 and 2016. Several topics of previous years are investigated in more depth and new topics are included. Short abstracts of each topic are presented in the Executive summary. Further details are found in the subsequent chapters.

Keywords: skin curing, haulm killing, frozen potato market, storage, seed, Centre of Excellence, Centre of Potato Expertise

The pdf is free of charge and can be downloaded at http:/dx. doi.org/10.18174/418740.

(C) 2017 Wageningen, Stichting Wageningen Research, Wageningen Plant Research, P.O. Box 16, 6700 AA Wageningen, The Netherlands; T +31 (0)317 4807 00; www.wur.eu/plant-research

Chamber of Commerce no. 09098104 te Arnhem

VAT NL no. 8065.11.618.B01

Stichting Wageningen Research. All rights reserved. No part of this publication may be reproduced, stored in an automated database, or transmitted, in any form or by any means, whether electronically, mechanically, through photocopying, recording or otherwise, without the prior written consent of the Stichting Wageningen Research.

Stichting Wageningen Research is not liable for any adverse consequences resulting from the use of data from this publication.

Report WPR-687

Photo cover: Annette Pronk 


\section{Contents}

$\begin{array}{ll}\text { Preface } & 5\end{array}$

$\begin{array}{ll}\text { Executive summary } & 7\end{array}$

$1 \quad$ Introduction

11

I mproved skin curing to facilitate mechanical harvest of seed potatoes in Punjab, India

$\begin{array}{lll}2.1 & \text { Introduction } & 13\end{array}$

2.1.1 Background 13

2.1.2 The harvesting process in detail $\quad 13$

2.1.3 The purpose of the trial 14

$\begin{array}{lll}2.2 & \text { Materials and methods } & 14\end{array}$

2.2.1 Literature on skin curing of immature potatoes $\quad 14$

2.2.2 Effects of abiotic factors on skin curing of potato 17

2.2.3 Treatments and field layout: proposal 17

2.2.4 Measurements: proposal 18

$\begin{array}{lll}2.3 & \text { Research location } & 18\end{array}$

$\begin{array}{llr}2.4 & \text { Results } & 18\end{array}$

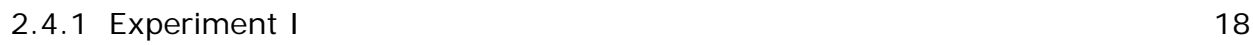

$\begin{array}{ll}2.4 .2 \text { Experiment II } & 20\end{array}$

2.5 Conclusions $\quad 22$

3.1 Overview of the Indian frozen potato product market $\quad 23$

3.1.1 Frozen potato products value chain $\quad 24$

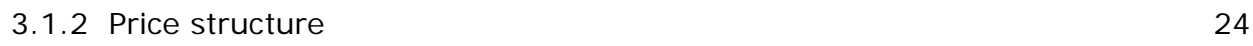

3.1.3 Long term developments in the Indian potato production 24

3.2 Frozen potato product producers in India 26

3.3 Population development: where is the market? $\quad 27$

3.3.1 Population growth and income distribution $\quad 27$

3.3.2 The market still lies and develops in the cities 28

$\begin{array}{lll}3.4 & \text { Food trends } & 29\end{array}$

3.4.1 General Indian food consumption trends and habits 29

3.5 Sales channels of frozen potato products 30

3.5.1 The retail market 30

3.5.2 The QSR market $\quad 31$

3.5.3 Concluding remarks $\quad 32$

3.6 Obstacles hampering the development of the frozen potato product market and SWOT analysis $\quad 32$

3.6.1 Lack of cold chain facilities $\quad 32$

3.6.2 Unreliable electricity supply 33

3.6.3 How is the market expected to be dealing with the obstacles? 34

3.7 Small packaging of fresh potatoes: is this feasible? $\quad 35$

3.7.1 Overview of the fresh vegetable market $\quad 35$

$\begin{array}{ll}3.7 .2 \text { Packaging } & 35\end{array}$

4.1 Preliminary studies on cold storage, 2015

4.1.1 Real Cold Store $\quad 37$ 
$\begin{array}{lll}5.1 & \text { Introduction } & 49\end{array}$

$\begin{array}{lll}5.2 & \text { Steps to be made } & 49\end{array}$

I mpressions of I lanBio's micro-tubers: production, use and R\&D aimed at exploitation

6.2 Steps forward from a research perspective $\quad 53$ Centre of Potato Expertise (COPE) at Ludhiana (Punjab)

7.1 The Centre of Excellence $\quad 55$

7.2 The Centre of Potato Expertise $\quad 55$

8.1 Introduction $\quad 57$

8.2 Support to the Potato Platform based at the Addis Ababa Chamber of Commerce (ABSF) 57

8.2.1 Deliverers of crop inputs (substances and services) 57

8.2.2 Producers of seed potatoes $\quad 57$

8.2.3 Potato processors $\quad 58$

$\begin{array}{lll}8.3 & \text { Support to the Veris Investment FDOV project } & 61\end{array}$ internationally competitive level

$\begin{array}{lll}9.1 & \text { Executive statement } & 63\end{array}$

9.2 Reading guide $\quad 63$

$\begin{array}{lll}9.3 & \text { Introduction } & 63\end{array}$

$\begin{array}{lll}9.4 & \text { Addressing three issues } & 65\end{array}$

$\begin{array}{lll}\text { 9.5 Follow up on the policy brief Punjab Seed Potato } & 67\end{array}$

$\begin{array}{lll}10.1 & \text { Missions, symposia, contacts } & 71\end{array}$

$\begin{array}{lll}10.2 & \text { Presentations } & 72\end{array}$

$\begin{array}{lll}10.3 & \text { Publications } & 73\end{array}$

$\begin{array}{ll}\text { References } & 75\end{array}$ 


\section{Preface}

The Agricultural Counsellor of the Netherlands Embassy in Delhi initiated a BOCl project 'Overview of the potato chain in India' in early 2011. In September 2012 this initiative has been adopted by the Dutch and Indian stakeholders and the Pubic Private Partnership (PPS) was established to facilitate the intensification of collaboration between Dutch and Indian stakeholders of the potato chain. A team of Wageningen UR researchers was commissioned to carry out this project.

In 2011, the team collected information from reports, personal files, internet and some Dutch companies and reported the information in "An overview of the potato sector in India and prospects of Indo \& Dutch cooperation". The team also participated in the Netherlands Trade mission to India (5\& $11 \mathrm{~J}$ une 2011) and visited the Central Potato Research Institute at Shimla. Furthermore jointly with the Agricultural Counsellor we organized a potato seminar to present our findings on 5 October 2011 in Delhi. Major potato stakeholders both from India and from the Netherlands attended the seminar; total number of participants was about 60 persons.

In 2012, 2013, 2014, 2015 and 2016 the team carried out different tasks such as presenting information on various subjects of the Dutch and Indian potato chain to exchange knowledge. In addition, several identified subjects were investigated. All actions and activities aimed to facilitate collaboration between Dutch and Indian stakeholders. Visits to different locations of India accompanied by Dutch stakeholders, meetings with experts of the Indian potato production chain both stakeholders and researchers, and topics such as skin curing and chemical haulm killing, reduce storage losses and the establishment of the Centres of Excellence (CoE) in Punjab (Jalandhar) and Uttar Pradesh, and the Centre of Potato Expertise (COPE) at Ludhiana (Punjab) were successfully accomplished.

The WUR team was steered by the Netherlands Agro Food Technology Centre (NAFTC) in Delhi. The NAFTC was in charge of facilitating the collaboration between the NAFTC DPC (Dutch Potato Centre) members and the WUR researchers. The collaboration with NAFTC is appreciated.

This report focuses on India as well as on Ethiopia.

Corné Kempenaar

Coordinator Wageningen UR research team. 


\section{Executive summary}

The potato production analysis of Gujarat and Punjab continued in 2015/16. At each winter project meeting it was decided which topics needed to be investigated in 2015 and 2016. Several topics of previous years are investigated in more depth and new topics are included. Short abstracts of each topic are presented below. Further details are found in the subsequent chapters.

Chapter 2: Improved skin curing to facilitate mechanical harvest of seed potatoes in Punjab, India During our visits to India (October 2014 and September 2015) we learned that mechanically harvesting of potatoes is difficult because the skin of the tubers is too vulnerable. Therefore, potato is still harvested by hand, collected and stored at the corner of the field to cure and transported at the end of February to the storage facility. It is hypothesised that alternative haulm killing techniques induce faster skin curing which then facilitates fully mechanical harvest and transport to storage facilities. Effects of spraying chemicals and pulling vines of potato on skin curing were compared to the traditional technique of haulm killing, haulm cutting in Kufri Pukhraj. Skin resistance as measure of skin firmness was evaluated at haulm killing, and 22 and 69 days thereafter with the Halderson periderm shear tester.

This investigation yielded the following conclusions:

- Haulm killing through the application of chemicals can only be effective when the spraying is done correctly.

- The use of haulm killing chemicals did not promote faster curing of the immature haulm killed crop compared to the traditional haulm killing by cutting.

- $\quad$ The skin resistance of Kufri Pukhraj did not increase after potatoes were lifted and stored at a corner of the field. This implies that transport to storing facilities can happen any time after lifting and the end of February without increased risks on skin damage.

Chapter 3: Market study

Chapter 3 reports findings on frozen potato product market, its development and perspectives and with findings of the small package of fresh potatoes.

The frozen potato products are an important part of the frozen food market in India. The frozen food market is evolving gradually and is still in the early stage of development. For the Indian consumer frozen food is a relatively new category and consumers are slowly getting familiar with it.

The frozen potato processing market is dominated by the McCain company with a market share of $90 \%$ although new processors of Indian origin as well as foreign origin are about the enter the market. Interestingly, all frozen potato processors are so far located in Gujarat.

The frozen potato market is on the edge of a vast and rapid growth as the scale of India's young and rapidly growing population and subsequent urbanization will be immense. The major players in the frozen potato market still focus on Indian major cities (especially Tier I, II and III) as market penetration of frozen food products is not easy because of an underdeveloped frozen food distribution network. However, the younger and growing middle class population will increasingly eat outdoors and spent more of their income on out-door meals including eating out in a western setting and out-door French fries consumption. Additionally, they are expected to travel increasingly by car which facilitates visits to outlets of frozen food products at highway restaurants. The major identified weakness in the frozen product chain is the lack of cold chain facilities and the 24-hour availability of electricity to run the cold chain facilities.

The small package of fresh potatoes is rarely done and only scarcely small packed fresh potatoes in 1.3 or $5 \mathrm{~kg}$ bags are sold. No information is provided with packaged potatoes such as origin, variety or how to prepare/use the potatoes. Looking at the potato supply, consumers are at the mercy of traders and supermarkets and don't have much knowledge of potatoes. A new development is that 
supermarkets increasingly buy potatoes on contract directly from cold stores thus cutting out the middlemen. Cost increasing activities like packaging potatoes is not supported by the government as their aim to keep consumer prices of food low.

Chapter 4: Potato storage experiments

The Indian potato processing companies require raw material throughout the year. The raw material is supplied freshly from the field during February through March and from cold stores from April through January. The raw material quality of about 300,000 tonnes (40\%) during August to January is insufficient due to poor storage management. So, continuing from 2014, storage experiments were conducted Gujarat in the Real Cold Store in Himmatnagar and the Shakti Fruits and Vegetables bag store in Palanpur in 2015, and in the Real Cold Store in Himmatnagar in 2016. Chapter 4 describes the experiments, which focused on the conditions in the cold store during storage and the effects on the processing quality of the potatoes.

The major results of 2015 revealed that:

- Harvest was delayed due to rainfall and the moment of loading the store was later than in other years and subsequently quality of potatoes to be stored was lower.

- Losses due to water loss and respiration were relatively high, about 5 to $6 \%$ and about $10 \%$ by mid-September in the Real Cold Store and Shakti Fruits and Vegetables bag store respectively.

- In the Shakti Fruits and Vegetables bag store the potato quality criteria for sticks were met 3 out of 10 locations which was better than for the traditional storage.

- Losses due to rotten tubers were relatively high, about $10 \%$, and relatively low, about $3 \%$ by mid-September in the Real Cold Store and Shakti Fruits and Vegetables bag store respectively.

- The variation in quality of samples within the cold storage was high in the Real Cold Store, indicating that storage conditions were not uniform, and small in the Shakti Fruits and Vegetables bag store, indicating that the storage conditions were uniform.

- $\quad$ Skin curing should be included in the experiments as a factor to evaluate.

Results of 2016 are yet to be reported and will be published in a separate document as an appendix of this report.

Chapter 5: Seed potatoes

India currently grows potato on approximately 2 million hectares with a yield of 23 t/ha resulting in an annual production of 46 million tons. Consumer and seed users value is approximately USD 10 billion. The amount of seed used is 3.2 million tons annually much of it is imported from Punjab and making the Indian seed potato industry probably the largest in the world. This note is intended to develop thoughts on making the Indian potato industry more competitive vis-a-vis other foodstuffs in India and vis-a-vis other exporting markets thereby possibly opening nearby markets in the region. Two features of the Indian seed potato industry differ compared to other major industries such as those of Northern Europe and North America. First, close to all varieties grown in India are bred in India by CPRI at Shimla and second, most seeds produced and planted are not officially certified. Steps to be made to initiate changes were discussed with stakeholders such as seed growers associated with Mahindra-HZPC and POSCON, governmental bodies such as CPRI, Punjab Agricultural University and government officials at Chandighar from the State Horticultural Mission and were:

- Commercial Registration of foreign varieties aimed at rapidly increasing the genetic base of potato in India allowing farmers more degrees of freedom

- Official massive certification of seed potatoes aimed at improving and guaranteeing seed health

Chapter 6: Impressions of IlanBio's micro-tubers: production, use and R\&D aimed at exploitation Within the framework of the Netherlands Topsector Public Private Partnership India-Ethiopia funded by the Netherlands Ministry of Economic affairs (MinEZ) and managed by the Netherlands Agro Food Technology Center (NAFTC) two visits were paid to Ilan Bio (http://ilanbio.com/about/profile/) in Tel 
Aviv. In April 2015 a visit was paid to IlanBio and a field trial in the Negev was visited in attendance of Mr Sujit Bhatti and dr. Gang of Bhatti farms in Jalandhar, Punjab, India. Performance was observed and avenues for cooperation explored. Suggestions for steps forward from a research perspective were:

- Carry out field research experiments with statistically viable protocols,

- Re business model a two-way development: seems adequate: IlanBio makes micros from Khandramukhi and Kufri's from India and Bhatti Farm tests it for its value from there.

- Take further R\&D from there.

Chapter 7: Centres of Excellence (CoE) in Punjab (J alandhar) and Uttar Pradesh, and the Centre of Potato Expertise (COPE) at Ludhiana (Punjab)

Chapter 7 reports on the Centres of Excellence (CoE) and the Centre of Potato Expertise.

The CoE at Jalandhar has been established with Federal funding and expertise input from the Netherlands (PUM) and sited by the Wageningen team in January 2015 to discuss work plans. However, to date no tender has been made public for stores and machinery.

The State of Punjab has committed itself to the funding of COPE to be established at the premises of the Punjab Agricultural University (PAU) within the framework of the PAU-WUR MoU. During the J anuary 2015 visit meetings were held at the Department of Finance and Horticulture at which the document "Proposal for the establishment of a "Centre of Potato Expertise" in Punjab was discussed and (re)written.

\section{Chapter 8: Activities in Ethiopia}

Chapter 8 reports on two activities in Ethiopia.

The first activity was in 2015 where a one day workshop was organised to support to the Potato Platform based at the Addis Ababa Chamber of Commerce (ABSF) addressing three issues of the potato value chain: inputs, seed producers and processors, yielding the terms of reference for a bench marking study on the recovery of potato products from potato raw material.

The second activity was a trip during April 20-25, 2015 to Addis Ababa to hold meetings with representatives of a G4AW project "CommonSense" carried out in Ethiopia and having potato as one of its target crops and with Veris Investment. Veris Investment Company wanting to establish Senselet, a potato added value company (fresh and crisps).

Conclusions from meetings and observations from visits to Ethiopia are that there are ample markets for fresh potatoes, chips and fries, and that rice, quality, availability, marketing and distribution are to be solved.

Chapter 9: Moving the Punjab seed potato industry to an environmental robust and internationally competitive level

Punjab is the major supplier of seed potatoes to the rest of India. 1.5 million tons of seed tubers are produced of which $90 \%$ goes to other Indian states. Domestic need will more than double in the next 30 years while in India a wider range of varieties is needed to accommodate the wide range of growing conditions in the country and where the suitable winter time slot may be reduced by increasing temperatures following climate change. The Country experiences seasonal surplus and shortage depending on a higher than expected crop yield due to good weather and poor crop yield due to environment pressure and disease. India has the potential to export Seed Potatoes as well as Ware Potatoes but does not have varieties easily acceptable to the export market which is largely demanding Yellow Flesh European varieties. The other challenge is difficulties in Seed Certification which have encouraged seed growers to either go for truthfully labelled seed as allowed under the law or sell seed potatoes as ware potatoes even though both the buyer and seller know that it is going to be used as seed. A pragmatic and efficient seed certification system would encourage growers to embrace the scheme and help to improve seed quality as well as give assurance to the buyers and facilitate exports. There is also a need to introduce suitable European varieties for multiplication in India to sell as seed to neighbouring countries and export as ware potatoes to neighbouring 
international markets. The export of seed will augment income of farmers whereas; the export of ware potatoes will not only increase income but also provide price stability in years of surplus production.

Chapter 10: Communication

Knowledge dissemination described in chapter 10, is a major topic within the India - Ethiopia project. In years 2015/16, a training in Utter Pradesh and Gujarat was performed as the first Knowledge Transfer activity following the signing of an memorandum of Understanding between the NAFTC and the government of Utter Pradesh in the presence of the Ambassador of the Netherlands Embassy. Furthermore, the project yielded 26 missions, 21 presentations and 7 publications. 


\section{Introduction}

India holds third position in potato area and second position in total potato production in the world (NHB 2011). About $90 \%$ of the crops are grown in the plains during the cooler autumn, winter and early spring seasons; the remaining is grown in summertime at higher elevations most in the lower Himalayas and some in Karnataka. The average national yield is around 23 tonnes per hectare (Vanitha et al. 2013); the yield level in better performing states varies from 25 - 29 tonnes per hectare for Punjab and West Bengal in 2012 - 2013 respectively (www.nhrdf.com). Potato has the third position in per capita availability of food crops after rice $\left(1^{\text {th }}\right)$ and wheat $\left(2^{\text {nd }}\right)$.

About $3 \%$ of the national seed requirement originates from the national seed potato multiplication scheme; implying that $97 \%$ of the acreage is planted which more or less degenerated seed. Cold storage capacity covers about $50 \%$ of the national production, leading to high levels of post-harvest losses after the winter crop harvests. About $1 \%$ of the national production is processed into potato chips. The cost of potato production is rather low which provides great future for processing. India is not exporting its potatoes to other countries.

The Central Potato Research Institute (CPRI) has a monopoly on variety development and seed production. Imports of foreign varieties and seed is banned although processing companies may negotiate exemptions.

Several opportunities for cooperation between Indian and Netherlands companies and institutions were identified. The themes for cooperation are: varietal development; seed production; introduction of Good Agricultural Practices (GAP); improving storage, storage management and processing qualities; yield gap analysis and yield increase goals; production of high quality raw material for potato processing factories. It is suggested that the implementation is to be carried out in a Public Private Partnerships (PPS). More information on the background of India is provided by Wustman et al. (2011). That study proved that a PPS would significantly stimulate the stakeholders market opportunities throughout the potato production chain. As from 2012 the PPS was established and the tasks are being executed.

The Netherlands Agro Food Technology Centre (NAFTC) was established to facilitate the collaboration between its (potato) members and the WUR researchers. The WUR team informed NAFTC on all its activities such as visits and workshops.

The purpose of the visits and workshops is:

- To exchange information and knowledge on the Indian potato production chain,

- To investigate possible benefits of mechanization in potato production and handling,

- To perform a market study into the developments of

1) the Quick Service Restaurant business and

2) the packaging of fresh potatoes in India,

- To evaluate potato storage experiments in Gujarat,

- To present chain solutions and introduction of innovations, new products and approaches,

- To improve transparency in seed potato certification and transparency in potato varietal testing for DUS and VCU,

- To facilitate the establishment of the Centre of Potato Expertise in Punjab,

- To assist the potato Platform of the Addis Ababa Chamber of Commerce in Ethiopia in realizing its goals.

A team of Dutch potato specialists was composed to carry out the above presented tasks. Contacts in India were established with McCain, POSCON and Punjab Agricultural University (PAU). After the field trial of the yielding performance of potatoes from different storage facilities in Punjab 2013, a study 
was initiated of the storage systems of Gujarat. Farmers interviews were done to investigate economic aspects of the potato production in Punjab and Gujarat. The interviews were also used to collect information to identify possibilities to introduce mechanization in the potato production. Harvest and post-harvest were identified possibilities and a field trial was initiated. The results were shared with stakeholders and farmers.

Visits to Gujarat and Punjab contributed to initiate discussions, facilitate exchange of information and support innovations. The J une 2016 workshop in Punjab yielded the Policy Note "Moving the Punjab seed potato industry to an environmental robust and internationally competitive level" which has been discussed with Government representatives in December 2016.

Contacts in Ethiopia were established with IlanBio, potato Platform of the Addis Ababa Chamber of Commerce and Solagrow. These contacts provide ample opportunities to continue collaboration on new innovations and techniques. 


\section{Improved skin curing to facilitate mechanical harvest of seed potatoes in Punjab, India}

Annette Pronk \& Jean-Marie Michielsen, Wageningen University \& Research, Wageningen, The Netherlands

\section{$2.1 \quad$ Introduction}

\subsubsection{Background}

During our visits to India (October 2014 and September 2015) we learned that mechanically harvesting of potatoes is difficult because the skin of the tubers is too vulnerable. Therefore, potato is still harvested by hand. We also learned that:

- Labour costs are likely to increase in the near future and thus increasing manual haulm killing and harvesting costs,

- farmers would greatly benefit if fields are cleared one week or ten days earlier to facilitate earlier planting of the next crop,

- the period that potatoes are transported to the cold storages is very short as temperature rises fast and unpredictable and subsequently causing the region to suffer from labour demand peaks and traffic jams of tractors.

All above mentioned aspects are related to skin curing of the immature seed potato. If the periderm forming is advanced through the haulm killing technique the curing time in the soil can be shorter, mechanical lifting is possible and transport to the storage can be done gradually over time.

\subsubsection{The harvesting process in detail}

Mechanical harvest requires a certain stage of skin curing as peeling and bruising of the potato must be prevented at any time. Seed potatoes in Punjab are haulm killed prematurely for crop quality reasons by manually haulm cutting between 15 and 31 December. After approximately 30 days curing in the field, the potatoes are lifted with a potato-digger in the early morning, dried on manually gathered small heaps on the field until noon ( $14.00 \mathrm{hr}$ ), after which they are manually bagged in 50 $\mathrm{kg}$ bags filled half and brought to a big heap at the field-edge. There potatoes are bulk stored for another 3 to 4 weeks to cure (Figure 2.1). These large heaps are covered with rice straw mostly grown by farmers themselves as rice straw is normally chopped when mechanically harvested. After 3 to 4 weeks, the potatoes are manually put into $50 \mathrm{~kg}$ bags, manually loaded on a trolley or truck and transported to the storage facility. Grading can either be done by hand of by a mobile grading machine at the field. In some cases, grading is done when potatoes arrive at the cold store before loaded into the cold store. However, this means that potatoes have to be unbagged for grading, and bagged again to be stored.

The harvesting process is labour intensive and cost for labour are likely to increase in the near future. Techniques to replace all labour are available. However, the skin is not cured enough to withstand mechanical harvest. As skin curing can be advanced, the period between haulm killing and lifting can be shortened as well as mechanized and farmers will greatly benefit. 


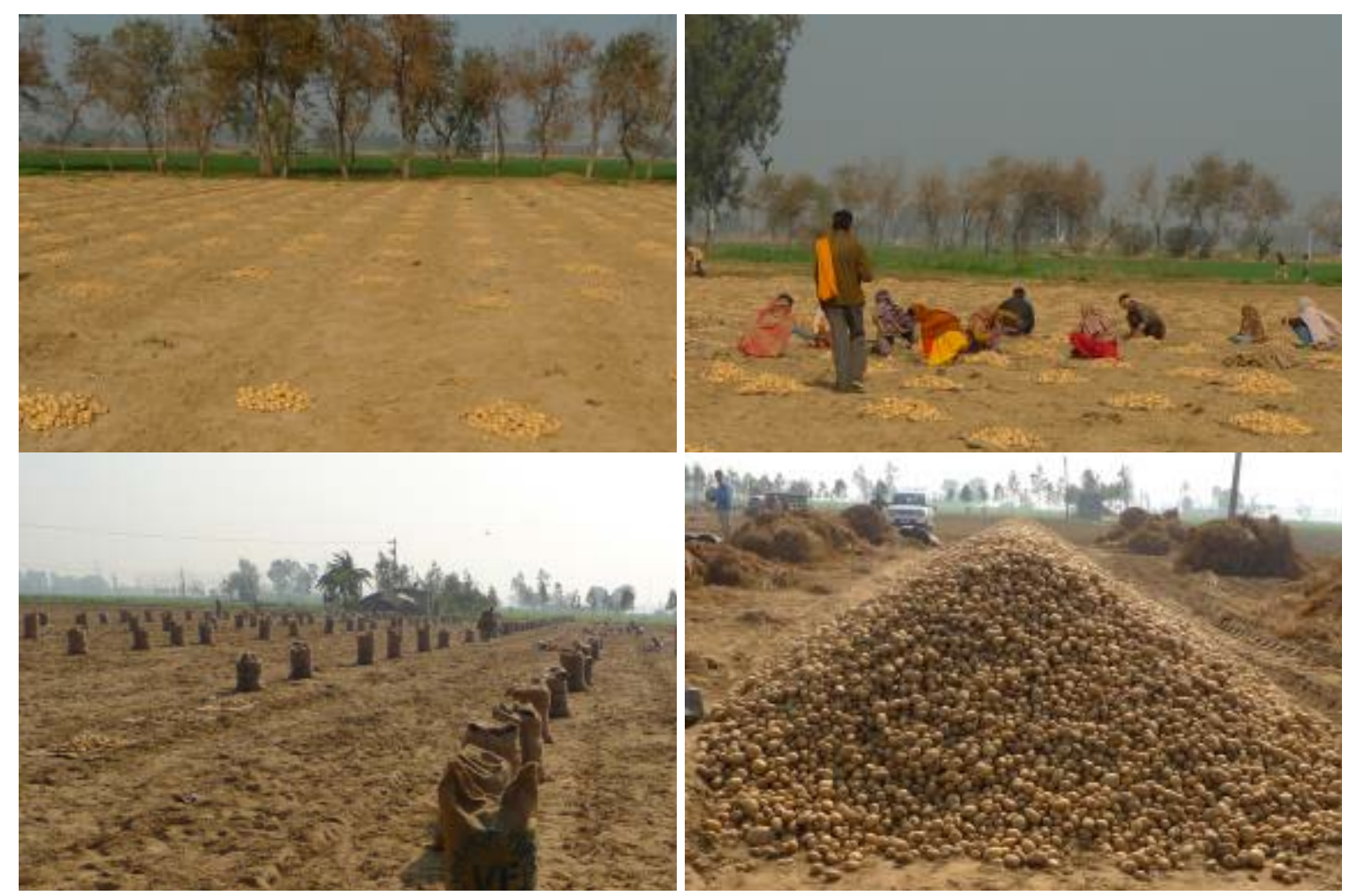

Figure 2.1. Small heaps of potatoes left to dry (top left), after some hours put on Jude bag (top right), collected in $50 \mathrm{~kg}$ Jude bag (bottom left) and transported to a larger heap of potatoes to cure for another 15 to 20 days (bottom right). The rice straw is shown on large heaps next to the potatoes.

\subsubsection{The purpose of the trial}

The purpose of this proposal is to investigate possibilities to advance skin curing of green haulm killed seed potatoes during wintertime in Punjab. The investigation is done through a trial on the effects different haulm killing techniques on skin curing. An increased curing has several benefits for growers: it allows fully mechanical harvest of the potato to replace manual handling, the field is available for the next crop much earlier and the period that potatoes can be transported to the cold storage will increase.

\subsection{Materials and methods}

\subsubsection{Literature on skin curing of immature potatoes}

\section{Skin curing}

Skin curing is part of the native periderm maturation (Lulai 2007). Before senescence tubers are covered with an immature periderm which is fragile and susceptible to bruising and peeling. To advance maturation and skin curing potato vines are killed (Kempenaar \& Struik 2007). Besides advanced maturation and skin curing, a third reason is to allow a timely and easy operation of harvesting by reducing vine quantity and releasing tubers from stolon's and stems. In seed crops, some additional objectives are identified by Kempenaar and Struik (2007):

- To stop tuber growth in order to reduce seed size and to obtain a uniform size distribution with a maximum proportion of the tubers in the most profitable size class;

- To reduce the risk of spread of virus infection by inhibiting plant-to-plant spread through vectors such as aphids;

- To suppress the development of seed-borne survival structures of fungi (e.g., sclerotia of Rhizoctonia solani, i.e. black scurf); 
- To influence the development of dormancy and physiological ageing of the seed tubers during storage. When tubers are allowed to grow longer they will have a shorter dormancy and start to age earlier.

So haulm killing has a profound effect on crop maturity and skin curing. In general, three techniques are used for haulm killing:

- Mechanical and or physical haulm killing (cutting, chopping, pulling, flail mowing, rolling, flaming, ...)

- Chemical haulm killing,

- A combination of above mentioned techniques, in which tuber maturation is speeded up and haulm killing is more effective than with only mechanical or chemical techniques.

Kempenaar and Struik (2007) state that the method of haulm killing has an effect on possible skin damage, regrowth and associated risks of virus infections (seed potatoes), and control of soil-borne diseases including black scurf (Rhizoctonia solani).

Effects of haulm killing method on skin curing

The effects of cutting, pulling, green-crop harvesting, cutting and local chemical destruction, and chemical destruction on maturity and skin setting are summarized below.

Haulm cutting is a good method for crops near maturity, for crops harvested manually, and for crops which are marketed soon after harvest. For seed potatoes however, which are relatively immature when haulms are killed, the skin hardening process after haulm killing is slow and the risk for regrowth of new shoots is high. After haulm cutting skin setting is rather slow and tubers may become affected by black scurf.

Haulm pulling induces a rapid skin setting and reduces skin damage at harvest. Additionally, the development of black scurf on tubers in the soil is slower. After haulm pulling no regrowth occurs as the connection between vines and tubers no longer exists. But haulm pulling may cause problems with greening of tubers as potatoes are pulled out of the row. On top of the row potatoes are also easily attacked by tuber moths and tubers may get exposed to high temperatures. The method is labour intensive.

Green-crop harvesting is a method in which vines are removed, potatoes are lifted and dropped in between the rows, covered by soil and left for the skin to cure (Molema et al. 1995). This method is found to be very effective to control Rhizoctonia solani (Kempenaar \& Struik 2007). As this technique separates the tubers from the vines totally, this method induces a comparable rapid skin setting as haulm pulling.

Cutting and local chemical destruction is a reliable technique although expensive. The benefits of both mechanical and chemical haulm killing are combined.

Chemical haulm killing stimulates skin setting compared to no haulm killing (Bethke \& Busse 2010). However, the success of the chemical application depends very much on the weather conditions. This technique requires little labour and investments but may have negative side effects on soil-borne diseases and tuber quality related to differences between the mode of action of the active substances and the extent to which the active substance is systemic in the plant. In seed crops with a strong vegetative growth, one application may not be sufficient to adequately kill the crop.

Besides haulm cutting, the above mentioned techniques to kill potato vines are not yet practices in Punjab. Haulm pulling and green-crop harvesting do not seem very applicable at this moment as pulling the shallow planted potatoes is likely to increase greening of the tubers (even more). Greencrop harvesting is a mechanical harvesting technique that most likely is too rough on the immature seed potatoes.

Methods of skin setting measurements

Skin pyrocatechol to identify damage on skins 
Damage on potatoes caused by falling or bruising is evaluated in a rather simple way by submerging the damaged potatoes in a pyrocatechol solution (O'Leary \& I ritani 1969). Following Bouman and Bouma (1983) batches of 100 tubers size 45/55 were passed through a tumbler to simulate mechanical transport of the potato on a harvesting machine (Figure 2.2, left). After this induced damage, potatoes were visually evaluated on skin pealing and submerged into a pyrocatechol solution for approximately 1 minute. Damaged skins turn brown in 3 to 5 minutes due to a reaction of pyrocatechol with the protein tyrosine released by tubers when damaged. Tubers are classified in three classes: $1=>$ light, $2=>$ moderate and $3=>$ severe damaged (Figure 2.2, right). In the class light 0 to $33 \%$ of the surface of the tubers is damaged; in the class moderate 33 to $66 \%$ of the surface is damaged and in the class severe 66 to $100 \%$ of the surface is damaged. The 'index' is calculated by:

Index $(" 0-100 \% ")=(\%$ light +3 " $\times " \%$ moderate $+6 \times \%$ severe $) / 6$
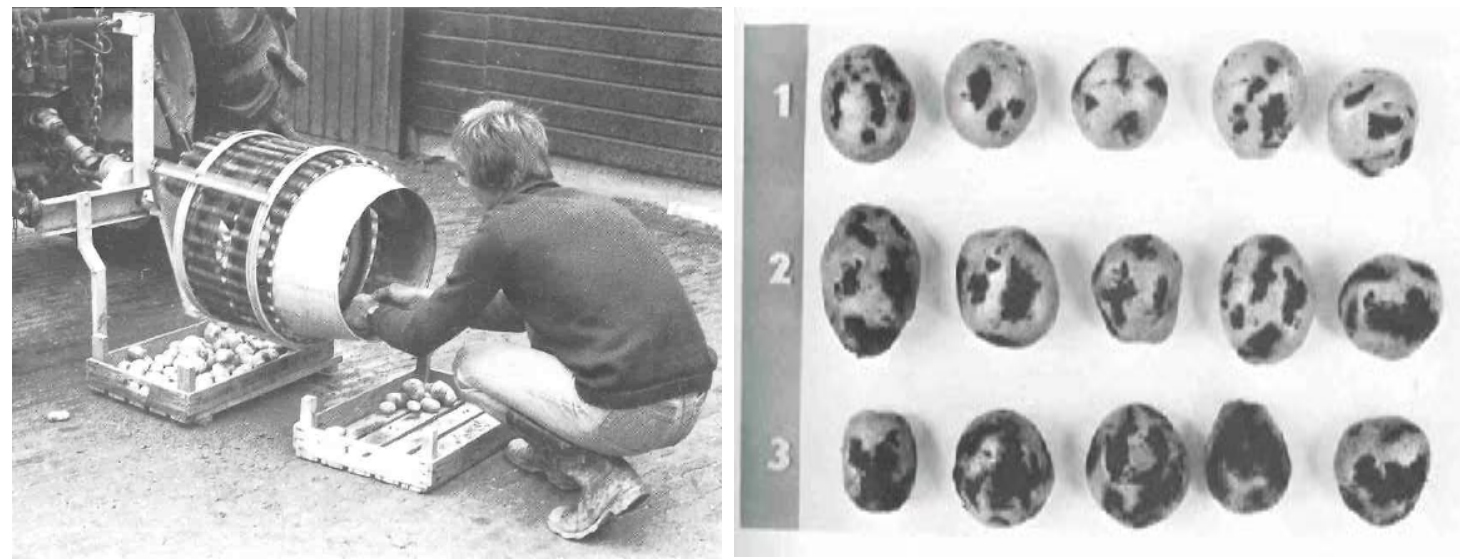

Figure 2.2. Example of skin damage inducement (left) and damage class light (1), moderate (2) and severe (3, right).

The Halderson periderm shear tester

Skin set can be quantified using a skin-set tester as developed by Halderson and Henning (1993), with some modifications according to Lulai and Orr (1993):

"The skin-set testing device and operational procedure were initially developed by J.L. Halderson and R.C. Henning. We attached the Halderson skin-set testing device to a Snap-on "Torqometer" (registered trade mark name), model TQSO50FUA (0-96 oz in/0-678 mNm range). The torqometer was equipped with a "main pointer", which provided real-time readings, and a "follow-up pointer", which indicated the maximum torque reading reached in shearing the skin during a skin-set measurement (Figure 2.1). The maximum torque reading was recorded as the measured skin-set value. A small steel flywheel $(0.9 \mathrm{~cm}$ thick $X 2.0 \mathrm{~cm}$ diameter) was fabricated and fitted to the shaft of the skin-set tester to provide sufficient inertia to prevent the torquometer's main pointer from recoiling past zero as the skin abruptly sheared; this was necessary to maintain calibration of the main pointer at zero at the start and end of each test. For the $1990 \mathrm{crop}$, the skin-set testing device was fitted with a $1.3 \mathrm{~cm} 2$ rubber tip (size 0 test tube stopper) to grip the native periderm while it was being torsionally delaminated from the cortical tissue beneath it. The rubber tip of the device was applied to the tuber with a spring setting of $31 \mathrm{~N}$ as a standard contact force perpendicular to the tuber surface. For the 1991 crop, a $1.5 \mathrm{~cm} 2$ rubber tip (size 1 test tube stopper) and $53 \mathrm{~N}$ spring setting was used. Results from the 1990 and 1991 crop were analysed separately because of the above differences in testing parameters."

Pavlista (2002) used this method and provided a relationship for the varieties Atlantic and Snowden between torque power and skin damage (\%). This allows a certain percentage of damage to relate to skin setting by torque strength.

In this trial we do want to identify the torque strength (or skin-set) which allows mechanical harvest. For Atlantic the torque strength for $10 \%$ allowable damage was estimated at:

Torque $\left(\mathrm{raN}^{*} \mathrm{~m}\right)=354-(1.4 * 10 \%)=340 \mathrm{mNm}\left(\mathrm{R}^{2}=0.83\right)$ 


\subsubsection{Effects of abiotic factors on skin curing of potato}

The maturing of the skin or periderm is likely to depend on the abiotic factors temperature and humidity. Effects of temperature are presented in Figure 2.3.

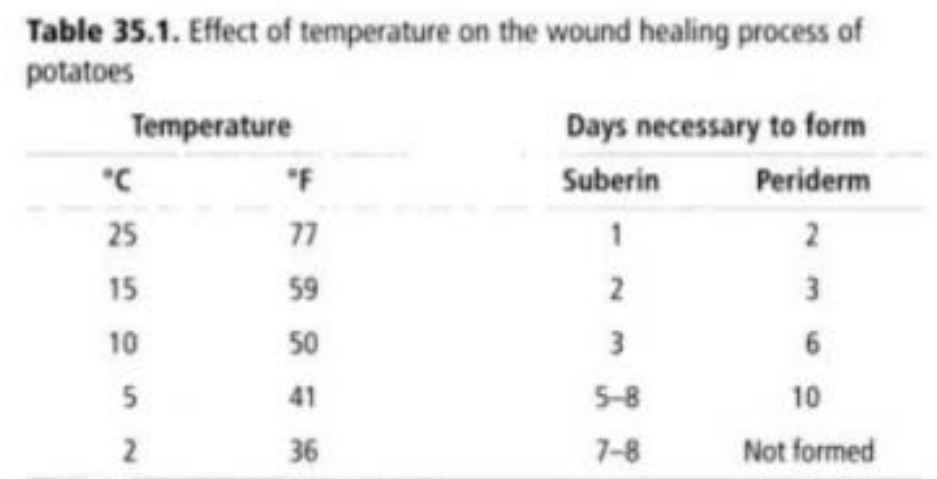

Source: Adapted from Burton 1982.

Figure 2.3. The effect of temperature on the wound healing process of potatoes.

Effects of humidity are presented by Lulai and Orr (1993). In their trial curing is best done by $18^{\circ} \mathrm{C}$ and a relative humidity of $50 \%$. Increasing humidity to $95 \%$ reduced curing as lowering the temperature to $10^{\circ} \mathrm{C}$ did. After 18 days the skin was able to handle over $700 \mathrm{mNm}$ before pealing occurred for varieties Norchip and Norland. Kennebec and Redsen however, stagnated at $400 \mathrm{mNm}$.

\subsubsection{Treatments and field layout: proposal}

Treatments focus on fastening the skin curing of green haulm killed seed potatoes. Effects of treatments are compared to the traditional method of skin curing which is leaving the potatoes in the soils after manual haulm killing with a sickle for approximately 30 days. One mechanism to fasten skin curing is the use of chemical treatments. The effects of chemical products depend on actual weather conditions. During wet conditions some products have a better performance or performance needs to be improved by an adjuvant. Some products have a better performance on stems than on green leaves and are thus best used in combination with mechanical haulm killing.

The following treatments are proposed (TO is the normal date haulm killing is done):

- $\quad$ Control = traditional haulm killing and leaving potatoes in the soil, on T0;

- Mechanically haulm killing (flailing) and leaving the potatoes in the soil, on day T0;

- Haulm killing with one or two sprays of Reglone: the first spray on day T0 and if necessary a second spray on day T0+5 days (active ingredient diquat dibromide, Syngenta, 2 - 4 L/ha in $500 \mathrm{~L}$ spaying liquid).

- Haulm killing with one or two sprays of Reglone: the first spray on day T0+5 and if necessary a second spray on day T0+10 days (active ingredient diquat dibromide, $2-4 \mathrm{~L} / \mathrm{ha}$ in $500 \mathrm{~L}$ spaying liquid).

- Combination of treatments: mechanically haulm killing + one spray of Finale (active ingredient glufosinate ammonium, Bayer, approximately $1.25 \mathrm{~L} /$ ha in $500 \mathrm{~L}$ spaying liquid on the stems). Note: Reglone has a poor performance when used on flailed stems.

- Combination of treatments: mechanically haulm killing + Spotlight Plus (active ingredient carfentrazone-ethyl, FMC Corporation USA, approximately $1.0 \mathrm{~L} / \mathrm{ha}$ in $500 \mathrm{~L}$ spaying liquid on stems).

Treatment B compares mechanically haulm killing with manually haulm killing. Treatments $C$ and $D$ are two chemical methods for haulm killing, if chemicals are available. Treatment $D$ is included to 
evaluate the effect of chemical haulm killing 5 days later then the control. This is not an option that is suggested to become common practice when performing well (due to sucking insects) but is included to differentiate and evaluate the effects the differences of chemical haulm killing dates.

Treatments $\mathrm{E}$ and $\mathrm{F}$ are a combination between mechanically haulm killing followed by one or two chemical sprays. The advantage of chemical haulm killing is that the process of killing is gradual. Gradual dying of the potato induces faster curing.

As skin setting is variety dependent we would like to include two varieties, a slow skin setting variety and a normal skin setting variety. Suggestions for varieties must come from POSCON members.

The treatments are best replicated 4 times to have 4 small plots of each treatment to collect data in ( 6 treatments 4 replicates $=24$ experimental units).

\subsubsection{Measurements: proposal}

The measurements focus on the effects of the treatments on the skin setting/curing over time. At the day of haulm killing a basic evaluation of the crop is needed:

Pictures of T0 and/or T0+5 ( and pictures per plot on each date of skin curing showing treatment effects of haulm killing method on $\mathrm{T} 0+5, \mathrm{~T} 0+10$ and $\mathrm{TO}+20$ )

Visual assessment of crop vigour and indication of BBCH code of crop (see Annex II)

Of each experimental plot (on the same area that is lifted for skin set testing, that is 1 row of 1 meter):

- Ground cover estimates

- Dry weight of aboveground biomass and tuber biomass

- Number of stems and number of tubers per plant

- Size, weight and visual assessment of health of tubers

- Soil moisture content (dry soil samples to 105 degree Celsius for 24 hours, T0, T0+5, T0+10, $\mathrm{T} 0+20)$

- Weather data from day of harvest to end of trial (temperature, precipitation, humidity)

- $\quad$ Specific measurements on skin setting over time are:

- Skin setting test at day of haulm killing (TO) and 5, 1015 and 20 days after haulm killing. For skin set testing 1 row of 1 meter per experimental plot (treatment per replicate) is lifted. This harvested meter potatoes is weight and divided in three equal number of potatoes with a minimum of 30 potatoes each. The three subsamples are weight again and tested for skin setting by 1 . Hand, 2. Skin pyrocatechol after induced damage and 3. Skin firmness by the Halderson periderm shear tester.

\subsection{Research location}

The treatments will be performed at farmers field of POSCON members. Most likely not all treatments are feasible as may be not all chemicals are available and/or equipment for suggested treatments and evaluation are not present.

Two locations were provided by two POSCON members.

\section{$2.4 \quad$ Results}

\subsubsection{Experiment I}

Layout of the experiment

The field chosen is close to the farmers farm, so the farmer can easily keep an eye on the development of this experiment. The potatoes in this field are planted in 3 different ways:

1. traditional: one row on a 26 inch wide ridge,

2. one row planted on a 30 inch wide ridges and 
3. two rows planted on a 30 wide ridge in a zig-zag pattern.

The trial started on 30 December 2015 with variety Kufri Pukhraj and included four treatments:

1. Standard haulm killing by cutting (farmers practice),

2. Haulm killing by manually pulling haulms by labour (and covering lifted tubers),

3. Spraying a concentration of Gramoxone of $2 \mathrm{~L} / 200 \mathrm{~L}$ water, application rate $200 \mathrm{~L}$ spraying volume / acre,

4. Spraying a concentration of Gramoxone of $2 \mathrm{~L} / 400 \mathrm{~L}$ water, application rate $400 \mathrm{~L}$ spraying volume / acre (farmer preference),

The machine to spray the chemicals is a Gaspardo Giove sprayer with XR 110.04 flat fan nozzles sprayed at 3 bar. Treatment 4 was done by two spraying events so that the application rates of the spraying per event was the same to keep the same nozzle-size and same spraying pressure. The sprayings were done from 12:00 - 16:00, sunny conditions, low wind speed with a temperature of $\sim 22^{\circ} \mathrm{C}$.

Not all treatments were done in all planting systems. Table 2.1 shows which treatment was done in which planting system.

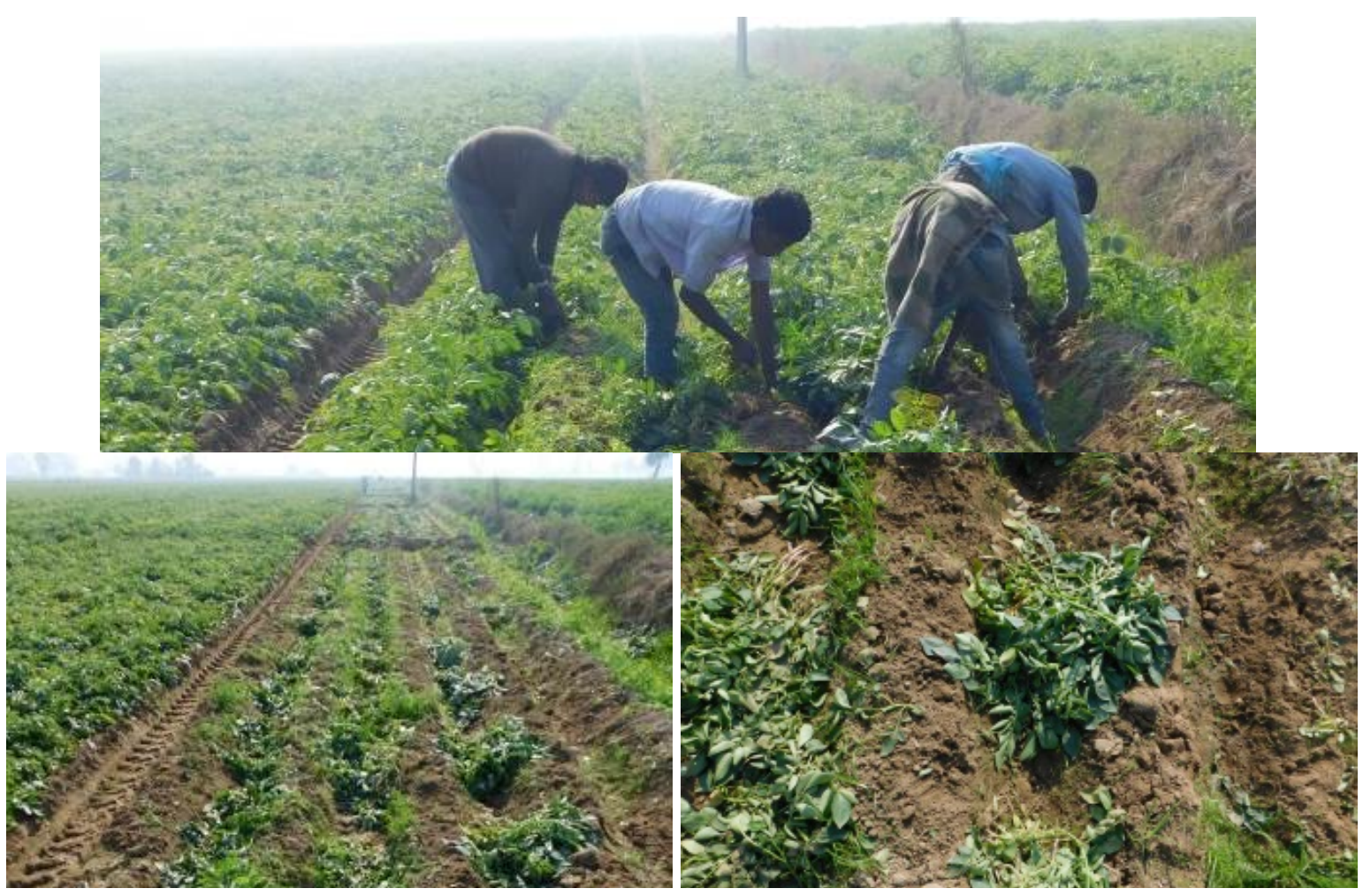

Figure 2.4. Manually haulm pulling (top) and haulms in between ridges to evaluate effects of pulling on ridges.

Table 2.1.

Treatments, row width (inch), number of rows planted per ridge and the day that the treatment was performed and skin resistance evaluated

\begin{tabular}{|c|c|c|c|c|c|c|}
\hline Treatment & row width & \# rows/ ridge & Treatment execution & Evaluation & date skin r & esistance \\
\hline Control & 26 & 1 & 03/Jan/16 & - & 22/Jan/16 & 09/Mar/16 \\
\hline Pulling & 26 & 1 & 03/Jan/16 & 03/J an/16 & 22/Jan/16 & 09/Mar/16 \\
\hline Gramoxone, 2 L/200 L/acre & 26 & 1 & 15/Dec/15 & - & 22/Jan/16 & 09/Mar/16 \\
\hline Gramoxone, 2 L/400 L/acre & 26 & 1 & 15/Dec/15 & 15/Dec/15 & 22/Jan/16 & 09/Mar/ 16 \\
\hline Gramoxone, 2 L/200 L/acre & 30 & 1 & 03/Jan/ 16 & 03/Jan/16 & - & 09/Mar/16 \\
\hline Gramoxone, 2 L/400 L/acre & 30 & 1 & 03/Jan/16 & 03/Jan/16 & - & 09/Mar/16 \\
\hline Gramoxone, 2 L/200 L/acre & 30 & 2 & 15/Dec/15 & 15/Dec/15 & 22/Jan/16 & 09/Mar/16 \\
\hline Gramoxone, 2 L/400 L/acre & 30 & 2 & 15/Dec/15 & 15/Dec/ 15 & 22/Jan/16 & - \\
\hline
\end{tabular}


Visual assessment of treatments four days after application ( $3 \mathrm{~J}$ anuary)

The haulms of treatments 3 and 4 had turned from green to brown, especially the leaves were affected as they looked curled and weak. The stems had also turned brown although some green colour was still visible. From the visual evaluation it seemed that treatment 3 ( 2 L Gramoxone / 400 L spraying volume applied per acre) had a poorer efficacy in the 26 inches rows crop than in the 30 inches rows, as still green and unaffected leaves showed.
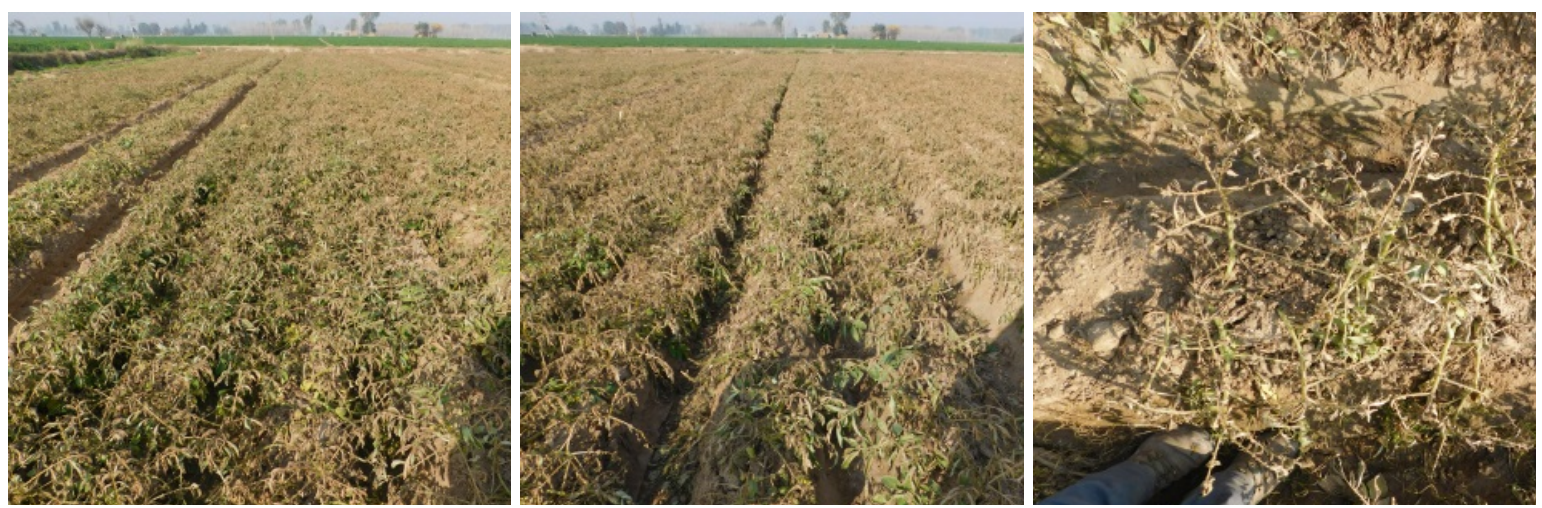

Figure 2.5. The treatments after three days: 2 L Gramoxone in 400 L/acre, 26 inches rows (left);

$2 \mathrm{~L}$ Gramoxone in 200 L/acre, 30 inches rows (middle); top view (right).

Assessment of skin resistance

The skin resistance test results are presented in Table 2.2. The skin resistance at haulm killing is low and can only stands a pressure of $151 \mathrm{mNm}$ on average. Curing in the soil for about 22 days increases resistance to $275 \mathrm{mNm}$ and leaving potatoes at the corner of the field did not increase resistance any further. The variation between measurements was large and no differences related to haulm killing treatment could be established. The increase in skin resistance is significant over time although the last measurement, at day 69 shows a slight decrease in skin resistance. This is not in line with the expectations and not explained from temperature or humidity differences during the measurements. Most striking is however, that skin resistance did not increase when potatoes were stored at the corner of the field for curing. This implies that it would not make any difference for skin damage to transport the variety Kufri Pukhraj shortly after lifting or at any time before the end of February as the skin resistance did not increase after lifting.

Differences between haulm killing techniques, cutting, pulling of spraying, were not found. Only pulling showed an increased resistance compared to the other treatments on 22 January and on 9 March.

Table 2.2.

Results of the skin resistance tests at different moments after the haulm killing by different treatments

\begin{tabular}{|c|c|c|c|c|c|c|c|c|}
\hline \multirow[b]{2}{*}{ Treatment } & \multirow[b]{2}{*}{ Row width } & \multirow[b]{2}{*}{ \# rows/ ridge } & \multicolumn{2}{|c|}{1 (31 Dec) } & \multicolumn{2}{|c|}{22 ( 22 Jan) } & \multicolumn{2}{|c|}{69 (9 March) } \\
\hline & & & Mean & Stdev & Mean & stclev & Mean & Stdev \\
\hline Cutting & 26 & 1 & - & - & 268.2 & 47.3 & 246.3 & 22.7 \\
\hline Pulling & 26 & 1 & $125.0^{1}$ & 20.2 & 317.1 & 37.6 & 259.9 & 23.4 \\
\hline Gramoxone, 2 L/200 L/acre & 26 & 1 & - & - & 253.1 & 24.8 & 224.5 & 22.5 \\
\hline Gramoxone, 2 L/400 L/acre & 26 & 1 & 158.9 & 38.1 & 269.7 & 37.7 & 237.3 & 19.1 \\
\hline Gramoxone, 2 L/200 L/acre & 30 & 1 & $183.0^{1}$ & 36.8 & - & - & 248.6 & 27.7 \\
\hline Gramoxone, 2 L/400 L/acre & 30 & 1 & 176.3 & 30.1 & - & - & 241.8 & 19.9 \\
\hline Gramoxone, 2 L/200 L/acre & 30 & 2 & 131.8 & 20.8 & 275.7 & 34.9 & 244.0 & 28.6 \\
\hline Gramoxone, 2 L/400 L/acre & 30 & 2 & 133.3 & 29.3 & 264.4 & 38.1 & - & - \\
\hline Grand Total & & & 151.4 & 37.0 & 274.7 & 41.5 & 243.2 & 25.1 \\
\hline
\end{tabular}

1 Treatment was executed on 3 J anuary (Table 2.1)

\subsubsection{Experiment II}

Layout of the experiment 
This field chosen is close to the farmers farm, so the farmer can easily keep an eye on the development of this experiment.

The trial started on 2 J anuary 2016 with variety Kufri Khayati. In this trial two different machines were used to apply the Gramoxone:

$A=$ the farmers own sprayer, local brand, Albuz yellow 600 hollow cone nozzle, sprayed at 10 bar gives $170 \mathrm{~L} /$ acre, working width $=8.5 \mathrm{~m}$ or 12 row

$B=$ the Gaspardo sprayer of the farmer from experiment I, Teejet 110.04 flat fan nozzle, sprayed at 3 bar, 200 L/acre, working width $=12 \mathrm{~m}$ or 18 row

Both machines were assumed to apply 1 L Gramoxone / acre.

The treatments were:

1. Standard haul killing by cutting (farmers practice),

2. Spraying a concentration of Gramoxone of $1 \mathrm{~L}$ Gramoxone/acre, spraying volume $170 \mathrm{~L} /$ acre, using the Albuz sprayer with 10 bar,

3. Spraying a concentration of Gramoxone of $1 \mathrm{~L}$ Gramoxone/acre, spraying volume $200 \mathrm{~L}$ water/acre, using the Teejet 110.04 sprayer with 3 bar.

During the execution of the sprayings the high pressure spraying with the Albuz sprayer, showed that the cloud of droplets penetrated the crop before the cones closed, leaving part of the crop unaffected. A proper adjustment of the spraying machine is most important for an evenly distribution of any spraying liquid in a crop. This means that the nozzles, the spraying pressure and the speed of the tractor all need to be in line with each other to result in a nicely distributed spraying pattern in the crop.
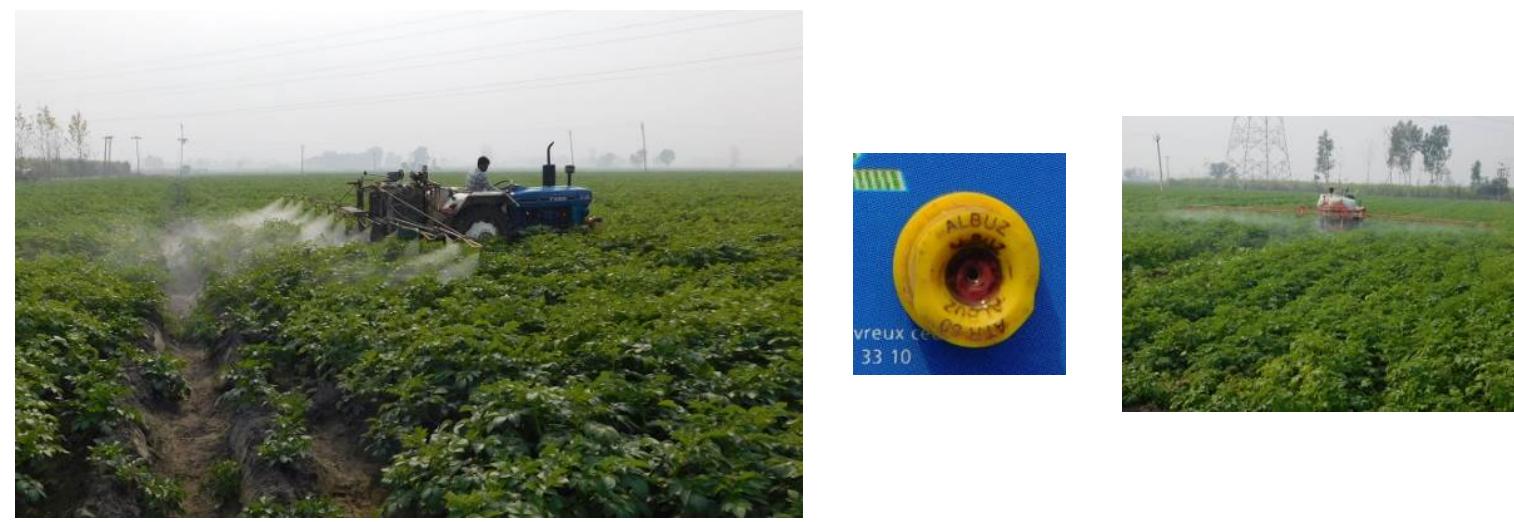

Figure 2.6. The local sprayer applying Gramoxone (left), an Albuz nozzle (middle) and the Gaspardo applying Gramoxone (right).

Visual assessment of treatments by farmer

The farmers visual assessment was that the crop died unevenly. Following that result he had the potatoes cut manually. This uneven dying of the crop was anticipated as the high pressure of the sprayer causes the chemical to reach only the rows immediately below the nozzle as can be seen in Figure 2.6 left. The crop rows in between the nozzles are hardly sprayed and did not die accordingly. This experiment demonstrated that the right spraying technique is a crucial factor in the success of chemical haulm killing potatoes.

Experiment II is not further pursued due to the incorrect dying of the crop. 


\subsection{Conclusions}

The conclusion of the investigation into improved skin curing to facilitate mechanical harvest yielded the following conclusions:

- Haulm killing through the application of chemicals can only be effective when the spraying is done correctly. This is crucial and workers need additional training on the use of the machines and the proper adjustments of the spraying equipment.

- $\quad$ The use of haulm killing chemicals did not promote faster curing of the immature haulm killed crop compared to the traditional haulm killing by cutting.

- $\quad$ The skin resistance of Kufri Pukhraj did not increase after potatoes were lifted and stored at a corner of the field. This implies that transport to storing facilities can happen any time after lifting and the end of February without increased risks on skin damage. 


\section{Market study}

Bas J anssens \& Maureen Schoutsen, Wageningen University \& Research, Wageningen, The Netherlands

\subsection{Overview of the Indian frozen potato product market}

Frozen potato products are an important part of the frozen food market in India. The frozen food market is evolving gradually and is still in the early stage of development. For the Indian consumer frozen food is a new category and consumers are slowly getting familiar with it.

Respondents indicate that:

- The sales of frozen French fries of brands such as McCain, Sumeru and Al Kabeer are growing anywhere between $15 \%-20 \%$ in their chains;

- $\quad$ French fries now account for almost $70 \%$ of the potato-based frozen snack sales (other potato-based specialties account for $30 \%$ );

- In the frozen potato products market the estimated sales distribution over the different sales channels is as follows:

o 1/3 QSR (mainly French fries, but also specialties like veggie burgers);

o $1 / 3$ Food Service (restaurants in 3 to 5 star hotels sell mainly French fries);

- $1 / 3$ retail (the retail sells $80-90 \%$ potato-based specialties (smiles, veggie burgers) and only $10-20 \%$ French fries).

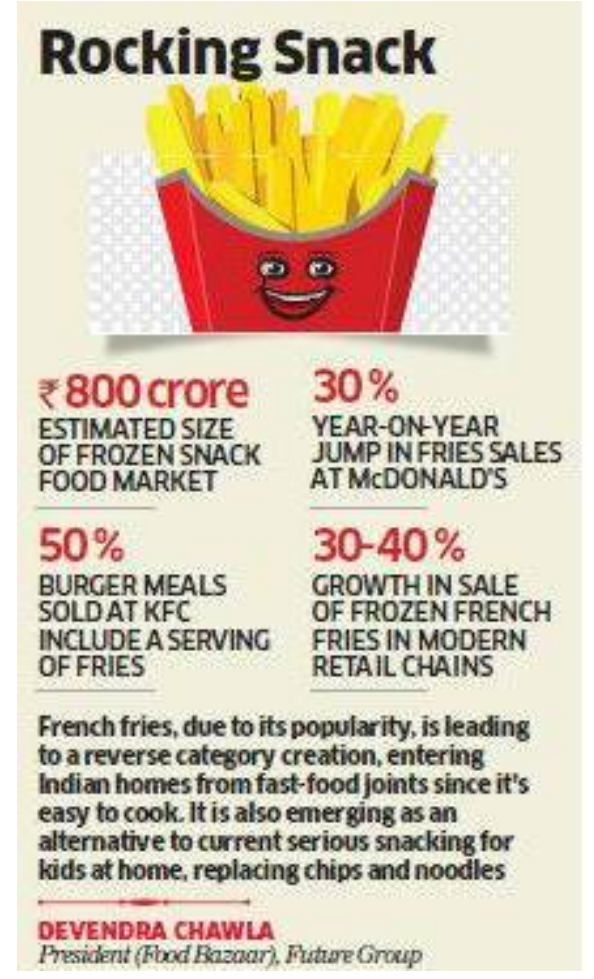

Figure 3.1 Information of the French fries market.

There is an emerging retail market for potato specialty in India. Potato is a staple food in the diet of Indian families with a huge consumption of potato preparations for both snacks and meals. McCain 
believes that India represents a wide spectrum opportunity in terms of type of potato products, from French fries to potato specialties, both international and ethnic.

Today, McCain Foods is leading in the frozen potato products segment in India ( $90 \%$ market share). Currently, McCain products are available in around 10,000 outlets across 60 Tier I and Tier II cities. The company is now targeting to expand its retail network to about 50,000 outlets in the next five years. McCain's strategy has been to target both out-of-home and in-home consumers with different products. The retail segment offers a major opportunity due to the expected growing demand from Indian consumers. The challenge for the company lies in the distribution chain: McCain controls the distribution chain until the first distribution hub (source: verbal communication). Further on down the chain the cold storage facilities are unsecure.

Basically, the frozen food market (all frozen products) is in the early stage of development. It is a market with (Mittal 2013):

- Few products,

- few players in the segment,

- Low consumer awareness levels about frozen foods,

- Underdeveloped frozen food distribution network, and

- Lack of freezer space at the retail end (low freezer penetration at retail stores).

\subsubsection{Frozen potato products value chain}

Leading brands get their labelling done from either McCain or regional players.

The frozen food segment comprises of ready-to-cook/ fry and heat-and-eat vegetarian and nonvegetarian food products. The market is largely dominated by select national brands and some regional players. The market overview depicts that in 2013 non-oven frozen potatoes registered the fastest growth in the segment with record retail value growth of $25 \%$, mainly due to the strong performance of McCain Foods that has a retail value share of $7 \%$ in the category.

\subsubsection{Price structure}

- Potatoes: $0.1-0.4 €(\text { Rs } 7-30)^{1}$ per $\mathrm{kg}$ (at least $2.5 \mathrm{~kg}$ needed for $1 \mathrm{~kg}$ fries),

- Production: $0.7-0.8 €$ (Rs 50 - 60) per kg French fries,

- Selling: $1.1 €$ (Rs 80) per kg French fries,

- Consumer price: $2.80 €$ (Rs 200) per kg French fries (distribution, frozen, margin traders, and so on).

\subsubsection{Long term developments in the Indian potato production}

According to a recent study from the Central Potato Research Institute (Anonymous 2015a) the Indian potato production will increase further on. This study predicts a very strong increase in the Indian potato processing industry: a greater amount of potatoes will be processed in the future (Figure 3.2a). The expected growth rate of the researchers is $20 \%$ per year, which is quite similar to what potato processors expect (Figure 3.2b and Figure 3.3b).

\footnotetext{
${ }^{1}$ Exchange rate: 1 euro $=75$ rupees
} 

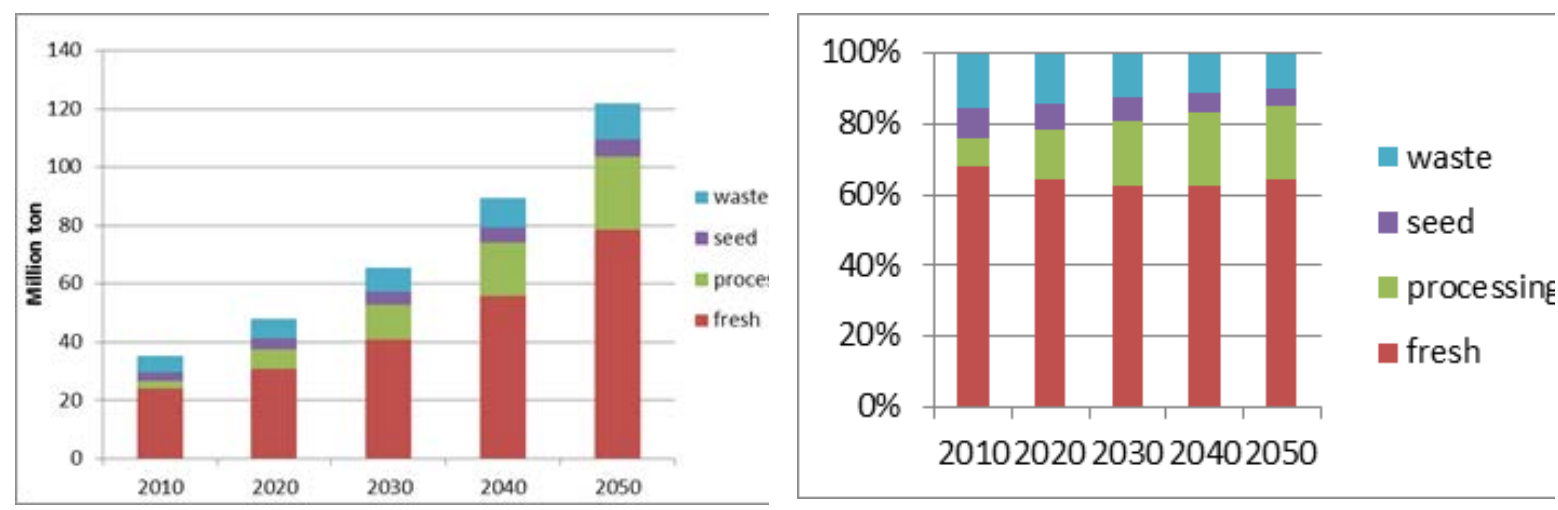

Figure 3.2 Expected growth of Indian potato production of fresh potato, processed potato, seed potato and waste2 2010 - 2050 (left) and expected growth rate (right).
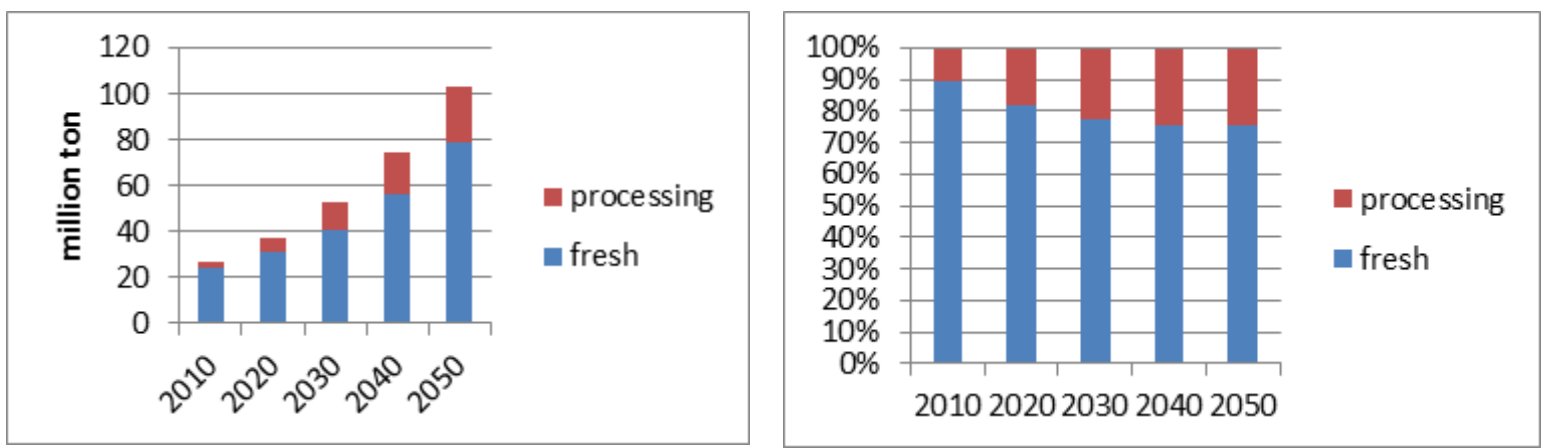

Figure 3.3 Expected growth of Indian potato production of only fresh potato and processed potato 2010 - 2050 (left) and expected growth rate (right).

Looking at the processed potato products, the strongest growth is predicted for frozen products, followed by potato crisps (chips, Figure 3.4).

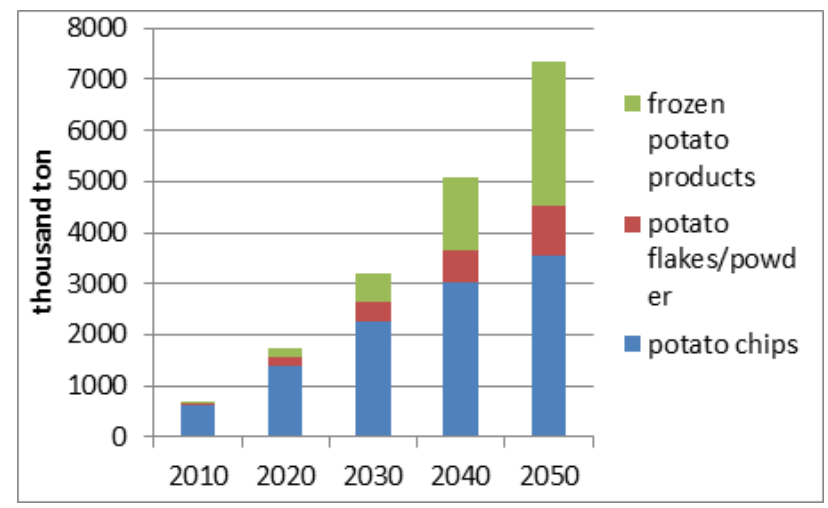

Figure 3.4 Expected growth in thousand ton of Indian processed potato products (frozen potato products, potato flakes/powder and potato chips). (Source: CPRI vision 2050, report of 2015).

\footnotetext{
${ }^{2}$ Unusable for food purposes: rottage, wastage, etc.
} 


\subsection{Frozen potato product producers in India}

McCain is known as the number one frozen potato product producer in India. The McCain company has a market share of $90 \%$. Besides McCain there are just a few smaller producers of frozen potato products (French fries) in India. Figure 3.5 shows the processing location of McCain.

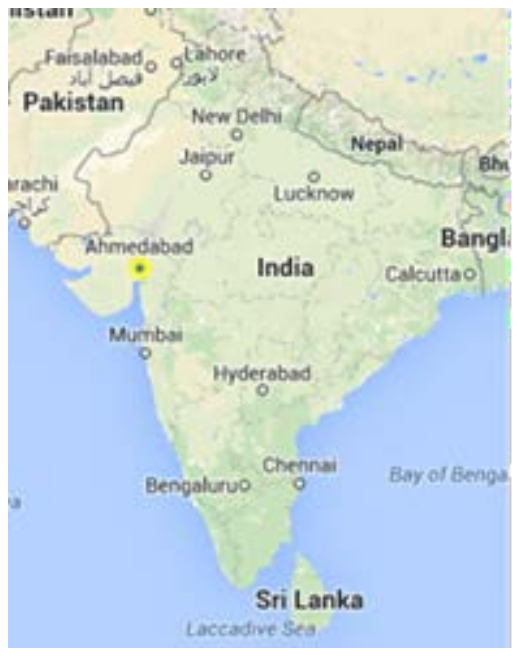

Figure 3.5 Production location of largest frozen potato products processor in India.

An overview of the current (2015) producers, their production capacity and actual production is given in the Table 3.1.

Table 3.1.

Overview of the Indian frozen food producers, their location, their production capacity and actual production (ton raw material, 2015).

\begin{tabular}{llll} 
Company & Location (and starting year) & Capacity & Processed \\
McCain & Mehsana, Gujarat (started in 1996) & 150,000 & 72,000 \\
\hline Iscon Balaji & 2015, Gujarat (started in 2015) & 5,000 & 15 \\
\hline Hyfun & Gujarat (planning to start in November 2015) & 50,000 & TBD \\
\hline Bhanu Farm (Bangur) & Madhya Pradesh (started in 2015) & 25,000 & $5,000-6,000$ \\
\hline Golden Fries & Coimbatore, Tamil Nadu (started in 2006) & 22,000 & 11,000 \\
\hline
\end{tabular}

(Sources: verbal communications, desk research)

Table 3.1 shows that the companies do not yet utilize their full production capacity. Even McCain only utilizes ca. $50 \%$ of their production capacity. This can be attributed to the fact that the sales capacity is currently still limited, due to the underdeveloped frozen food distribution network and the low consumer awareness levels about frozen foods.

Table 3.1 also indicates that beside global potato processors (e.g. McCain) new processors of Indian origin enter the frozen potato market. Besides the companies mentioned in Table 3.1 the company Simplot is also busy with preparing activities for a potato processing plant; they intend to start a processing factory in 2017.

Bhanu Farm in Madhya Pradesh sources potatoes from Gujarat. Besides Indian production a small amount (ca. $10 \%$ ) of frozen potato products is imported (Lamb Weston from USA and Agristo from Belgium).

Iscon Balaji (2015) as well as Simplot (2017) intend to start production of frozen potato products in the same Indian federal state as where the production plant of McCain is located (Gujarat). Most QSR and star restaurants sell McCain products and the greatest part (80 - 90\%; own observation) of the frozen potato assortment in supermarkets is McCain product as well. The market share of private label is still small (e.g. Sumeru and Al Kabeer), but every modern retailer wants to 
come out with his own brand as frozen fries is now a commodity. Imports of frozen potato products in India are minimal.

\subsection{Population development: where is the market?}

\subsubsection{Population growth and income distribution}

India has a young and rapidly growing population. The scale of India's urbanization, as a consequence of this population growth, will be immense.

The McKinsey Global Institute (MGI)-research shows that currently there are about 42 cities with population of more than 1 million and in 2030 this will be 68 cities. Out of these 68 cities there will be 13 with more than 4 million people, and 6 megacities with populations of 10 million or more. Big cities are important places where most supermarkets, hotels and QSR's are settled.

Also mentioned in this MGI report is the Indian urban population density classification (Table 3.2).

Table 3.2.

Indian urban population density classification

\begin{tabular}{lcc}
\hline Population by tier according to MGI & 2008 ( number) & 2030 (number) \\
Tier I > 4 million & 9 & 13 \\
\hline Tier II $1-4$ million & 33 & 55 \\
\hline Tier III and IV $<1$ million & 5000 & 6000 \\
\hline
\end{tabular}

From MGI research it also appears that about $75 \%$ of the urban citizens in 2008 lived in the bottom income segments, earning an average of $€ 1.60$ (\$1.80) a day (Figure 3.6). This large, but poor socio-economic group (the bottom of the pyramid) composes indeed a huge purchase power in the future. These poor of today are the middle class of tomorrow. Besides, there is a rapid increase of the upper middle class (from $2 \%$ in 2010 to $5 \%$ in 2020) and of the lower middle class (from $11 \%$ in 2010 to $29 \%$ in 2020 ), decreasing the bottom of the income pyramid from 86 to $64 \%$.

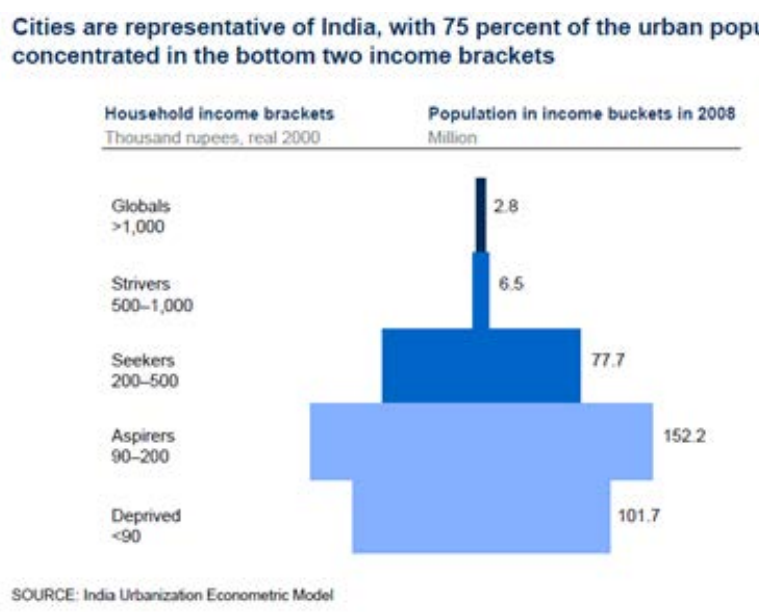

Figure 3.6 Income distribution of Indian households.

MGI projections indicate that the number of middle class households (earning between $€ 2,800 /$ Rs 200,000 and $€ 14,000 /$ Rs 1 million a year) will increase enormously between 2008 to 2020, from 32 million to 147 million. And as the distribution of Gross Domestic Product (GDP) between urban and rural areas was split almost evenly in 1995, this distribution is said to be $70 \%$ in urban India and $30 \%$ in rural India by 2030 . So cities will account for nearly $70 \%$ of India's GDP by 2030 . In Figure 3.7 we can read the predicted increase of average income of the Indian rural and urban population. 
In MGI's report by Dobbs et al. (2011) indicates that, generally speaking, companies should not only focus on covering markets within the metropolitan areas around the cities, but also reach smaller cities in close proximity and even rural areas. This so called cluster based strategy can be an attractive approach in India. McKinsey has identified 14 major clusters of cities that capture significant shares of the country's population and GDP (Figure 3.8).

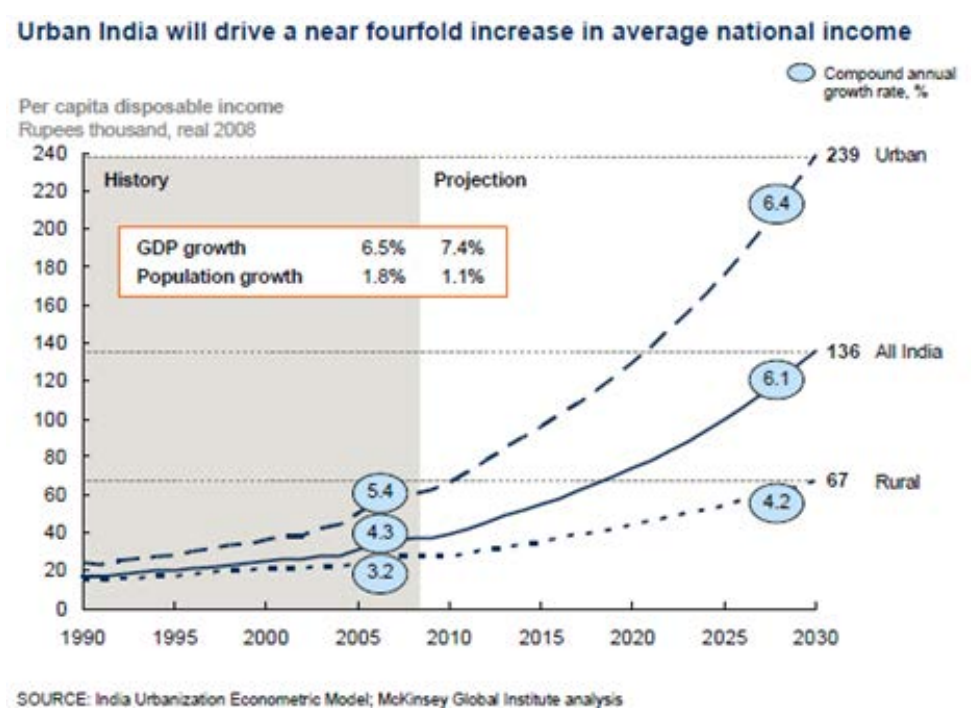

Figure 3.7 Predicted increase of average income of the Indian rural and urban population.

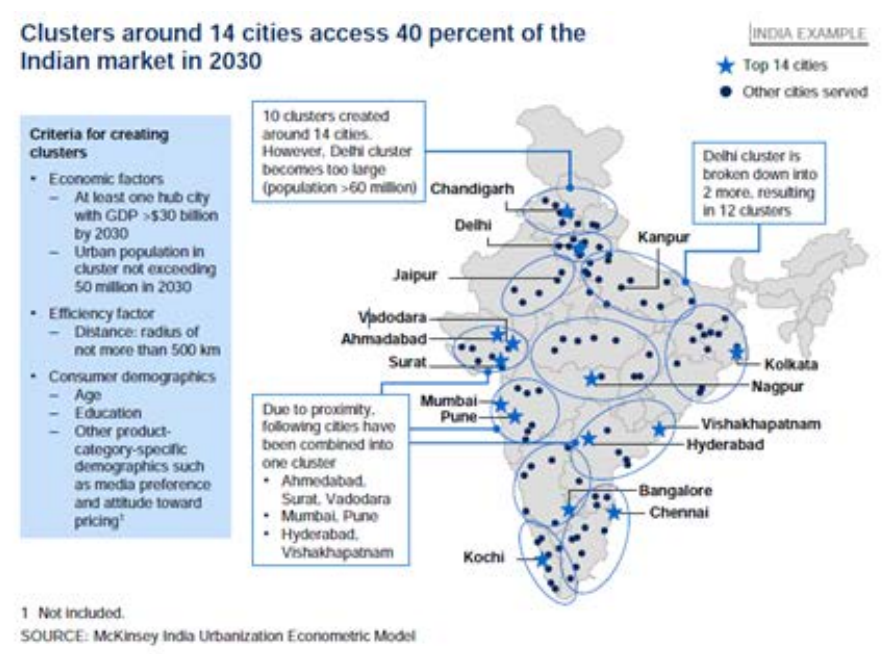

Figure 3.8 Major clusters of cities that capture significant shares of the country's population and GDP.

McKinsey indicates that specifically the next tier of fast-growing urban centres will be increasingly important drivers of global growth. A good understanding of these urban centres demographic evolution, household trends, and incomes (per cluster) will contribute to the success of entering new markets.

\subsubsection{The market still lies and develops in the cities}

In the market of frozen potato products the major players still focus on Indian major cities (especially Tier I, II and III). The market penetration of frozen food products is not easy because of an underdeveloped frozen food distribution network. Also the unreliable power supply situation in most Indian states is a big hurdle. In almost all states in India the 24/24 electricity supply is not secured 
(see also par. 3.6). There is also poor knowledge on handling of frozen products especially employees of end chain partners (retail) miss expertise.

At this moment it is too early for processors of frozen potatoes to look for market penetration at the smaller cities in close proximity of the metropolitan areas or rural areas (e.g. lack of reliable freezing capacity, logistics, less income). It is expected the market of frozen potato products will increase by $20 \%$ per year. But surely the processing companies should keep track of the demographic evolution, household trends, and incomes per cluster in the coming years and determine which clusters provide the best chances for them.

Looking to frozen potato products QSR's and star restaurants are important channels to sell French fries and some specialties. Supermarkets are an important channel to sell specialties for home consumption. Beside regular potato products Indian consumers also prefer Indian taste potatoes products.

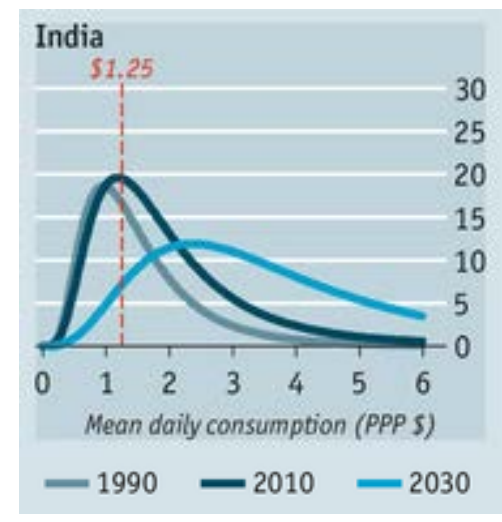

Figure 3.9 Number of people in poverty (m) (Anonymous 2013).

\subsection{Food trends}

\subsubsection{General Indian food consumption trends and habits}

The younger and growing middle class population will increasingly eat outdoors and spent more of their income on out-door meals. This is also due to the fact that more women are joining the workforce and thus have less time at home to prepare meals. Also men from rural areas who work and live in cities during weekdays take less time to prepare their own meals and prefer fast food.

And although the common perception in India is that frozen food is for people who have no time to cook, and that it is perceived to be unhealthy, not as tasty as home-cooked food and not a replacement for the home-cooked meals, it is probable that also the in-home market for frozen food products will increase. Especially snacks like smiles are popular to consume at home by children. This because of time constraints in the household, coupled by the fact that consumers are more exposed to western lifestyles. There will be more experimentation with new dietary habits and higher protein consumption (instead of carbon hydrates).

Also from the Euromonitor Packaged Food in India (2015b) it appears that packaged food was subject to growth in value and volume in 2014. They relate this growth directly to the increasingly hectic pace of modern life and rising annual disposable incomes, as consumers shift towards convenient and easy to eat packaged foods.

It also appears that places like Quick Service Restaurants (QSR's) are places to experience the novelty of eating out in a western setting and out-door French fries consumption (or other processed potato snacks, like vegetarian burgers or veggie-nuggets) is on the rise. In this report it is also indicated that modern middle upper class families prefer service and safe food of high quality, and they prefer to buy 
A-brands in closed packaging. Additionally it appears that they also prefer to eat in the same standardised food (QSR) outlets (source: verbal communication); each QSR branch has the same food preparation formula and product range and these families who put food safety first are keen on this. Especially when they are on the road for holidays (or work travels) they opt for safe food. This is why the QSR companies also focus on the realization of outlets at food corners on the highways between the major cities.

With regard to regional characteristics it is worth mentioning that in each geographical region in India different traditional spices are used. Food companies anticipate on this by processing all kinds of different food varieties, targeting on different regional markets. Producers of the potato-based (veggie) specialties are doing the same.

\subsection{Sales channels of frozen potato products}

\subsubsection{The retail market}

General shopping preferences and trends:

- Unorganized retail will continue to offer much convenience to the consumer. From a study of the Indian Council for Research on International Economic Relations (ICRIER) (Winter 2008) it appeared that India had a total of estimated 13 million so called unorganized retailers at that time. 'Unorganized' stores are 'single stores' without links to other stores. Kirana stores (selling bakery products, dairy and processed food, home and personal care, and beverages, cereals, pulses, spices, and edible oils) are among the unorganized stores. These traditional Kirana retail outlets offer much convenience to the consumer, because there is one at almost every street corner.

\begin{tabular}{|c|c|c|}
\hline \multicolumn{3}{|l|}{ What's in store? } \\
\hline Company & $\begin{array}{l}\text { Food \& grocery } \\
\text { formats }\end{array}$ & $\begin{array}{l}\text { Number } \\
\text { of stores }\end{array}$ \\
\hline Reliance Industries & Reliance Fresh & 550 \\
\hline Future Group & $\begin{array}{l}\text { Big Bazaar; Food } \\
\text { Bazaar; foodhall; } \\
\text { KB's Fairprice }\end{array}$ & 530 \\
\hline Aditya Birla Group & More & 504 \\
\hline REI Agro Ltd & 6Ten & 344 \\
\hline BhartiGroup & Easyday & 210 \\
\hline RP-Sanjiv Goenka Group & Spencer's & 135 \\
\hline Avenue Supermarkets & D-Mart & 79 \\
\hline Godrej Group & Nature's Basket & 32 \\
\hline Tata Sons & Star Bazaar & 11 \\
\hline
\end{tabular}

Figure 3.10 Modern retail brand names and their number of stores (Anonymous 2014).

- $\quad$ Organized or modern retail is forming a substantial part of the total retail sector. Organized or modern retail has chain stores which are owned or franchised by a central entity. The study of ICRIER (Winter 2008) assumed that the modern retail sector was growing at a pace of $45-50 \%$ per year. The players and the number of stores within the modern retail sector appeared to be the following (Figure 3.10) in 2014. Also from a research article of Singh (2014) it appears that the author estimates the relative share of the traditional retail was $96 \%$, leaving that of organized retail $4 \%$, in 2009 . The relative share of the organized retail is expected to increase to $76 \%$ by 2020 (leaving 24\% for the unorganized retail). The author says that India's retail sector is heading towards modernization and that new formats such as departmental stores, supermarkets and speciality stores, Westernised malls are fast appearing in metros and tier-II cities. 
- $\quad$ An article in The Economist (Anonymous 2014) shows that frequent purchases (daily or every two or three day-products) are mostly done from the traditional stores, according to research by the Boston Consulting Group (BCG). Less regular purchases (like packaged foods; soaps, detergents and other groceries; and staples, such as rice and grains) are mostly done from modern supermarkets. Rich consumers mostly buy from the modern supermarkets as well (Figure 3.11). But the research shows that in general even wealthy consumers prefer traditional stores for reasons such as vicinity, broader opening hours and credit facilities.

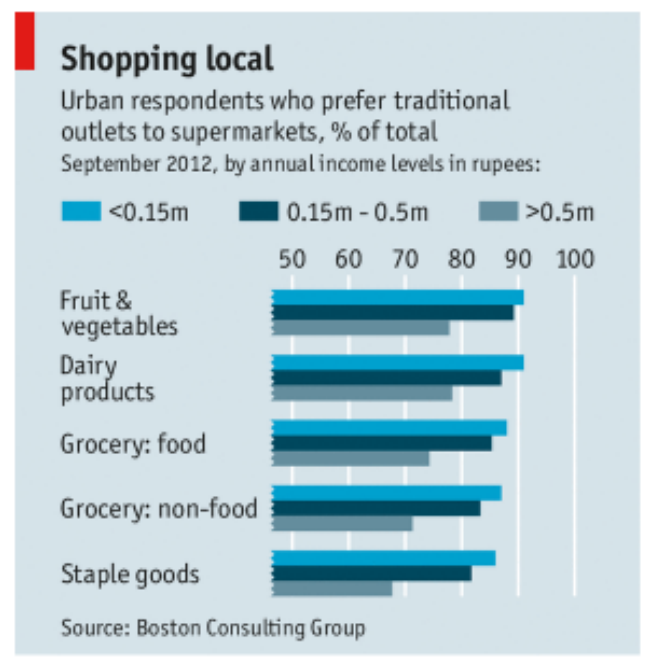

Figure 3.11 Urban respondents who prefer traditional outlets to supermarkets according to income level (Anonymous 2014).

- $\quad$ Growing demand for retail; traditional and modern retail will benefit both.

The study of ICRIER (Winter 2008) indicates that the growth of modern retail will be not at the cost of the traditional retailers.

- $\quad$ Consumers will be more experimenting in the future.

From a consumer research by the Nielsen White Paper (2012) it appears that 36 percent of shoppers reported shopping at more than two stores during the month in 2011, compared to 20 percent just one year earlier. So the Kirana store will no longer be the only shop for the consumers purchases. The Nielsen White Paper (2012) also points out that the Indian consumer will be more demanding of retail in terms of modernization and that he or she is more and more actively seeking for promotions.

- $\quad$ Online shopping is picking up in India, so modern stores as well as the upgraded Kirana stores would do well to adopt various digital payment techniques, get online and optimize their ability to home deliver quick and flexible.

- $\quad$ The market for potato specialties will grow very fast, especially when the in-home consumption is growing due to increased promotion and marketing campaigns and actions by the big companies (verbal communications).

- $\quad$ For processors of frozen potato products it is of great importance that the vegetarian potato product market can optimally be developed as this segment shows a higher valorisation rate than French fries.

\subsubsection{The QSR market}

India's fast food market is expected to grow by $25 \%$ per year, as result of changing consumer preferences and the largest youth population of the world. At city level, a large share of the QSR market rests in metros and mini metros due to higher consumption, heightened consumer awareness, and exposure in key cities such as Delhi, Mumbai, and Bangalore. Slowly, QSRs have established their foothold in the major cities and are now expanding into smaller cities with smaller formats. Changing lifestyles, a younger workforce with higher disposable incomes and better standards of living have stimulated the growth of QSRs. There are two types of QSR's in India: Indian brand QSR (Haldirams, 
Kailash Parbat, Jumboking, etc.) and foreign brand QSR (international chains like McDonalds, KFC, Domino's, and Pizzahut). Ethnic food is offered by Yo China, Tibbs Frankie and Falafels.

Indian QSR's focus on Indian foods and multiple cuisines, which contrast the international players' focusing on a single cuisine or product category. In terms on menu Indian players have a skew to vegetarian food in contrast to international players who offer a mix of vegetarian and non-vegetarian foods.

Many global players in the QSR segment such as Dominos, Mc Donald's and KFC have expanded their reach to the small cities in India and thus have managed to increase the footfall in their outlets. Further, the QSR's in India have their presence in different formats such as dine-in, food courts in malls and drive-ins in highways which has provided the customers an easy access to these restaurants. Apart from the global players, many of the domestic players in India such as Nirula's and Kaati Zone have also attracted the eating out population in India by offering quick service at affordable prices. QSR visitors indicate that taste, hygiene, quality, service and price influence their decision to visit QSR's instead of a street food vendor. Consumers demand more and more information related to hygiene issues and nutritional values of the products of fast food outlets. It can be concluded that with more and more acceptability of fast food outlets and change in life style, competition among fast food outlets with respect to quality of food and customer service will be more prominent in the days to come.

\subsubsection{Concluding remarks}

For the in-home consumer market of frozen food products the trend that packaged food is on the rise can be favourable. For the out-of-home market the fact that modern middle upper class families prefer service and safe food of high quality, coupled by the fact that this is the social group that tends to travel frequently by car, offers opportunities for QSR companies to sell frozen food products also at outlets on the highways between the major cities.

And taking the above mentioned shopping trends in consideration, companies within the frozen potato products market should better start market penetration at modern supermarkets than at Kirana stores. The Kirana stores with small refrigeration facilities (for all kind of frozen products) are very less in number, especially in rural areas. This currently poses a big hurdle for the frozen food market. Also lack of knowledge by store owners how to handle frozen products is a shortcoming. Restricted freezer space and uncertain electricity supply also constrains further growth. All in all freezers require a fair amount of monetary investment and moreover, 24 hours supply of electricity as well.

Potato processors not only focus on the QSR market but they intend that they want be a part of every household's food basket in India. McCain's target would be to have $100 \%$ presence in modern trade shops, which have freezer reliability. They aim to educate shop owners about the need for freezers.

\subsection{Obstacles hampering the development of the frozen potato product market and SWOT analysis}

\subsubsection{Lack of cold chain facilities}

Three different obstacles concerning the low presence of cold chain facilities within the retail segment as well as within the distribution segment can be distinguished. The first is related to the low investment capacity within the retail sector (1); the second being related to consumer desires (2); the third is related to infrastructure facilities and the transportation sector in general (3).

1. It has become clear from the previous paragraph that although the retail sector is evolving, it is still dominated by the unorganized retail. From an article on the Progressive Grocer website (Sharma 2014), it appears that this unorganized retail sector is traditionally characterised by low investment. It is indicated that the stores with refrigeration facilities are very less in number and that this is a major roadblock for increasing penetration of frozen food through general trade 
(Sharma 2014).

To illustrate the low penetration rate of refrigerators in India's rural area some figures of some durables in urban and rural areas are given in Table 3.3 (figures published in 2014).

Table 3.3.

Penetration rate of some durables in urban and rural areas (Kumar \& Dangi 2013).

\begin{tabular}{lccc}
\hline Durables & Urban & Rural & Total ( \% of Rural HH) \\
CTV (television) & 30.4 & 4.8 & 12.1 \\
\hline Refrigerator & 33.5 & 3.5 & 12.0 \\
\hline
\end{tabular}

2. It appears that the frozen food category is currently non-existent in rural areas but that rural consumers may aspire for such foods (Sharma 2014). So even if there might be a consumer demand for frozen potato products (also rural people may be willing to experiment with new foods) this demand cannot yet be satisfied.

3. Infrastructure facilities like cold storage and temperature controlled (cold) transport is generally lacking in the country (Sharma 2014).

Mittal (2013) indicates that an efficient cold chain requires a good working transportation system to transport frozen products in the stipulated time-frame while maintaining the required temperature. This is hardly the case in India. Mittal mentions that there are very few specialized distribution companies providing refrigerated transport and warehousing for processed food products. Also the space for refrigerators is lacking at the distributors end. He attributes this to the fact that there is a low adoption of cold chain facilities because of high costs and little knowledge of technical skills to conceptualize and execute. According to Mittal this results in few players operating in this segment.

\subsubsection{Unreliable electricity supply}

In India, the demand for electricity has always been more than the supply. Main problems are: short of equipment and unstable power supply. The unreliable power supply situation is a big hurdle for the market penetration of frozen food products. In almost all states in India the electricity supply is not secured. It is the rule rather than the exception that there is power supply only during 4 hours per day, and in the rural areas the situation can be even worse. Indian power sector has made considerable progress in the last decade and has evolved from a nascent market to a developing market led by policy reforms and increased private sector participation.

For companies like McCain cold storage, and thus electricity, is mandatory both during distribution and end point retail. 
Table 3.4

SWOT analysis of the frozen potato product market in India

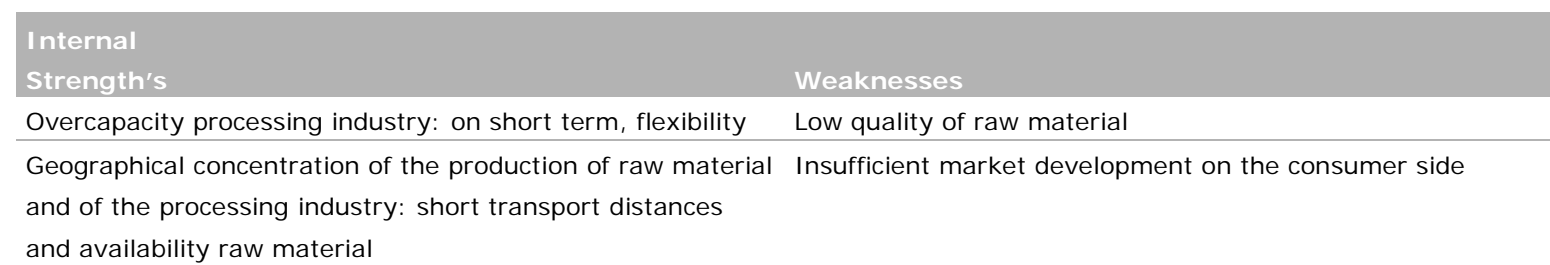

and availability raw material

Poor logistics frozen products (especially end chain)

Weak end-chain cooling facilities: reliable freezing capacity

Lack of freezing knowledge by shop owners

Little modernity and a lot of hand work within the potato chain: handling in bags

\begin{tabular}{|c|c|}
\hline External & \\
\hline Opportunities & Threats \\
\hline The frozen food market is still a niche market & Unreliable power supply \\
\hline result of increasing incomes and modern lifestyle & \\
\hline Increasing incomes, especially in cities and urban regions & Little technical knowledge to adopt cold chain facilities at the \\
\hline
\end{tabular}

Adopting of the Western life style: growing popularity of fast Public health issues: e.g. obesities

food, especially by young people

The rich Indian kitchen: development of many different Infrastructure

flavours and vegetarian products for a broad public within

the QSR segment and the retail segment (development of

specialties for in-home consumption).

At home consumption: specialties, children

Unawareness of cold storage as a method of preservation at super market employees and consumers

Cheap labour

Food safety

\subsubsection{How is the market expected to be dealing with the obstacles?}

Frozen food market penetration in any country is fully dependent on the infrastructure, cold chain management and cold chain facilities, like hubs with cold storage ware houses, frozen transport, the presence of freezers in outlets, and 24-hours power supply. Besides, the success also depends on (increasing) consumer demand.

For the Indian situation this means that there are still a few hurdles to overcome in order for the production companies to utilize their full production capacity. For manufacturers of potato products, also a limitation lies in product marketing: consumers cannot be forced to consume frozen potato products. This is a process that needs time to develop.

Dealing with the low investment capacity within the traditional retail sector As refrigeration facilities are present in modern retail stores (in metropolitan areas), and these stores attract the segment of consumers looking for convenience food such as ready to cook/eat products, the modern trade is currently the only and preferred channel of sales for frozen food category. It is expected that this will continue to be the case for the coming 10 years. Also freeze capacity at home is still modest but will increase in future. We found new freezers varying in price from INR 10,000 (simple) - 100,000 (American style).

Dealing with the lack of infrastructure facilities like cold storage and temperature controlled (cold) transport

Processors of frozen potato products indicate that there are hardly any storage problems on transports from the factory to the first hub. Processors indicate problems increase in the second half of the frozen chain (transports and storage between second and third hub and retail stores) where their influence is 
less. Knowledge of logistic partners and retail organisations on handling, storage and display of frozen products should be improved. Processors should cooperate with logistic partners and retailers.

Dealing with the unreliable power supply situation

Electric energy consumption in agriculture was recorded highest (18.45\%) in 2014-15 among all countries (Government of India 2015). In order to address the lack of adequate electricity availability to all the people in the country by the platinum jubilee (2022) year of India's independence, the Government of India has launched a scheme called "Power for All" which will ensure that there is 24/7 continuous electricity supply provided to all households, industries and commercial establishments by creating and improving necessary infrastructure. It's a joint collaboration of centre with states to share funding and create overall economic growth. Currently nine states have joined the scheme.

\subsection{Small packaging of fresh potatoes: is this feasible?}

Outside the scope of the market research of the frozen potato products in the previous paragraphs, the researchers also have looked at the question whether the small packaging of fresh potatoes is possible and feasible in India.

\subsubsection{Overview of the fresh vegetable market}

Ninety percent of all potatoes produced in India is sold as a fresh vegetable and used as ingredient for several Indian dishes. Consumers prefer medium sized potatoes. Most potatoes are sold as loose product on small markets, by vendors or in supermarkets. Beside loose potatoes supermarkets also sell small 1-, 3- or 5-kg packages in nets. There is no product information, like variety or origin, given on the nets. In supermarkets in Ahmedabad loose unpacked potatoes ( $€$ 0.19/15 INR per kg) are seen and potatoes in 1- and 5-kg nets without any information ( $€$ 0.225/INR 18 per kg; September 2015). Most supermarkets only sell one variety, so consumers don't have any choice.

Looking at the potato supply, consumers are at the mercy of traders and supermarkets. It is expected that the power of supermarkets in the vegetable chain will increase in the future and that supermarkets will increase selling potatoes directly from storage holders or wholesalers. Consumers don't have much knowledge of potatoes.

A new development is that supermarkets buy potatoes on contract directly from cold stores. The advantages are:

- Short chain

- No price violation

- Better control

Middle man have a strong position and key role in the Indian market of fresh potatoes. Due to recent legal decisions the position of the middle men is no longer protected. This means that the market of middle men is no longer protected and everybody can start as middleman. Therefore it is estimated that the position of middleman will change in the near future.

\subsubsection{Packaging}

For introducing packaging the following items have to be studied:

- Type of packaging, taking into account the Indian climate.

- Looking at the Indian cooking and food habits; what will be the information consumers should know? (knowledge about potatoes)

- What will be the right way to inform Indian consumers? 
The government doesn't support cost-increasing activities like packaging: the aim of the Indian government is to keep consumer prices of food low. And since Indian consumers have hardly any knowledge about potatoes (for example about cooking types, varieties, etc.; see annual report 2014) this means that stakeholders have to take initiatives. 


\section{$4 \quad$ Storage experiments}

Lubbert van den Brink, Wageningen University \& Research, Wageningen, The Netherlands

\subsection{Preliminary studies on cold storage, 2015}

\subsubsection{Real Cold Store}

\subsubsection{Introduction}

In 2015, a storage experiment was conducted in the Real Cold Store in Himmatnagar. In this store potatoes owned by McCain were stored. The store consisted of four chambers and potatoes were stored in netted bags of $50 \mathrm{~kg}$. Two chambers were upgraded by Mooij and other two were traditional chambers. In each chamber, potatoes were stored on five floors. The storage capacity of the store was ca. 7.500 ton, 2.250 ton in each upgraded chamber and 1.500 ton in each traditional chamber.

The aim of the experiment was:

- To compare upgraded and traditional chambers with respect to weight losses and quality of stored potatoes,

- To test uniformity of storage conditions within upgraded and traditional chambers.

The experiment was done by McCain and WUR.

\subsubsection{Methods}

On 2 March, 126 samples were taken from an uniform potato lot, harvested under good conditions from one homogeneous field. The variety was Innovator.

Each sample had a size of $\pm 10 \mathrm{~kg}$. Healthy potatoes were chosen and each sample was put in a netted bag. Exact weight of each sample was determined just before putting the sample in the store. The samples were labelled in a way that weight losses could be measured for each individual sample. On 2 March, 60 samples were put in chamber 1 (upgraded by Mooij). On each floor two temperature sensors were available for recording product temperature. On each location in the chamber where product temperature was recorded six samples were stored. At the moment of putting the samples in the chamber, the whole chamber was already loaded with potatoes in $50 \mathrm{~kg}$ netted bags. These bags were stored in stacks, with a height of eight layers of bags. Samples were put at the top of the stacks, just between bag layer 7 and bag layer 8 .

On 3 March, 60 samples were put in chamber 3 (traditional). Also in this chamber temperature sensors were recording product temperature on two locations on each floor. On each location, samples were stored in the same way as in chamber 1.

On 3 March, store loading process with bags of $50 \mathrm{~kg}$ potatoes was still going on in chamber 3 . In one stack six samples were put on different locations: three samples between bag layer 3 and 4 (one in the middle of the stack and the other two $2.5 \mathrm{~m}$ to the right or to the left of the middle of the stack) and three samples between layer 6 and 7 (one in the middle of the stack and the other two $1.5 \mathrm{~m}$ to the right or to the left of the middle of the stack). A wireless temperature sensor was attached to each of these samples. Figure 4.2 presents a schematic overview of the locations of storing a sample in the stack. 


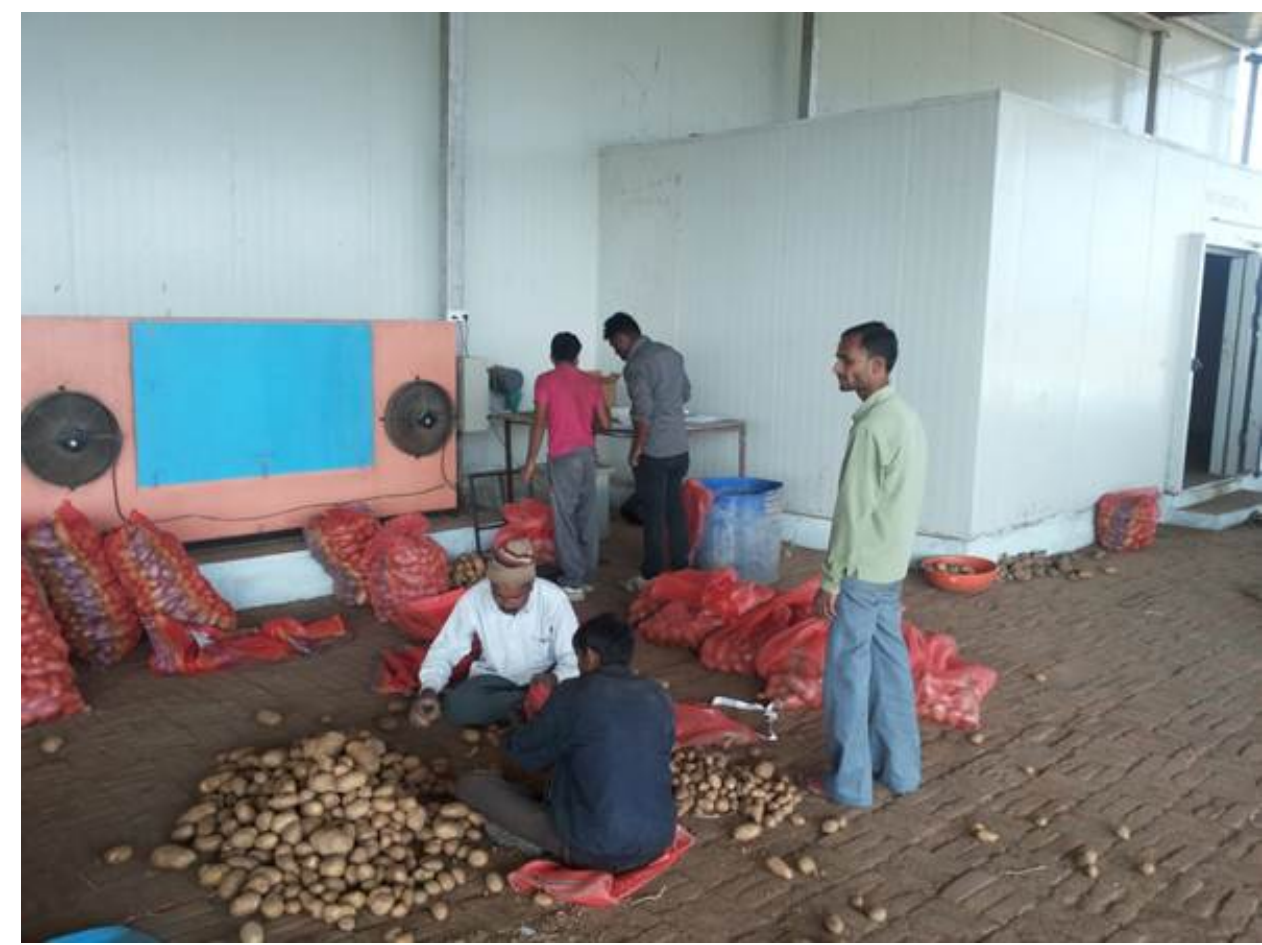

Figure 4.1 Preparing samples.

On 3 March, store loading process with bags of $50 \mathrm{~kg}$ potatoes was still going on in chamber 3 . In one stack six samples were put on different locations: three samples between bag layer 3 and 4 (one in the middle of the stack and the other two $2.5 \mathrm{~m}$ to the right or to the left of the middle of the stack) and three samples between layer 6 and 7 (one in the middle of the stack and the other two $1.5 \mathrm{~m}$ to the right or to the left of the middle of the stack). A wireless temperature sensor was attached to each of these samples. Figure 4.2 presents a schematic overview of the locations of storing a sample in the stack.

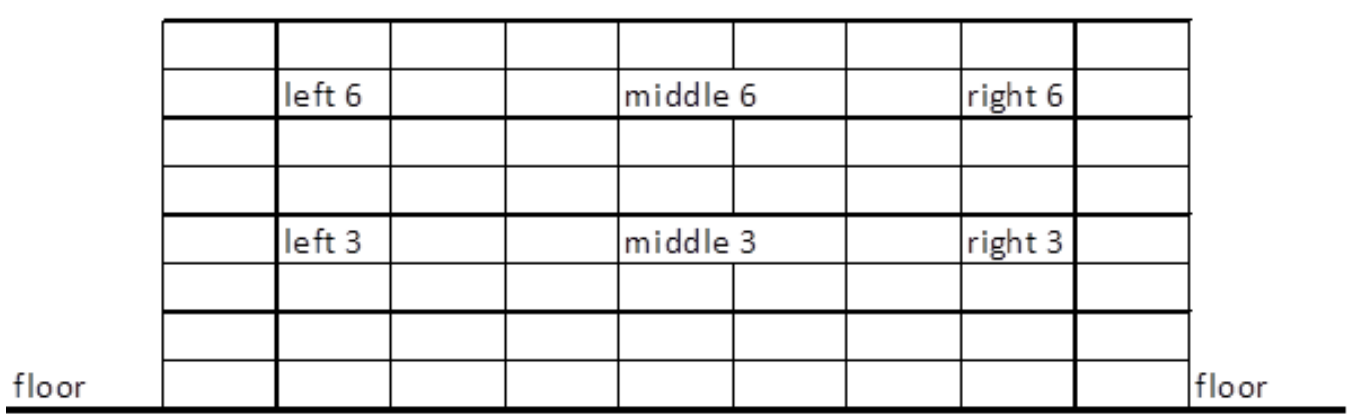

Figure 4.2 Schematic overview of locations within a stack where a sample with a wireless temperature sensor was stored.

On 13 March, again 126 samples were taken from another uniform potato lot, harvested under good conditions from one homogeneous field grown with the variety Innovator. Samples were made in the same way as on 2 March.

On 13 March, 60 samples were put in chamber 2 (upgraded by Mooij). On each floor two temperature sensors were available for recording product temperature. On each location in the chamber where product temperature was recorded six samples were stored in the same way as in chambers 1 and 3 . On 13 March, the store loading process was still going on in chamber 2. In one stack six samples were put on different locations: three samples between bag layer 3 and 4 (one in the middle of the stack and the other two $2.5 \mathrm{~m}$ to the right or to the left of the middle of the stack) and three samples between layer 6 and 7 (one in the middle of the stack and the other two $1.5 \mathrm{~m}$ to the right or to the left of the middle of the stack). A wireless temperature sensor was attached to each of these samples. 
On 27 March, 60 samples were put in chamber 4 (traditional). Also in this chamber temperature sensors were measuring product temperature on two locations on each floor. On each location, samples were stored in the same way as in the other chambers.

During storage period, samples were taken from the store at different moments: 1 May, 22 June, 4 August, 15 September and 17 November. Each time one sample was taken from each location. At the store, total weight (including bag and label) immediately after leaving the store was assessed. At the laboratory, total weight was assessed again. Potatoes were split up in two parts:

1. Healthy tubers and healthy parts of tubers with less than $25 \%$ rot;

2. Rotten tubers (criteria: more than $25 \%$ rot) and rotten parts of tubers with less than $25 \%$ rot (residues were added to rotten tubers).

The weight of the healthy tubers and the weight of the rotten tubers was assessed. From each sample 20 tubers were taken for the assessment of frying quality. Frying quality was assessed according to the method of McCain.

In the beginning of August the two traditional chambers ( 3 and 4) were unloaded. On 15 September it was possible to take samples from the two upgraded chambers ( 1 and 2), but not from the traditional chambers. On 17 November it was only possible to take samples from one of the upgraded chambers (chamber 2).

\subsubsection{Results}

Table 4.1 presents for each chamber mean percentages of losses due to loss of water and respiration at different moments. Also minimum and maximum percentages are given.

\section{Table 4.1}

Percentage of losses due to loss of water and respiration. Mean of 10 samples per chamber. (Between brackets variation between samples: minimum and maximum \%)

\begin{tabular}{|c|c|c|c|c|c|c|c|}
\hline \multirow{3}{*}{$\begin{array}{l}\mathrm{Ch} \\
1\end{array}$} & \multirow{3}{*}{$\begin{array}{l}\text { Sys } \\
\text { tem }{ }^{1} \\
\text { U }\end{array}$} & \multirow{3}{*}{$\begin{array}{l}\text { Start } \\
2 \text { March }\end{array}$} & \multicolumn{5}{|c|}{ Moment of analysing } \\
\hline & & & 01-May & 22-J un & 04-Aug & 15-Sep & \multirow{2}{*}{$\begin{array}{l}\text { 17-Nov } \\
-\end{array}$} \\
\hline & & & $2.7 \quad(0.9-4.8)$ & $3.2 \quad(2.3-4.0)$ & $4.6 \quad(3.5-8.2)$ & $5.3 \quad(3.4-7.3)$ & \\
\hline 3 & $\mathrm{~T}$ & 3 March & $2.6 \quad(2.2-2.9)$ & $3.4 \quad(2.7-4.2)$ & $5.7 \quad(4.2-9.0)$ & - & - \\
\hline 2 & U & 13 March & $4.3 \quad(2.4-8.5)$ & $4.2 \quad(3.0-9.0)$ & $5.4 \quad(2.4-9.5)$ & $5.9 \quad(4.1-8.8)$ & $12.4 \quad(7.2-17.9)$ \\
\hline 4 & $\mathrm{~T}$ & 27 March & $2.1 \quad(1.5-2.4)$ & $3.2 \quad(2.1-4.50$ & $7.5 \quad(4.3-10.3)$ & - & - \\
\hline
\end{tabular}

${ }^{1} \mathrm{U}=$ upgraded; $\mathrm{T}=$ traditional

\section{Table 4.2}

Percentage of losses due to rot. Mean of 10 samples per chamber. (Between brackets variation between samples: minimum and maximum \%).

\begin{tabular}{|c|c|c|c|c|c|c|c|c|c|c|c|}
\hline \multirow{2}{*}{$\begin{array}{l}\text { Ch } \\
1\end{array}$} & \multirow{2}{*}{$\begin{array}{l}\text { Sys } \\
\text { tem }{ }^{1} \\
\mathrm{U}\end{array}$} & \multirow{2}{*}{$\begin{array}{l}\text { Start } \\
2 \text { March }\end{array}$} & \multicolumn{9}{|c|}{ Moment of analysing } \\
\hline & & & 2.9 & $(0.6-7.4)$ & 3.2 & $(2.3-4.0)$ & 4.6 & $(3.5-8.2)$ & 9.6 & $(0.0-23.6)$ & $\begin{array}{l}17-N o v \\
-\end{array}$ \\
\hline 2 & $\mathrm{U}$ & 13 March & 1.9 & $(0.0-6.7)$ & 4.2 & $(3.0-9.0)$ & 5.4 & $(2.4-9.5)$ & 10.5 & $(2.0-17.6)$ & $(1.0-9.9)$ \\
\hline 4 & $\mathrm{~T}$ & 27 March & 1.8 & $(0.2-4.0)$ & 3.2 & $(2.1-4.50$ & 7.5 & $(4.3-10.3)$ & - & & - \\
\hline
\end{tabular}

${ }^{1} \mathrm{U}=$ upgraded; $\mathrm{T}=$ traditional

Table 4.2 presents for each chamber mean percentages of losses due to rot at different moments. 
Table 4.3.

Storage efficiency (weight of processing potatoes in \% of initial weight). Mean of 10 samples per chamber. (Between brackets variation between samples: minimum and maximum \%).

\begin{tabular}{|c|c|c|c|c|c|c|c|c|c|c|c|}
\hline \multirow{3}{*}{$\begin{array}{l}\text { Ch nr } \\
1\end{array}$} & \multirow{3}{*}{$\begin{array}{l}\text { Sys } \\
\text { tem }^{1} \\
\mathrm{U}\end{array}$} & \multirow{3}{*}{2 March } & \multicolumn{9}{|c|}{ Moment of analysing } \\
\hline & & & \multicolumn{2}{|c|}{ 01-May } & \multicolumn{2}{|c|}{ 22-J un } & \multicolumn{2}{|c|}{ 04-Aug } & \multicolumn{2}{|c|}{ 15-Sep } & \multirow{2}{*}{$\begin{array}{l}17-\mathrm{Nov} \\
-\end{array}$} \\
\hline & & & 94.5 & $(88.1-97.7)$ & 88.7 & $(76.0-94.4)$ & 90.0 & $(80.3-95.4)$ & 85.6 & $(70.8-96.5)$ & \\
\hline 3 & $\mathrm{~T}$ & 3 March & 95.1 & $(92.6-97.2)$ & 91.2 & $(86.9-94.8)$ & 86.4 & $(78.0-94.1)$ & - & & - \\
\hline 2 & $\mathrm{U}$ & 13 March & 93.9 & $(85.3-97.6)$ & 89.6 & $(74.7-94.3)$ & 88.1 & $(84.2-95.0)$ & 84.2 & $(75.7-94.0)$ & $5.1 \quad(76.2-91.9)$ \\
\hline 4 & $\mathrm{~T}$ & 27 March & 96.1 & $(93.8-98.3)$ & 91.4 & $(84.2-95.8)$ & 87.1 & $(82.0-94.3)$ & - & & - \\
\hline
\end{tabular}

${ }^{1} \mathrm{U}=$ upgraded; $\mathrm{T}=$ traditional

Table 4.3 presents for each chamber the mean storage efficiency (weight of healthy potatoes as percentage of the initial weight).

Table 4.4.

Fry index values. Mean of 10 samples per chamber.

\begin{tabular}{|c|c|c|c|c|c|c|c|}
\hline $\begin{array}{l}\mathrm{Ch} \\
\mathrm{nr}\end{array}$ & $\begin{array}{l}\text { Sys } \\
\text { tem }{ }^{1}\end{array}$ & Start & \multicolumn{5}{|c|}{ Moment of analysing } \\
\hline 1 & $U$ & 2 March & 1.1 & 1.1 & 1.0 & 1.1 & - \\
\hline 2 & 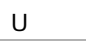 & 13 March & 1.1 & 1.1 & 1.1 & $1.1^{2}$ & $1.7^{3}$ \\
\hline 4 & $\mathrm{~T}$ & 27 March & 1.0 & 1.0 & 1.0 & - & - \\
\hline
\end{tabular}

${ }^{1} \mathrm{U}=$ upgraded; $\mathrm{T}=$ traditional

2 One sample (total number of samples $=10$ ) with 1 stick in class 3 and 1 stick in class 4 (out of 20)

${ }^{3}$ Three samples (total number of samples $=10$ ) with more than 2 sticks in class 3 or 4 (out of 20)

Table 4.4 presents for each chamber mean fry index values. Variation between samples was very small. Only at the last sampling moments (15 September and 17 November) some samples had relative high values.
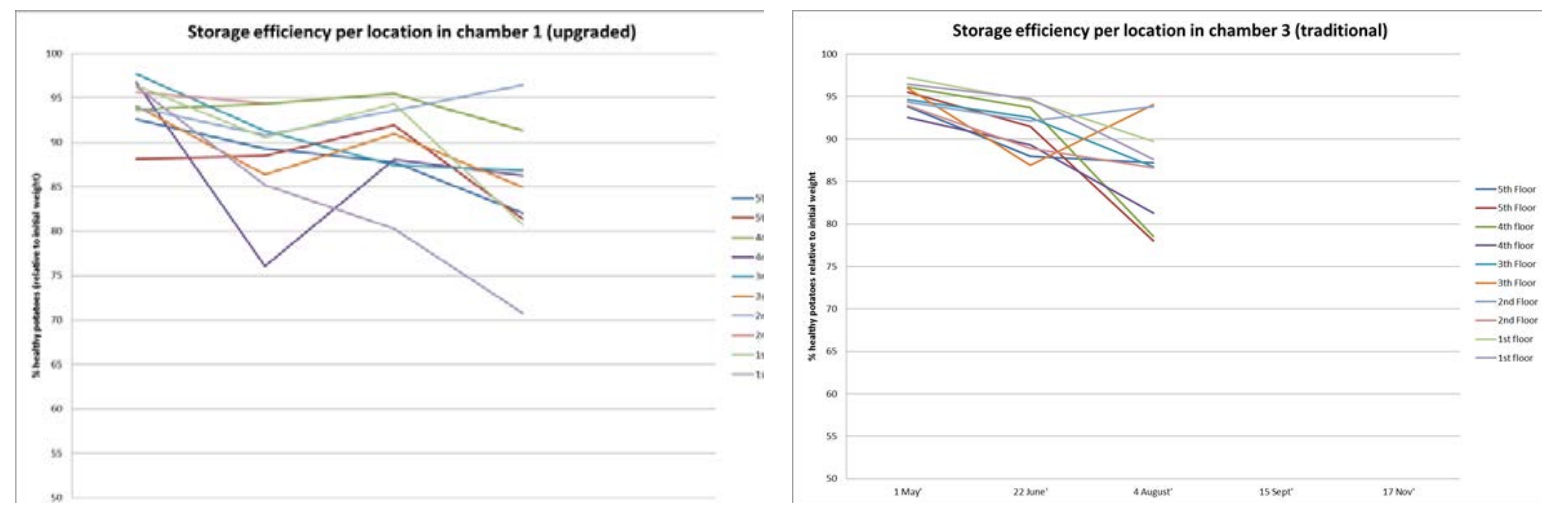

Figure 4.3 Storage efficiency (healthy potatoes in \% of initial weight) per location in chamber 1 (upgraded; loading moment 2 March, left) and chamber 3 (traditional; loading moment 3 March, right).

Figure 4.3 and Figure 4.4 present storage efficiency per location in the different chambers. At each moment one sample per location was analysed. 

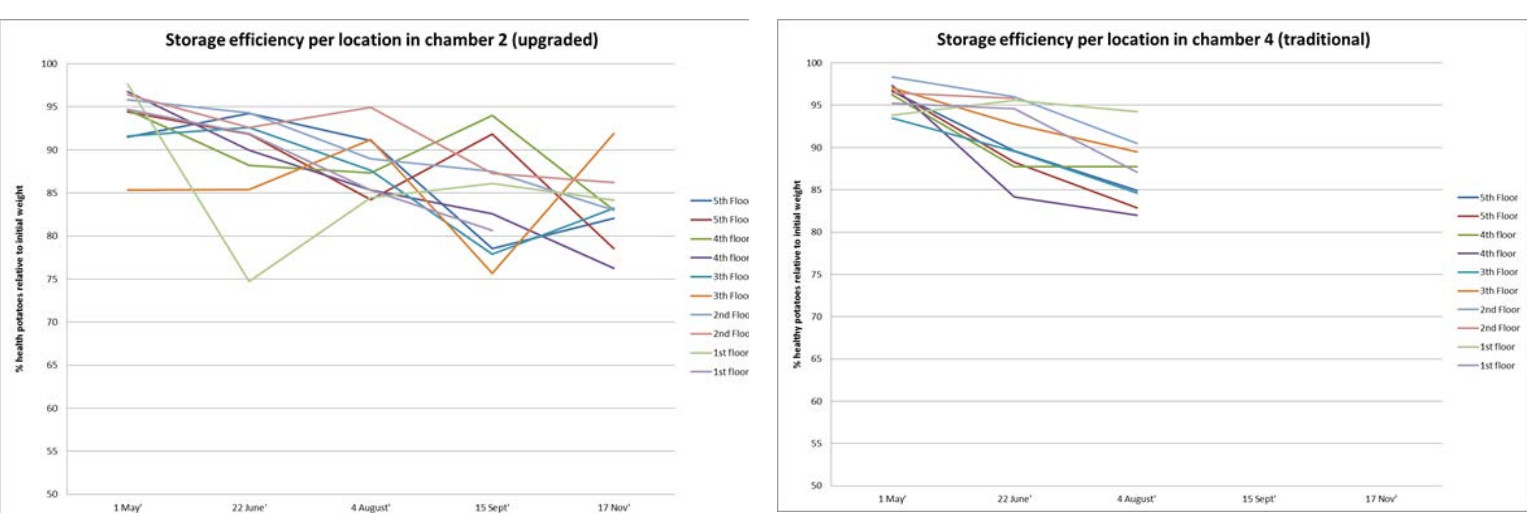

Figure 4.4 Storage efficiency (healthy potatoes in \% of initial weight) per location in chamber 2 (upgraded; loading moment 13 March, left) and chamber 4 (traditional; loading moment 27 March).

\section{Table 4.5}

Water plus respiration losses (\%) and losses due to rot (\%), and storage efficiency of samples stored at different locations within a stack on the fifth floor.

\begin{tabular}{|c|c|c|c|c|c|c|}
\hline & \multicolumn{3}{|c|}{$\begin{array}{c}\text { Chamber 3, traditional; start } 3 \\
\text { March, analysed } 4 \text { Aug } \\
\end{array}$} & \multicolumn{3}{|c|}{$\begin{array}{c}\text { Chamber 2, upgraded; start } 13 \text { March, } \\
\text { analysed } 17 \text { Nov. }\end{array}$} \\
\hline & $\begin{array}{l}\text { water plus } \\
\text { respiration }\end{array}$ & rot & $\begin{array}{l}\text { storage } \\
\text { efficiency }\end{array}$ & $\begin{array}{l}\text { water plus } \\
\text { respiration }\end{array}$ & rot & $\begin{array}{l}\text { storage } \\
\text { efficiency }\end{array}$ \\
\hline Between $3^{\text {rd }}$ and $4^{\text {th }}$ layer left & 3.7 & 6.9 & 89.7 & 11.2 & 4.9 & 84.4 \\
\hline Between $3^{\text {rd }}$ and $4^{\text {th }}$ layer mid & 4.6 & 4.4 & 91.2 & 12.9 & 2.3 & 85.1 \\
\hline Between $3^{\text {rd }}$ and $4^{\text {th }}$ layer right & 4.9 & 1.9 & 93.2 & - & - & - \\
\hline Between $6^{\text {th }}$ and $7^{\text {th }}$ layer left & 3.8 & 5.2 & 91.2 & 11.7 & 8.7 & 80.6 \\
\hline Between $6^{\text {th }}$ and $7^{\text {th }}$ layer middle & 4.1 & 4.1 & 91.9 & 11.9 & 7.8 & 81.3 \\
\hline Between $6^{\text {th }}$ and $7^{\text {th }}$ layer right & 3.9 & 2.9 & 93.2 & 7.7 & 2 & 90.4 \\
\hline
\end{tabular}

$1 \%$ healthy potatoes relative to initial weight

Table 4.5 presents percentages of losses due to water loss and respiration, losses due to rot and storage efficiency of samples stored at different locations within a stack in the traditional chamber (3) and in the upgraded chamber.
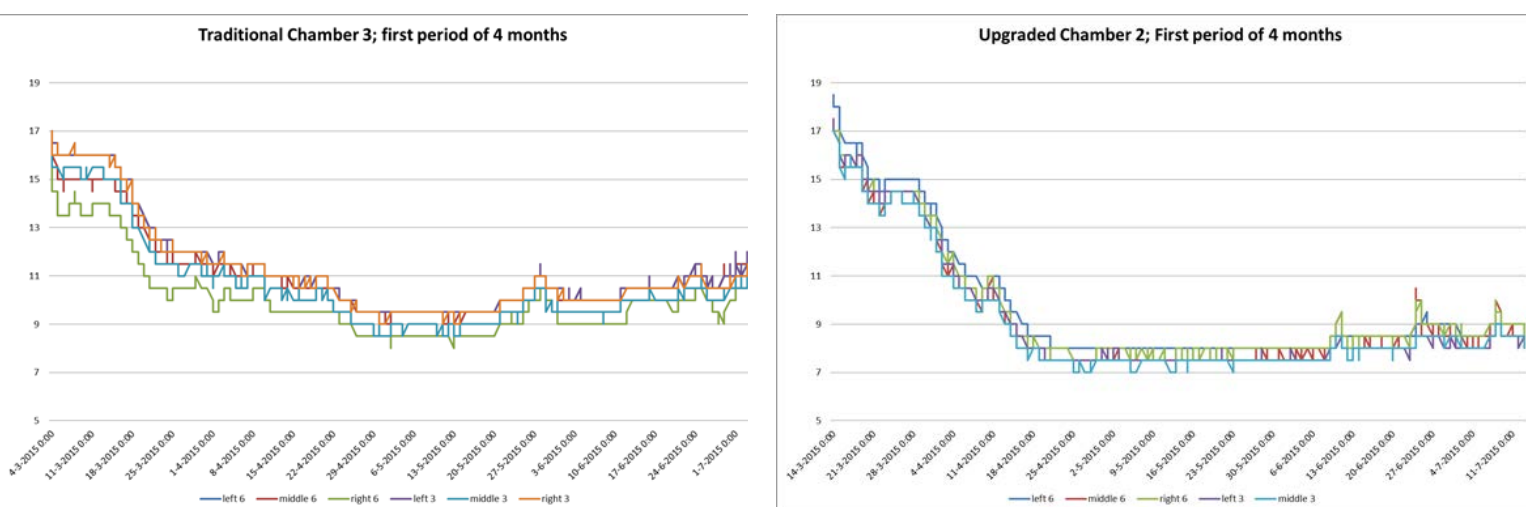

Figure 4.5 Temperature at 6 locations within a stack in the traditional chamber (left); Temperature at 5 locations within a stack in the upgraded chamber (location "right 3" was lost). For locations see Figure 4.1.

Figure 4.5 presents temperatures at different moments in the different samples in the traditional chamber (chamber 3, left) and in the upgraded chamber (chamber 2, right). In both figures temperature is presented for the first four months after the moment of putting samples in the store. 


\subsubsection{Discussion}

Storage losses were relatively high, on average going up to more than $15 \%$ on 15 September. Most losses were caused by rotten tubers, going up to more than $10 \%$ on 15 September. Losses due to water loss and respiration were going up to 5 - $6 \%$ on 15 September.

Figure 4.3 and Figure 4.4 show a very high variation between samples in storage efficiency, both in the upgraded and traditional chambers. Especially differences between samples in percentage of rotten tuber were very high. After a short storage period of three months (March to June) there were samples with $1.5 \%$ loss due to rot, but also samples with more than $20 \%$ rot. Quality of the potatoes was lower than in previous/other years, because of the bad harvest conditions in February/March 2015. Harvest was delayed due to rain fall and moment of loading the store was later than in other years. At the moment of preparing the samples an assessment of mechanical damage was done. It appeared that several tubers were showing skin damage (estimation: $10 \%$ of the tubers had $5-10 \%$ of skin removed).

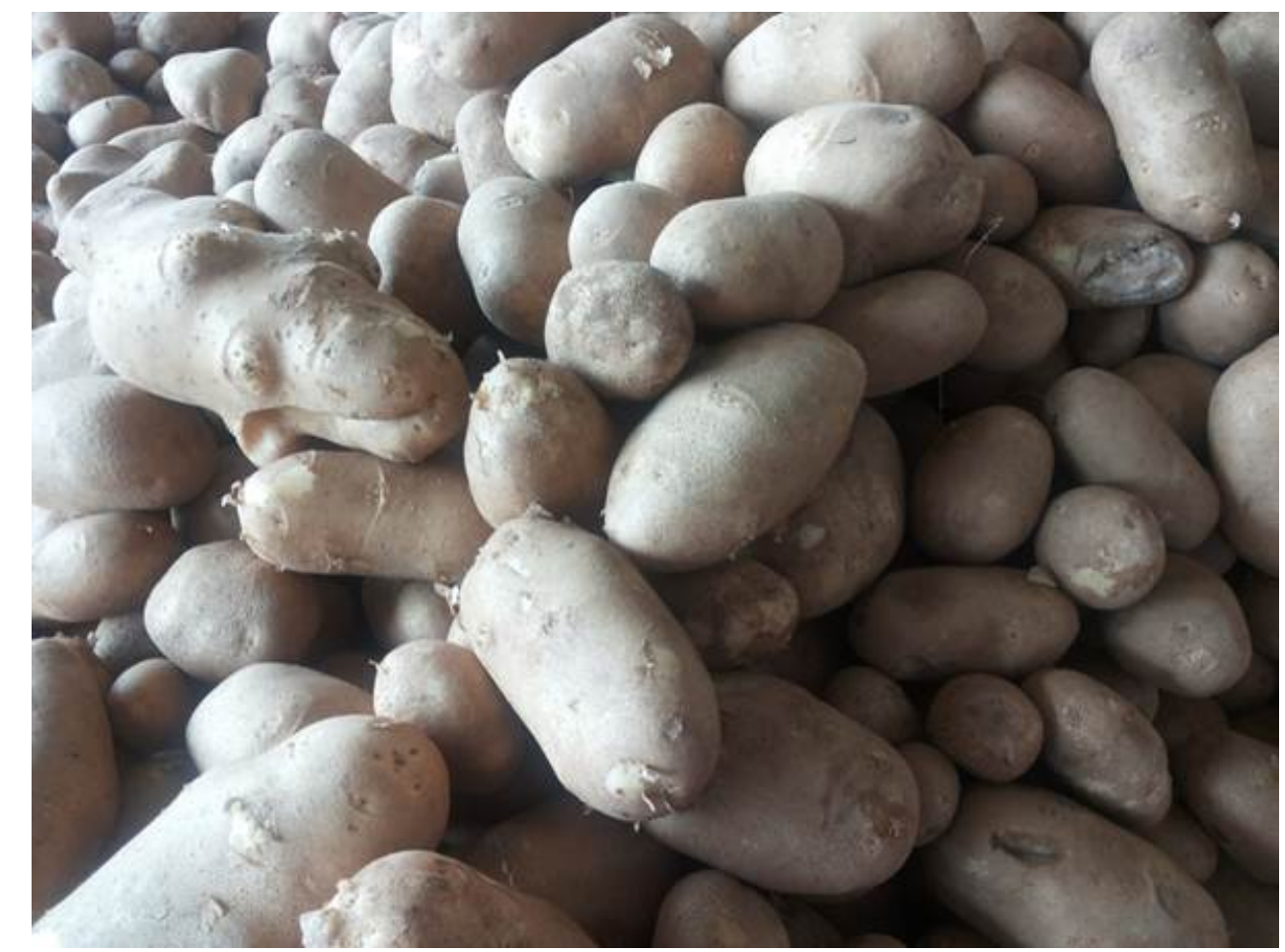

Figure 4.6 Potato lot before preparing samples.

Samples were prepared careful in a way that at the start of the storage period quality differences between samples were as small as possible. But, it is possible that quality differences between samples at the start of the storage period were still too large. If research will be continued sample size should be larger or more samples should be analysed at the different analysing moments. The results are not showing a reliable difference between upgraded and traditional chambers. The differences are small and the variation between samples within a chamber is very high. It is a pity that the traditional chambers were unloaded already in the beginning of August. Therefore it was not possible to measure the differences between upgraded and traditional chambers after 5 months.

If research will be continued in the next storage season more samples per moment of sampling should be analysed and storage period in traditional chambers should be longer. The largest differences could be expected after a storage period of 8 - 9 months.

As shown by Figure 4.3 and Figure 4.4, fluctuations in storage efficiency on different locations within chambers are very high. So, it is not possible to draw conclusions about differences between locations within a chamber in storage losses. This is true for traditional and upgraded chambers.

The experiment with six wireless temperature sensors on different locations in the stacks is showing that in the upgraded chamber temperature differences were much smaller than in the traditional chamber. Also temperature level was going down much faster in the upgraded chamber than in the 
traditional chamber. Another difference is that temperature level that was reached in the upgraded chamber was lower than in the traditional chamber. At the moment of preparing this report no information was available about the programmed cooling down schedule in both chambers. Also data of the air and temperature sensors were not available. However, the experiment is showing very clearly that in the upgraded chamber storage conditions within the stacks were more uniform than in the traditional chamber.

Quality of the potatoes is an important factor in obtaining good storage results. The experiment of 2015 has shown that loss of skins can be high. For 2016 it is proposed to include different levels of skin setting in the experiments.

\subsubsection{Conclusions}

The following conclusions were found for this year's experiments:

- Harvest was delayed due to rainfall and the moment of loading the store was later than in other years.

- The quality of the potatoes to be stored was lower than in previous/other years, because of the bad harvest conditions in February/March 2015.

- In the Real Cold Store in Himmatnagar, losses due to water loss and respiration were relatively high (about 5 to $6 \%$ ) by mid-September.

- In the Real Cold Store in Himmatnagar, the effects of long storage benefits ( 5 months) on potato processing quality of the upgraded storage system compared to the traditional storage system good not be made as the traditional system was unloaded at the beginning of August.

- In the Real Cold Store in Himmatnagar, losses due to rotten tubers were relatively high (about $10 \%)$ by mid-September.

- In the Real Cold Store in Himmatnagar, differences between the samples from different locations was high, indicating that storage conditions were not uniform.

- If research is to be continued potatoes have to put in storage earlier than in 2015.

- $\quad$ Skin curing should be included in the experiments as a factor to evaluate.

- If research is to be continued more samples per moment of sampling should be analysed.

\subsubsection{Storage experiment in the Shakti Fruits and Vegetables store, 2015}

\subsubsection{Introduction}

In 2015, a storage experiment was conducted in the Shakti Fruits and Vegetables bag store in Palanpur. The store was built in 2014. The storage equipment was installed by Omnivent. In one of the chambers of this store $10 \mathrm{~kg}$ samples were stored and as a reference $10 \mathrm{~kg}$ samples were stored in a traditional store in the neighbourhood, the Meghdoot store.

The aim of the experiments was:

- To compare the Shakti store with Omnivent equipment and a traditional store with respect to weight losses and quality of stored potatoes.

\subsubsection{Methods}

On 25 March 2015, 43 samples were taken from an uniform potato lot owned by Hyfun Foods. The variety was Santana. Each sample had a size of $\pm 10 \mathrm{~kg}$. Healthy potatoes were chosen and each sample was put in a netted bag. Exact weight of the samples was determined just before putting the samples in the store. The samples were labelled in a way that weights losses could be measured for each individual sample.

On all five floors samples were stored on 2 locations close to the Omnivent temperature sensors. On each location 4 samples were stored. Stacking height was seven bags. The $10 \mathrm{~kg}$ samples were stored on top of the stack, between bag layers six and seven.

On the same day, 25 March, 3 samples were stored in the Meghdoot traditional store. The three samples were stored in the same way as in the Shakti store in stacks on different floors. 
On 8 December, samples were removed from both stores. At the laboratory of Hyfun Food total weight of each sample was assessed. Each sample was split up in two parts:

1. Healthy tubers and healthy parts of tubers with less than $25 \%$ rot;

2. Rotten tubers (criteria: more than $25 \%$ rot) and rotten parts of tubers with less than $25 \%$ rot (residues are added to rotten tubers).

The weight of the healthy tubers and the weight of the rotten tubers was assessed. From each sample 20 tubers were taken for the assessment of frying quality. Frying quality was assessed according to the method of Hyfun Food.

\subsubsection{Results}

Table 4.6 presents for each location in the Shakti store losses due to loss of water and respiration, losses due to rot and storage efficiency (expressed as percentage of healthy potatoes after storage in relation to initial weight). Also frying quality data are presented in Table 4.6. Also the losses, storage efficiency and frying quality of the samples stored in the Meghdoot traditional store are presented in Table 4.6.

Table 4.6.

Water plus respiration losses (\%) and losses due to rot (\%), and storage efficiency and frying quality of samples stored at different locations in the Shakti Fruits and Vegetable store in Palanpur 2015. Mean values of 4 samples.

\begin{tabular}{|c|c|c|c|c|c|}
\hline \multirow[b]{2}{*}{$\begin{array}{l}\text { Shakti store } \\
\text { (Omnivent system) }\end{array}$} & \multirow[b]{2}{*}{$\begin{array}{l}\text { water plus } \\
\text { respiration }\end{array}$} & \multirow[b]{2}{*}{ rot } & \multirow[b]{2}{*}{$\begin{array}{l}\text { Storage } \\
\text { efficiency }{ }^{1}\end{array}$} & \multicolumn{2}{|l|}{ Frying quality } \\
\hline & & & & $\begin{array}{l}\% \text { of sticks in } \\
\text { class } 3 \& 4\end{array}$ & $\begin{array}{l}\% \text { of stick } \\
\text { "sugar end" }\end{array}$ \\
\hline $1^{\text {st }}$ floor loc $A^{2}$ & 10.5 & 3.2 & 86.7 & 16.3 & 34.9 \\
\hline $1^{\text {st }}$ floor loc B & 10.3 & 1.7 & 87.9 & 11.3 & 32.5 \\
\hline $2^{\text {nd }}$ floor loc $A$ & 9.8 & 3 & 87.1 & 20.0 & 26.3 \\
\hline $2^{\text {nd }}$ floor loc B & 9.9 & 2 & 88.0 & 23.8 & 33.8 \\
\hline $3^{\text {rd }}$ floor loc $A$ & 9.8 & 3 & 87.1 & 15.0 & 28.8 \\
\hline $3^{\text {rd }}$ floor loc $B$ & 10 & 2.2 & 88.0 & 17.5 & 25.0 \\
\hline $4^{\text {th }}$ floor loc $A$ & 10.3 & 3.1 & 87.0 & 22.5 & 42.5 \\
\hline $4^{\text {th }}$ floor loc B & 10.2 & 2.6 & 87.2 & 20.0 & 23.8 \\
\hline $5^{\text {th }}$ floor loc $A$ & 10.9 & 1.2 & 87.9 & 16.3 & 32.5 \\
\hline $5^{\text {th }}$ floor loc B & 10.5 & 1.6 & 87.6 & 12.6 & 37.9 \\
\hline \multicolumn{6}{|c|}{ Meghdoot store (traditional) } \\
\hline Mean of 3 samples $^{3}$ & 41.1 & 8.7 & 78.2 & 30.0 & 28.3 \\
\hline
\end{tabular}

$1 \%$ healthy potatoes relative to initial weight

2 on each location 4 samples

${ }^{3}$ large differences between samples (storage efficiency: sample 1: 68,3 ; sample 2: 82,5 and sample 3: 84,9 )

\subsubsection{Discussion}

In the Shakti store, losses due to water loss and respiration were relatively high (about 10\%), while losses due to rot were relatively low (going up to about 3\%). Between locations within the Shakti store there were no differences in storage losses. This means that storage conditions were uniform in the Shakti store. In the Meghdoot traditional store losses were much higher than in the Shakti store, especially losses due to rot were high in the Meghdoot store. However the number of samples in the Meghdoot store was low: only three samples. Moreover there were big differences between the three samples is this store: one sample was showing high losses, mainly due to rot, while the other two samples were performing better.

Generally the criteria for quality are: not more than $15 \%$ sticks in class 3 and 4 and not more than $10 \%$ "sugar end".

In the Shakti store, the average percentage of sticks in class 3 and 4 was lower than in the Meghdoot store. At 3 out of 10 locations in the Shakti store the quality criteria for sticks were met. The quality 
criterion for percentage of sugar end was not met in both stores. In general fry quality was low in this experiment. This is caused by the low quality of the potatoes at the start of the storage period and probably also by the long storage period.

Quality of the potatoes used in this experiment was much lower than normal. Compared to other years, harvest was delayed due to rain fall. The moment of putting the samples in the stores was about three weeks later than in previous and other years. This means that temperature outside the store ranged between 32 till $42^{\circ} \mathrm{C}$. These conditions have influenced the results of the experiment.

For 2016 the experiment should be repeated in a way that the moment of putting potatoes in the store should be earlier. Loss of skins is also an important factor. Therefore, it is proposed to include in 2016 different levels of skin setting in the experiments.

\subsubsection{Conclusions}

The following conclusions were found for this year's experiments:

- Harvest was delayed due to rainfall and the moment of loading the store was later than in other years.

- The quality of the potatoes to be stored was lower than in previous/other years, because of the bad harvest conditions in February/March 2015.

- Losses due to water loss and respiration were relatively high (about 10\%)

- Differences between the samples from different locations were small, indicating that the storage conditions were uniform.

- The potato quality criteria for sticks were met 3 out of 10 locations which was better than for the traditional storage.

- If research is to be continued potatoes have to put in storage earlier than in 2015.

- $\quad$ Skin curing should be included in the experiments as a factor to evaluate.

- If research is to be continued more samples per moment of sampling should be analysed.

\subsection{Experiments on cold storage, 2016}

Frank ter Beke Wageningen University \& Research, Wageningen, The Netherlands

Praneet Pathak, NAFTC India

Bhavinumar Thank, McCain, India.

Objective

The objective of the trial is to make head to head comparisons of advanced/upgraded cold storages with a traditional one. Also to observe the difference in losses due to handling- farmer's practice vs instructed handling.

There were two types of samples taken for the trial and the handling was also different in both the samples:

- In the $1^{\text {st }}$ practices traditional type of harvesting was practiced, where irrigation was stopped after 95 DAP for the natural death of the haulm and now onward we will call it $\mathrm{H} 1$.

- In the 2 nd practices we ensured haulm cutting at the time of crop maturity (95 DAP) and now onward we will call it $\mathrm{H} 2$.

Process of haulm killing

The vegetative part of the plant was cut off with the help of a sickle. It was cleared from the base near the soil level.

Crop would be kept till natural drying and skin set for 15 days from the crop maturity. Following are the few important data $\&$ dates in reference to the crop:

- Variety: Innovator

- Date of Planting: 23/11/2015

- Date of last irrigation: 26/02/2016

- Date of haulm destruction (for $\mathrm{H} 1$ ): 26/06/2016 
- $\quad$ Date of last drip with little water for loosening the soil: 9/03/2016

- Date of Harvesting: 12/03/2016

The Field

The samples for $\mathrm{H} 2$ were collected from two and a half rows in the field each with a length of 110 meter. The width of the bed was 1.34 meter. In these three rows the haulm was destroyed as mentioned above. The rest produce from the same field was marked for $\mathrm{H} 1$. The outside temperature during the time of harvesting was around 32 degree C. Tuber temperature at harvest 26 degree C. Harvesting, handling and sampling

A tractor attached digger was used for the harvesting which was moving at an approximate speed of 2 $\mathrm{km} / \mathrm{hr}$. I $\mathrm{n} \mathrm{l}$ rows the potatoes were gathered from the field by workers in small plastic baskets and were then transferred to a trolley. The filled trolley was then moved to the farmer's place where workers were grading the produce. The handling in the complete process was very rough. Workers after picking the potatoes from the field were throwing them on the baskets and later these baskets were emptied in the trolley from a height of almost 1 meter. This way there was a lot of damage in the tubers. The hydraulic trolley unloaded the potatoes on the floor. From here we collected 149 (tagged 1 to 149 ) samples of $\mathrm{H} 1$ with an estimated weight of $10 \mathrm{~kg}$ per sample. For weight estimation first a bag was filled and weighted $(10 \mathrm{~kg})$. Latter all sample bags were more or less filled till the same level.

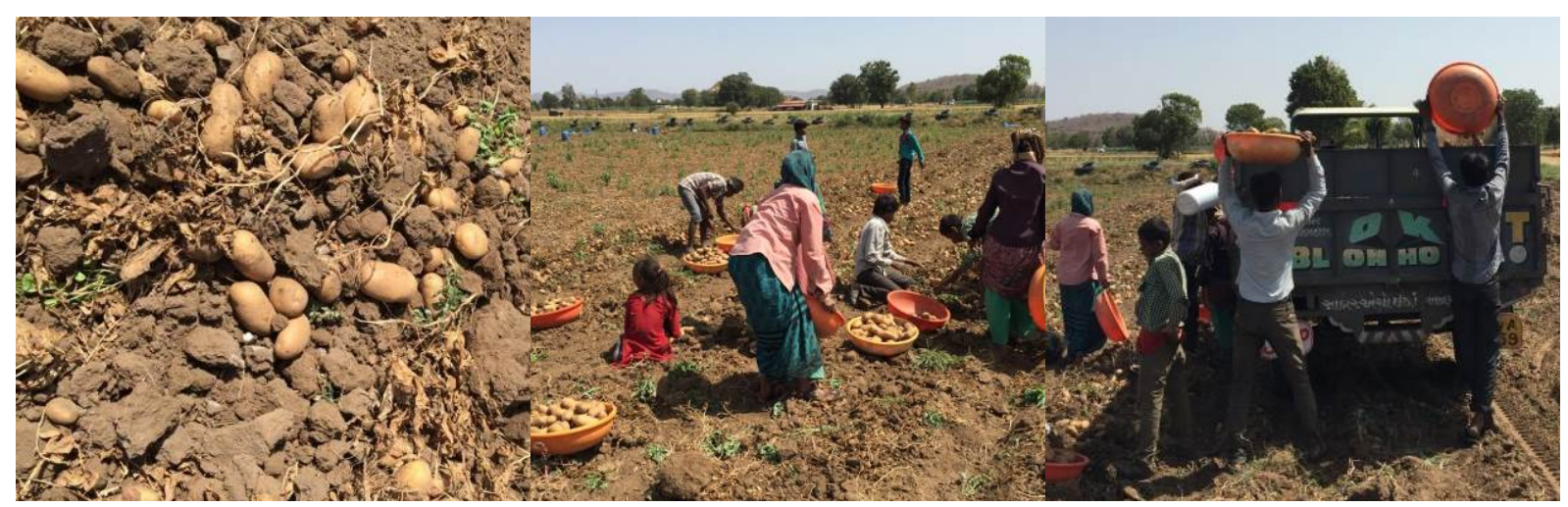

Figure 4.7 Harvesting potatoes and leading the truck for transport

For collecting $\mathrm{H} 2$ samples the handling was minimized. There was no transportation of the produce to the trolley $\&$ to the farmer's place. The $10 \mathrm{~kg}$ bags were directly filled from the field and we graded $\&$ collected 137 (tagged 1001 to 1137) samples for H2 (as there were limited rows for $\mathrm{H} 2$ ). The weight estimation was done similar to the $\mathrm{H} 1$.

The harvesting process started at around 12 noon and took some two hours. The sampling of both $\mathrm{H} 1$ $\& \mathrm{H} 2$ was finished by 19:00 hrs including the tagging of the sample bags. Sample for McCain bruise test were also collected for $\mathrm{H} 1 \& \mathrm{H} 2$. The tags with a unique number were attached to the each sample. One tag was kept inside the bag and bag was tied with a rope. Another tag with the same number as inside was tied on the outside of the sample bag. This process was repeated for all the samples- $\mathrm{H} 1 \& \mathrm{H} 2$. The $\mathrm{H} 1$ samples were in WHITE \& ORANGE bags and H2 in YELLOW bags.

\section{Transport and weighting}

The next day these samples (both $\mathrm{H} 1 \& \mathrm{H} 2$ ) were transported to the cold storage (Real cold storeMooij technology) and were kept in the shade $\&$ all samples were weighted the same day in a single weighing machine to minimize the error of machines. The weight data of the samples is mentioned in the attached excel sheet.

\section{The placement}

The placement of the samples was done in a similar fashion in all the cold storages. We placed the samples for study in the following cold storages:

1. Real Cold Store, Waktapur (9 km from Himmatnagar): Mooij Technology (Chamber 3) 
2. Ramdev Cold Store, Ranasan (25 km from Himmatnagar): Omnivent Technology (Chamber 1)

3. Anmol Cold Store, Daramli (19 km from Himmatnagar): Traditional Technology (Chamber C)

4. Adithya Cold Store, Daramli (19 km from Himmatnagar): Tolsma Technology (Chamber 3)

The placement started a day after weighing the samples. Firstly the samples were placed in the Mooij Storage on 14th March 2016. On 15 th March 2016 the samples were placed in the Traditional \& Tolsma storages. And for Omnivent technology the placement of the samples was done on 16 $6^{\text {th }}$ March 2016. Data loggers were placed along the samples in all stores. Samples were placed near the temperature sensors. The operators were instructed not to change the position of the sensors.

In all stores the placement of the samples was done in level $1,3 \& 5$ in a single chamber. At every level samples were placed in two locations near the temperature sensors. At every location the tag numbers of the sample bags were noted in a paper. In ever location we placed $6 \mathrm{H} 1 \& 6 \mathrm{H} 2$ samples. Random samples were placed at both the locations in a floor. It was made sure that the samples are not placed in the outer part of the stack. From a stack, bags from layer 8 and layer 7 were removed and 12 samples bags ( $6 \mathrm{H} 1 \& 6 \mathrm{H} 2$ ) were placed as the 7 th layer and then it was covered with $50 \mathrm{~kg}$ bags as 8th layer. For placing the 12 sample bags at every location 8 bags from 4 rows were removed ( 2 layers from ever row). During the complete process it was made sure that there is no hard handling of the samples to minimize the damage. After covering the samples the layer 8 bags were tagged with a plastic rope so that they can be traced easily later. There was a difference in the placement for Omnivent due to limited number of $\mathrm{H} 2$ samples. At Omnivent store $9 \mathrm{H} 2$ samples were placed in each floor. $6 \mathrm{H} 1 \& 6 \mathrm{H} 2$ towards the outer side of the chamber and $6 \mathrm{H} 1 \& 3 \mathrm{H} 2$ towards the inner side of the chamber. Also a location tag was hanged from the roof near the samples to locate the place. The pillar nos. / frame nos. was also noted in the paper along with the sensor no. at that location. Also a floor plan was drawn in the paper where location of the samples was marked with approximate distance from the walls/gallery.

\section{Comparison of storability in modified vs Traditional storages}

\section{Table 4.7.}

Overview objectives and samples in all stores

\begin{tabular}{|c|c|c|c|c|c|c|c|c|c|}
\hline \multirow[b]{3}{*}{ Sample } & \multirow[b]{3}{*}{ Harvest } & \multirow{3}{*}{$\begin{array}{l}\text { Sample } \\
\text { size }\end{array}$} & \multicolumn{2}{|l|}{ Total } & \multicolumn{5}{|l|}{ Total } \\
\hline & & & Samples & Floors & samples & Traditional & Tolsma & Mooij & Omnivent \\
\hline & & & per floor & per CS & per CS & Storage & Storage & Storage & Storage \\
\hline $\mathrm{H} 1$ & Traditional & $10 \mathrm{~kg}$ & 12 & $\begin{array}{l}\text { 1st, 3rd } \\
\& 5 \text { th }\end{array}$ & 36 & $\begin{array}{l}360 \mathrm{~kg}-36 \\
\text { Samples }\end{array}$ & $\begin{array}{l}360 \mathrm{~kg}-36 \\
\text { Samples }\end{array}$ & $\begin{array}{l}360 \mathrm{~kg}-36 \\
\text { Samples }\end{array}$ & $\begin{array}{l}360 \mathrm{~kg}-36 \\
\text { Samples }\end{array}$ \\
\hline $\mathrm{H} 2$ & $\begin{array}{l}\text { Haulm } \\
\text { cutting }\end{array}$ & $10 \mathrm{~kg}$ & 12 & $\begin{array}{l}\text { 1st, 3rd } \\
\& 5 \text { th }\end{array}$ & 36 & $\begin{array}{l}360 \mathrm{~kg}-36 \\
\text { Samples }\end{array}$ & $\begin{array}{l}360 \mathrm{~kg}-36 \\
\text { Samples }\end{array}$ & $\begin{array}{l}360 \mathrm{~kg}-36 \\
\text { Samples }\end{array}$ & $\begin{array}{l}270 \mathrm{~kg}-27 \\
\text { Samples }\end{array}$ \\
\hline
\end{tabular}

The location tags were numbered as $11 \& 12$ for level $1,31 \& 32$ for level 3 and $51 \& 52$ for level 5 . Apart from this technology of the store was also marked in the tags. Example: for locations in the $5^{\text {th }}$ level at Mooij store the location tags were MOOIJ $51 \&$ MOOIJ 52. Similarly for level 3 at Omnivent store the tags were OMNI $31 \&$ OMNI 32.

\section{Data loggers}

Data loggers were also placed in all the stores. A proper stack was selected in all the stores and 6 data loggers per store were placed. In a the Real Cold Store (Mooij) were placed during the stacking was going on $\&$ it was done in $3^{\text {rd }}$ floor. But as loading process was already complete in the Adithya (Tolsma) and Anmol Cold Stores stack of 8 bags 3 data loggers were placed above the $3^{\text {rd }}$ layer and other 3 over the $6^{\text {th }}$ layer. At Omnivent store apart from these, two other data logger were placed in the outer layer of the stack above layer $3 \& 6$. Data loggers at (Traditional) so it was not quite possible to place the data loggers at level 3 so for Adithya Cold Store (Tolsma) \& Anmol Cold Store (Traditional) the data loggers were placed in $4^{\text {th }}$ floor. At Ramdev Cold Store (Omnivent) data loggers were again placed in $3^{\text {rd }}$ floor. 


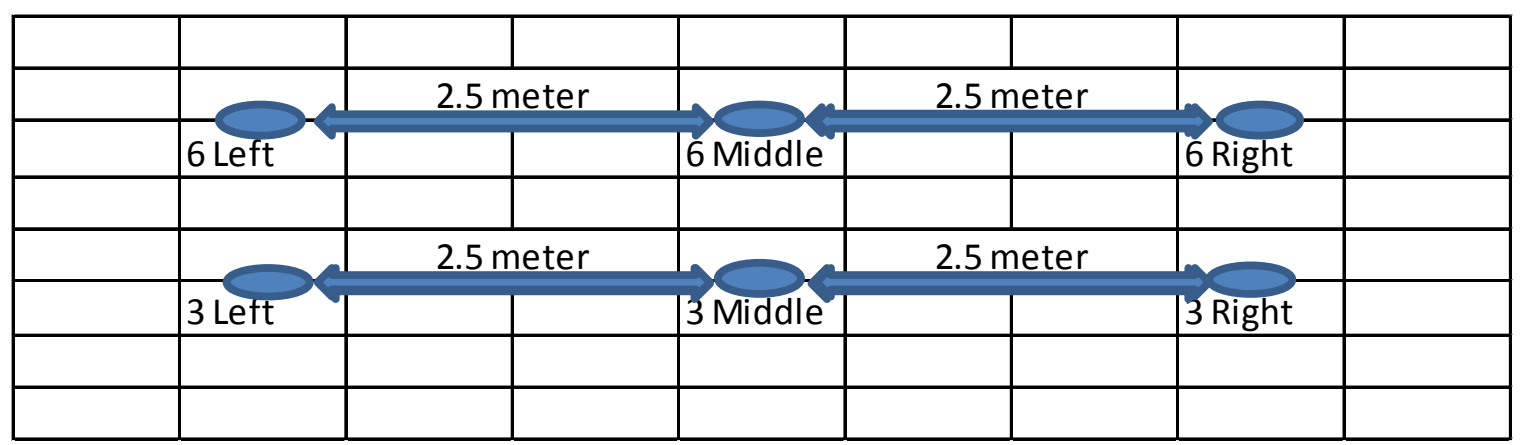

Figure 4.8 Sample placement data logger at the stack

Progress and the final conclusions will be published in a separate document as an appendix of this report. 


\section{$5 \quad$ Seed potatoes}

Anton Haverkort, Wageningen University \& Research, Wageningen, The Netherlands

\subsection{Introduction}

India currently grows potato on approximately 2 million hectares with a yield of 23 t/ha resulting in an annual production of 46 million tons. At INR 10 per $\mathrm{kg}$ farm gate price this represents a value of INR 460 billion (USD 6.57 billion). Consumer and seed users value is almost double, say USD 10 billion. The amount of seed used is 3.2 million tons per year much of it is imported annually from Punjab as in many areas farmers do not save their own seed. In some areas, however, such as Andhra Pradesh, farmers may multiply the seed once or twice before refreshing. This makes the Indian seed potato industry probably the largest in the world. China grows more potatoes but the proportion of farm saved seed there is much larger than in India. Compared to other major potato industries such as those of Northern Europe and North America two features differ:

- With a few exceptions for processing purposes (e.g. Lady Rosetta for crisps and Innovator for chips) all varieties grown in India are bred in India by CPRI at Shimla whereas in Europe and America a wide range of national and international varieties are grown, both for processing and for the fresh market.

- In the bulk of the India seed produced and planted is not officially certified whereas in Europe and America all seed potatoes are certified mandatory based on a declass system and after about 6-7 field generations are destined for the processing and ware potato market.

As a consequence growers in aforementioned foreign markets have available to them healthy seed tubers of a wide array of varieties for many fresh and processing markets, including the export of seed potatoes, among other to neighbouring countries of India, Pakistan and Bangladesh. This note is intended to develop thoughts on making the Indian potato industry more competitive vis-a-vis other foodstuffs in India and vis-a-vis other exporting markets thereby possibly opening nearby markets in the region. Having a growing season of seed potatoes in India from October to January already gives India a competitive advantage over seed exporting countries from the northern Hemisphere as at the next autumn planting of Indian seed potatoes it is not dormant whereas that from the North is. Yield gap analyses have shown that improvement of propagation material, nutrition, crop protection and water supply at marginal costs - input of knowledge mainly and organizational aspects - may lead to a $50 \%$ yield increase conservatively valued at USD 3 billion per annum.

\subsection{Steps to be made}

Attention was given to and subject of intended meetings by the COPE (Chapter 7) are:

1. Commercial Registration of foreign varieties (aspects: procedures, protocols, transparency, independency,...) aimed at rapidly increasing the genetic base of potato in India allowing farmers more degrees of freedom

2. Official massive certification of seed potatoes (same aspects as for registration) aimed at improving and guaranteeing seed health

All stakeholders such as seed growers associated with Mahindra-HZPC and POSCON, governmental bodies such as CPRI, Punjab Agricultural University (and possibly those involved in the Centre of Potato Expertise - COPE) and government officials at Chandighar from the State Horticultural Mission will benefit. CPRI by charging fees for registration and certification thereby increasing its turnover; 
seed growers have available more healthy seed leading to higher yields and lower costs; traders open up international regional markets; consumers and processors have available a wider range of varieties fitting more tastes, more environments, more processing qualities, more resistances to pests and diseases and less susceptible to degeneration over generations. Beside attention to these institutional matters seed improvement trials through various defoliation treatments were carried out (ongoing on January 1) with POSCON and training of Mahindra-HZPC was planned for 2015 but postponed to 2016 on the following subjects: variety profiling and registration, seed certification model, economics, potato diseases and control, yield gap analysis, decision support systems, m-Astra, foot printing, resource use efficiency and product diversity in supermarkets. 


\section{Impressions of IlanBio's micro- tubers: production, use and $R \& D$ aimed at exploitation}

Anton Haverkort, Wageningen University \& Research, Wageningen, The Netherlands

\subsection{Introduction}

Within the framework of the Netherlands Topsector Public Private Partnership India-Ethiopia funded by the Netherlands Ministry of Economic affairs (MinEZ) and managed by the Netherlands Agro Food Technology Center (NAFTC) two visits were paid to Ilan Bio (http://ilanbio.com/about/profile/) in Tel Aviv. In 2014 the laboratory was visited with Jan Hak of NAFTC and Tom van der Kooij of HZPC at Tel Aviv and planting was observed at the Golan Height. Suggestions for comparison of micro-tuber and mini-tuber field performance in the Netherlands and in Israel were given. In April 2015 a second visit was paid to IlanBio and a field trial in the Negev was visited in attendance of Mr Sujit Bhatti and dr. Gang of Bhatti farms in J alandhar, Punjab, India. Performance was observed and avenues for cooperation explored. This short note gives a brief impression of the company/micro-tubers, of the field performance and some options for exploitation $R \& D$ opportunities for future use in e.g. India. IlanBio (from web site and own observations interpretations).

IlanBio, an agro-biotechnology company is in the forefront of large-scale in vitro plant propagation cloning, technologies. The company developed a highly efficient system for the establishment, multiplication and acclimatization of uniform, disease-free elite tissue culture plants and an innovative biologically controlled micro propagation system in liquid bioreactor cultures. IlanBio maintains a world-wide advanced biotechnology laboratory, which is based on a novel liquid system in bioreactor cultures. The innovative developments of the in vitro system in IlanBio; provides an economic agricultural plant propagation system; has a significant potential for plant bioactive compounds production; a dependable company for cooperation with research and development institutes. The production, research and development protocols for all the plant species, is carried out by an academic, experienced and reliable research group.

The bioreactor system owned by IlanBio is a temporary immersion system (TIS), one of the most advanced globally, that allows carbon dioxide enrichment and a photoautotrophic production process. IlanBio's technology is an IP (intellectual property) trade secret. The company does not publish specific information. However, the system has the following advantages:

- A high multiplication factor (number of tubers per in-vitro plantlet per unit of time),

- Uniform material compared to that from hydroponics and aeroponics,

- $\quad$ Reduction in the risk of contamination during the process.

- $\quad$ No exposure to outside environment during growth of the tubers in vitro

- $\quad$ Year round production independent of outside weather, so ready when needed

- $\quad$ A reduction in manpower during the propagation and growth process.

- $\quad$ Low production costs relative to traditional tissue culture laboratories

- $\quad$ Potential to automate the process in future.

IlanBio produces micro and mini tubers in generation 0 and 1, and has over 115 different potato varieties, all pathogen-free. Among them are the leading industry varieties: Desiree, Lady Rosetta, Shepody, Atlantic, Nicola and Vivaldi.

Propagation by this company is through undisclosed procedures (black box) but disclosed is that it takes place in about $25 \mathrm{~L}$ containers under fluorescent light (TL-tubes). In-Vitro plants enter this 
container, are grown intermittently submerged in liquid media. When plants are large enough sugar is added, plants are placed in the dark and then they translocate biomass from foliage to tubers. IlanBio claims more rapid, higher numbers at lower costs technique than found on market however seem to confuse their micro with other company's mini-tubers. Resulting micro-tubers are classified into small $(<1 . \mathrm{g})$, medium $(>1 \mathrm{~g},<2.5 \mathrm{~g}$ ) and large $(>2.5 \mathrm{~g})$. The next generation can be planted immediately leaving incubator (continuing their (secondary) growth or after hardening when still attached to mother plant and 4 month cold store. The observed lenticells callus formation may be an issue as it may make the tuberlets vulnerable. A scientific proper comparison would seem to be invitro plantlets (from sterile conditions) yielding minis in the next generation to micro-tubers (from sterile conditions) yielding minis. Scheme of production below:

\section{Container producing in- vitro plantlets}

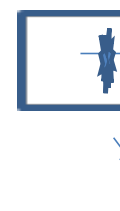

\section{Bioreactor Temporary Immersion System Producing micro-tubers Ilan Bio}

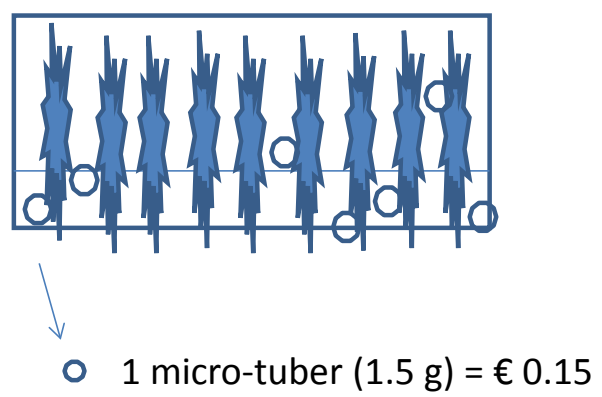

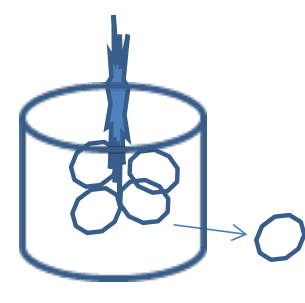

1 mini-tuber $(30 \mathrm{~g})=€ 0.45$

- 1 micro-tuber $(1.5 \mathrm{~g})=€ 0.15$

Figure 6.1 Comparison between the production of mini-tubers on plantlets in pot from in-vitro plantlets and from plants from micro-tubers.

Observations at field visit. Ramat Negev Mountain Research Station April 30, 2015, IlanBio personnel with 2 persons of Bhatti Farms. Note lay out of field visited was a demonstration, not a randomized field trial. Treatments:

- Nicola and Désirée ads varieties tested

- Mini-tubers, micro-tubers, seed tubers as forms of propagation material (seed and minis imported from Scotland)

- Three planting dates. crops were 90, 50 and 22 days old on Aril 302015

- Micro-tubers were planted at 4, 8 and 12 plant per meter (rows $90 \mathrm{~cm}$ apart)

Only qualitative observations were made and the following seen:

- Crop stand (foliage size) was largest of imported seed tubers, then of mini-tubers than of micro-tubers. The picture below shows the Nicola crop from IlanBio micro tubers 28 days after planting and from imported seed tubers 33 days after planting. Large seed tubers clearly have a much earlier crop establishment; hence higher yields at 90 days after planting.

- Crops from mini-tubers and seed tubers after 90 days had too high a proportion of large tubers; with a higher value of small sized tubers than large ones these crops should have been harvested well before.

- Yield of Nicola from one micro-tuber was about equal to the yield of Désirée from 3 microtubers; see second picture on page 3.

- Yields from micro-tubers at 90 days after planting were quite impressive though lower than from normal seed tubers but more tubers in seed sized grade. Matter of calculus. 
- Yield - number and weight - depend on source of propagation material both variety and material

- Note Nicola to be planted wide spaced, micros make 12 tubers seed size after 90 days. Désirée only 13 should be planted more narrow.

- Observation: imported seed tubers showed symptoms of viruses and black leg. Insects including aphids - abound

- This shows that the idea of bringing clean seed to new areas should be only from in vitro (micro, mini) as contamination by seed that was grown in a field abroad has hazards

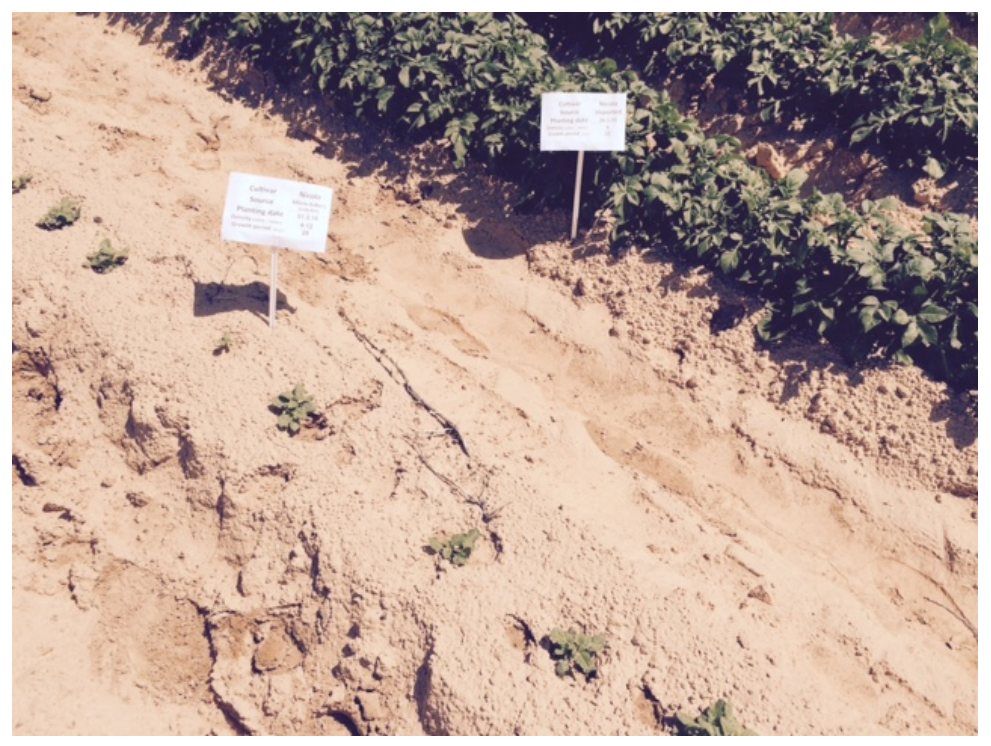

Figure 6.2 Nicola crop left: from IlanBio micro tubers 28 days after planting, right from imported seed tubers 33 days after planting.
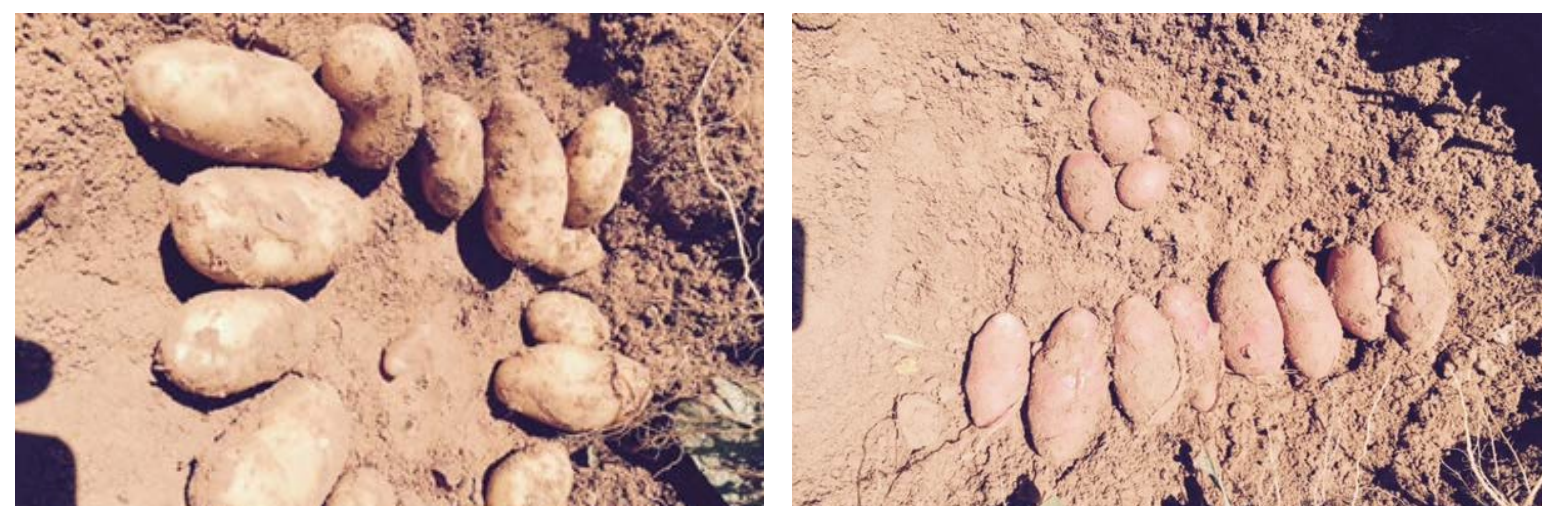

Figure 6.3 Yield of Nicola from one micro-tuber (mother in the centre, left); Yield of Désirée from 3 micro-tubers (right). Both 90 days after planting.

\subsection{Steps forward from a research perspective}

- Carry out field research experiments with statistically viable protocols (randomized multireplicated trials). Treatments as those found in the current 2015 season at Ramat Negev Mountain Research Station seem satisfactorily albeit variety choice needs attention. The demonstration plots in the Negev in 2015 give good impressions but no scientific evidence.

- Re business model a two-way development: seems adequate: IlanBio makes micros from Khandramukhi and Kufri's from India and Bhatti Farm tests it for its value from there. The thus generated knowledge benefits both partners when results are known (how do the Indian genotypes perform in vitro and in the field compared to 'peer' varieties?).

- $\quad$ Take further R\&D (and Business models based upon science) from there. 


\section{Centres of Excellence (CoE) in Punjab (Jalandhar) and Uttar Pradesh, and the Centre of Potato Expertise (COPE) at Ludhiana (Punjab)}

Anton Haverkort, Wageningen University \& Research, Wageningen, The Netherlands

\subsection{The Centre of Excellence}

The Centre of Excellence ( $\mathrm{COE}$ ) at Jalandhar has been established with Federal funding and expertise input from the Netherlands (PUM). To date no tender has been made public for stores and machinery. The CoE was visited by the Wageningen team in January 2015 and work plans were discussed. It is foreseen that the CoE will work closely together with the intended Centre of Potato Expertise (COPE) based at the Punjab Agricultural University. Meanwhile in 2015 the Chandra Shekhar Azad University of Agriculture and Technology at Kanpur in Uttar Pradesh also composed a Centre of Excellence for potato which was initially submitted to the State Government but subsequently submitted to the federal government. Involvement of NAFTC and Wageningen UR is foreseen. When the federal trajectory is followed, PUM's involvement is also called for. Currently this activity is monitored by the Agricultural Councillor Mr Wouter Verhey and NAFTC India director Prakesh Ramsing.
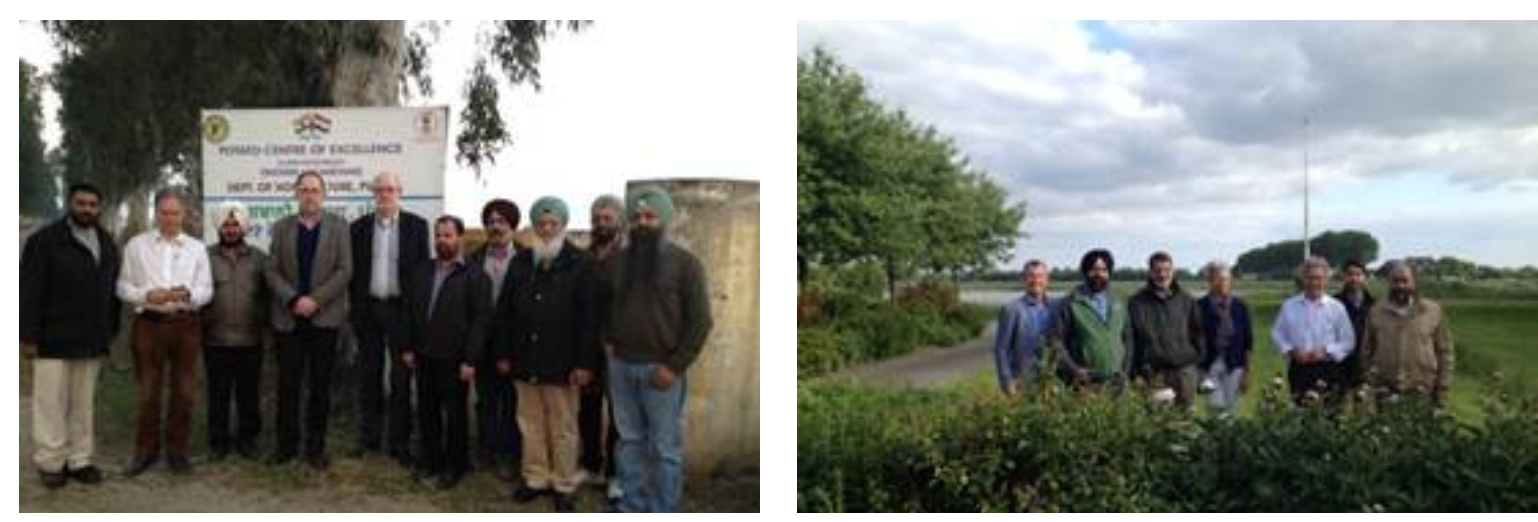

Figure 7.1 Visit to Centre of Excellence at Jalandhar (January 2015, left) and visit of some POSCON members to Wageningen ( $J$ une 2015, right).

\subsection{The Centre of Potato Expertise}

The State of Punjab has committed itself to the funding of a Centre of Potato Expertise (COPE) to be established at the premises of the Punjab Agricultural University (PAU) within the framework of the PAU-WUR MoU (backed by respectively POSCON and NAFTC). During the January 2015 visit meetings were held at the Department of Finance and Horticulture to discuss the organization of the COPE (steering and managerial, establishment of an independent "Society" that will receive the funds and generate tem through potato export (from Punjab) levies) and with PAU scientists at Ludhiana on January 30. Its budget is three million Euros. At the meetings a document "Proposal for the establishment of a "Centre of Potato Expertise" in Punjab was discussed and (re)written. 
At the scientific meeting at PAU in Ludhiana it was concluded that it is necessary to organize a twoday inception workshop on June $9+102015$ at PAU in Ludhiana. Later this meeting was postponed because funding was not forthcoming. Note the CoE is Dept. of Horticulture Extension "tool"; the COPE is a PAU R\&D 'tool".

Topics for the COPE R\&D program are:

- Variety evaluation and benchmarking.

- Yield gap analysis and resource use efficiency.

- $\quad$ Effects of climate change effects.

- Disease diagnostics and disease management (Decision Support System, especially for late blight control).

- Economics of production technology and machinery.

- Marketing strategies.

- Production technology, NPK, water management (establishment of Decision Support Systems).

- Seed certification (methodology and economics).

- Brochure showing results for extension purpose.

Participants (numbers tentative) should be from: Horticultural department Punjab State (2), POSCON (3), PAU (10), WUR (4), NAFTC (2) and CPRI (1). The result of the workshop should be a work plan / activities chart for the next two years starting with potato cropping season 2015-2016. Such a meeting is scheduled every year to report the past and to establish the annual plan for the next year. The subject will be raised again by all whom it concerns in 2016 . 


\section{Activities in Ethiopia}

Anton Haverkort, Wageningen University \& Research, Wageningen, The Netherlands

\subsection{Introduction}

In 2015 two main activities took place:

1. support to the Potato Platform based at the Addis Ababa Chamber of Commerce (ABSF) and

2. support to the FDOV project of Veris Investment to start a potato processing company in Ethiopia.

\subsection{Support to the Potato Platform based at the Addis Ababa Chamber of Commerce (ABSF)}

Through a one day workshop Business Opportunities for potato in Ethiopia deliverers were identified for inputs, for seed and for processing.

\subsubsection{Deliverers of crop inputs (substances and services)}

MACRO: Increasing population, more interest to consume (processed) food and potatoes etc. options to develop the chain. Earlier in this report the relatively lower pressure on resources land and water in Ethiopia than in some other East African countries so far reduces the need for Ethiopia to improve the use efficiency of the main resources land and water. With increasing population, urbanization and food from animal products also in Ethiopia improved use of land and water - with the rapid increase of irrigation schemes in the country - become important and will potato with its high land and water use efficiency play an increasingly important role. This - coupled to the versatile use of the crop (boiled, fried, mash) and the increasing role of its products in diets is the largest business opportunity for potato. Businesses supporting the higher area of the crop larger individual farms and fields with upscaling following urbanization and higher yields are the first ones to benefit: 1) producers and distributors of equipment and machinery, 2) agro-chemicals such as synthetic fertilizers and crop protection agents 3 ) along with service providers advising growers on the optimal use of such inputs. Examples of such companies exist in Ethiopia so this likely is a matter of more companies entering the market and others expanding.

\subsubsection{Producers of seed potatoes}

So far the bulk of the seed potatoes planted in Ethiopia consist of the sprouted left over, small tubers of the previous crop. Diseased plants yield smaller tubers than healthy plants so the use of small tubers enhances degeneration of seed.

For inputs to assure a higher rate of return, three of them need to be applied simultaneously:

1. healthy (certified) seed of appropriate varieties, this is more expensive by far than farm saved seed so needs to yield more and therefore has to be provided with more fertilizers and be protected better from pests and diseases to assure the rate of return,

2. fertilizers are needed to boost growth of plants emerging from this improved seed and 
3. crops need more/ better pesticides - especially fungicides - to protect the crop from late blight caused by Phytophthora infestans.

So businesses breeding and or selecting improved varieties (i.e. varieties that are better adapted to local growing conditions and more resistant to local pests and diseases) with higher yields and less in need of pesticides and producing healthy seed of these varieties through in-vitro and mini-tuber production and rapid multiplication, basic and certified seed multiplication will offer scope of profitably through their important basic role in the potato value chain. Part of business plans will be the remuneration of the efforts to breed new varieties such as through breeding rights also the organization of out-growers under contract multiplying seed for such companies and reselling after harvest. There likely is need for credit for many growers to purchase seed to cover the period between seed purchase - planting - harvest - and sale of produce. Possibilities of exporting propagation material to surrounding countries, including those in the Middle east certainly need to be explored. The company Solagrow is an example of a start-up of such a company within Ethiopia.

\subsubsection{Potato processors}

With an increasing role of potato as food stuff, increasing urban population with higher income and less time to buy ex-field food on the market and to prepare meals at home the global trend of the need for processed (potato) food will also be made felt in Ethiopia soon. The following products will enter the market to greater and great degree:

- $\quad$ Graded, sorted, washed, packed and branded fresh potatoes

- $\quad$ Crisps ( packed in various sizes and seasoned to like)

- $\quad$ Chips (French fries) frozen (storable for months) or chilled (storable for days)

- $\quad$ Potato flour (producing mashed potato when water or milk is added).

Potato processors need chains, need key businesses procuring the raw material at affordable prices year round mobilizing many small holders, need the processing equipment (grading, washing, (peeling cutting, blanching, frying, freezing) packing, and a sales and distribution apparatus. At small scale cottage type of such enterprises currently exists.

Secondly the terms of reference for a bench marking study recovery of potato products from potato raw material in Ethiopia were established: 


\section{Introduction}

Ethiopia produces well over 2 million tons of potato, the bulk of which is eaten boiled at home by the producer and her or his family and by consumers in cities buying from the markets or shops. From potato several products can be made in Ethiopia by processors that produce one or more of the following products:

- $\quad$ Branded graded, sorted, washed and packed potato for supermarkets,

- $\quad$ Frozen or chilled France fries (also called chips) sold in supermarkets,

- $\quad$ Crisps packed in plastic or aluminium foil wrapping seasoned with salt (and spices),

- $\quad$ Potato flour in small carton boxes (when reconstituted with water become mashed potato).

Currently potato processing in Ethiopia is almost non-existing, beside some very limited cottage industry crisps industry and packing for some supermarket. Road side sales of French fries and other fried potato is not an example of processing industry but rather of the food industry. Recently there is more interest in adding value to potato by processing them into products. The rate of recovery (the number of $\mathrm{kg}$ of finished product (PERFORMANCE) can be produced from $100 \mathrm{~kg}$ 'raw material'? Raw potato being the potato tubers as they appear when harvested from the soil. This performance is determined by the GENOTYPE (variety used), by the ENVIRONMENT and by the growers' MANAGEMENT practices:

Performance $=$ Genotype $\mathrm{x} \quad$ Environment $\mathrm{x}$ Management

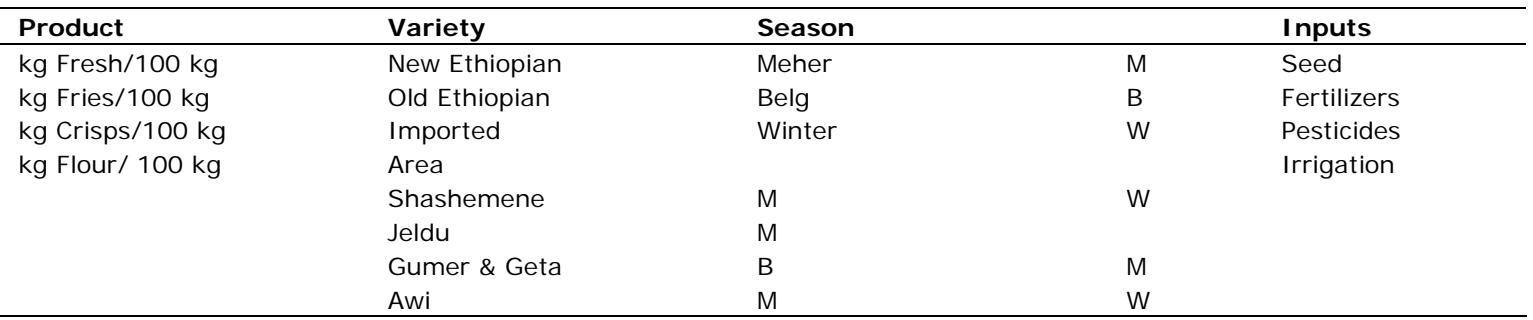

The objectives of this R\&D project are to make a survey of the actual performance of the possible products made from potato in Ethiopia for ulterior use. The performance is expressed as percentage recovery:

Recovery $=$ kg Finished Product per 100 kg Raw Material

The Performance Indicator is key information to any business wanting to process potato in Ethiopia as it indicates the major factor influencing the expected rate of return from purchased potato,

Approach

The recovery rate (Performance) of four products will be assessed:

1) Fresh, 2) Fries, 3) Crisps and 4) Flour.

The assessment (Performance) consists of the following aspects:

- Determination of the specifications. For each product: what are the specifications the raw material needs to meet in Ethiopian conditions. Examples are tuber size ( $\max$ and $\min$ ), flesh colour, length/width ratio, percentage defects (definition of defects), dry matter concentration, fry colour

- Assessment of each of the specifications and the resulting percentage of the crop that meets the specs

- $\quad$ Calculation of recovery as not each spec equally quantitatively determines the recovery rate. E.g. 
percentage dry matter influences percentage recovery 2.5 times more than percentage rejects.

The following varieties will be tested:

- $\quad$ The 'old traditional' Ethiopian varieties (local one)

- Three newly introduced varieties by EIAR (through CIP) such as Gudene, Jalene, Belete

- $\quad$ Five imported varieties and distributed by companies importing seed potatoes (e.g Solagrow). This in the winter season only as they are mainly grown then

The following environments (region $\mathrm{x}$ season stored) will be used to take raw material from:

- $\quad$ Four regions Shashemene (M, W), Jeldu (M), Gumer \& Geta (B, M), Awi (, , W) $(=7$ environments $x$ 4 varieties $=28$ treatments)

- $\quad$ Stored for 3 months (Meher crop only) in 4 regions ( $=4$ environments $x 4$ varieties $=16$ treatments)

- Winter crop 5 varieties ( $=5$ treatments)

Experimental design:

- $\quad$ NUMBER OF TREATMENTS: 49

o 28 treatments (variety $x$ environment)

o $\quad 16$ treatment (variety $x$ storage)

o 5 treatments (Solagrow varieties)

- $\quad$ Take 6 samples from 5 different growers for each treatment (maximally 195 samples to be taken)

Assessments per sample (approximately $5-15 \mathrm{~kg}$ per sample should suffice):

- Weigh $100 \mathrm{~kg}$ (or smaller sample)

- Grading between 45 and $90 \mathrm{~mm}$ (rest $=$ local market)

- Sorting defects, blemishes, misshapen

- Shape length : width ratio $(<1.2=$ crisps, $>1.5$ chips/fries $)$

- Dry matter percentage (oven dried or under water weight)

- Peel percentage peel loss

- Sugars fructose/glucose, fry colour (USDA chart)

- Cutting chips or crisps loss in slivers

- Blanching/Frying post frying weight

- Oil post frying oil content

- Flour grind tuber and oven dry

Reporting

Currently (January 2016) funds are being identified to carry out such study. 


\subsection{Support to the Veris Investment FDOV project}

From April 20-25, 2015 a trip took place to Addis Ababa to hold meetings with representatives of a

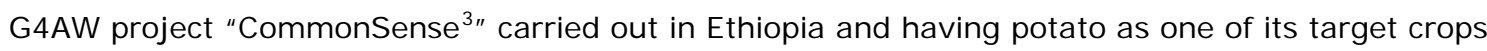
and with Veris Investment ${ }^{4}$.

Present were:

- Veris Investment: Joris de Boer,

- $\quad$ Alterra (Project leader CommonSense with partners Airbus and Apposit; 200,000 growers must be reached in 3 years, viable business and remote sensing must be part): Allard de Wit,

- $\quad$ Airbus (Partner in CommonSense): Sjaak Koot,

- Apposit (Partner in CommonSense, information technology in Agriculture): Adam Abate,

- ABSF: Gertjan Becx,

- $\quad$ Cascape (a Netherlands funded vegetables and fruit project on best practices and scaling up): Mulugeta Diro, and

- $\quad$ Topsector Project PPP India-Ethiopia: Anton Haverkort

\section{Narrative}

Veris Investment Company wanting to establish Senselet, a potato added value company (fresh and crisps). Veris aims at the food value chain in Sub Saharan Africa, improve food security through commercially viable businesses, is based in Netherlands and looks for new businesses. Dual mission: profit making and securing food (doing well by doing good). Tickets $€ 1-10$ million. Availability, Affordability, Stability of value chain. Food, so not coffee, tobacco. Gained a multimillion 7 year lasting FDOV subsidy to establish potato processing (fresh, packed, branded, year round consistent delivery) and crisps line. Later also frozen or chilled fries. Wageningen UR and Solagrow are partners. Project: establish problems, goals and procedures. Envisioned volumes (finished): fresh $1500 \mathrm{t}$ in $20177500 \mathrm{t}$ in 2022. Crisps $60 \mathrm{t}$ in 2017, $400 \mathrm{t}$ in 2022. 2500 growers involved in 2022. Note in 2022 (it is a 7 year project) 7500 t (table) $+400 \times 5$ (recovery) $=7.500+2000=$ says 10,000 of raw material. Ex field this may represent ( $30 \%$ unsuitable) 15,000 tons per annum. Produced by 2,500 growers, so each grower needs to produce 6 tons per annum of which 4 tons delivered. If yield is 24 tons/ha he/she needs $1 / 4$ of a hectare per year. If he has $1 / 2$ hectare farm size with two crops per year $1 / 4$ of his area is dedicated to potato contracted by the factory. The production starts in 2017, potatoes therefore need to be planted in September 2016, its seed for seed needs to be planted now. Solagrow has varieties from the Netherlands for irrigated Courage, Sagitta, Mondial, Ceasar, Red Scarlet, Hermes, Derby. The company also has local varieties (Bupu at Cascape), Balete, Gudene, Jalene suitable for both rainy and dry season (year round). Major diseases are late blight, brown rot and viruses.

Some observations:

- Shops and markets show a wide variation in quality of fresh table potato ranging widely in variety (but all local), age (from freshly harvested to obviously many months old),

- Shops have limited amounts of potato chips (if at all, e.g. none in Ziway found) which shows potential for market but also need for marketing and outlet channels. Shown on market is imported I talian (2.5 times price of local), rather good looking whole chip light coloured to dark crumbs (almost). There is ample quality and price consciousness.

- French fries are a most common component in all restaurants prepared in almost McDonald fashion (near slaughterhouse), intermediate (Kaldi's) or crude (small pieces, varying colours) at e.g. Beergarden Hotel. So there is quality consciousness.

- Solagrow seed potato operations include mini-tuber production of Ethiopian varieties (Gudene, Jalene) for local market and production of seed potatoes of HZPC varieties.

\footnotetext{
${ }^{3}$ www.wageningenur.nl/en/project/Geodata-for-Agriculture-and-Water-CommonSense.htm

${ }^{4}$ www.verisinvestments.com/
} 
Conclusions from meetings and observations from this and previous visits to Ethiopia:

- $\quad$ There are ample markets for fresh potatoes (graded, sorted, washed, packed, branded), chips (crisps) and fries (chilled or frozen),

- Rice, quality, availability, marketing and distribution are to be solved,

- $\quad$ Some NAFTC partners are being approached by Veris Investment for delivery of equipment. 


\section{Moving the Punjab seed potato industry to an environmental robust and internationally competitive level}

Anton Haverkort, Annette Pronk, Bas Janssens \& Sicko de Vries, Wageningen University \& Research, Wageningen, The Netherlands

\subsection{Executive statement}

Punjab is the major supplier of seed potatoes to the rest of India. 1.5 million tons of seed tubers are produced of which ninety percent goes to other Indian states. Domestic need will more than double in the next 30 years while in India a wider range of varieties is needed to accommodate the wide range of growing conditions in the country and where the suitable winter time slot may be reduced by increasing temperatures following climate change. The Country experiences seasonal surplus and shortage depending on a higher than expected crop due to good weather and poor crop due to environment pressure and disease. India has the potential to export Seed Potatoes as well as Ware Potatoes but does not have varieties easily acceptable to the export market which is largely demanding Yellow Flesh European varieties. The other challenge is difficulties in Seed Certification which have encouraged seed growers to either go for truthfully labelled seed as allowed under the law or sell seed potatoes as ware potatoes even though both the buyer and seller know that it is going to be used as seed. A pragmatic and efficient seed certification system would encourage growers to embrace the scheme and help to improve seed quality as well as give assurance to the buyers and facilitate exports. There is also a need to introduce suitable European varieties for multiplication in India to sell as seed to neighbouring countries and export as ware potatoes to neighbouring international markets. The export of seed will augment income of farmers whereas; the export of ware potatoes will not only increase income but also provide price stability in years of surplus production.

\subsection{Reading guide}

This Chapter describes activities carried out to support the Punjab seed potato industry to move to the next level. The activities were to draft a policy note on the actions needed to move the Punjab seed potato industry forwards (par. 9.3 and 9.4) through workshops and meetings with different stakeholders of the Punjabi seed production value chain and a follow up on the drafted policy note: a meeting with Dr. T. Mohapatra, Director Department of Agricultural Research \& Education and Indian Council of Agricultural Research (par. 9.5), to discuss selected findings of the policy note.

\subsection{Introduction}

Globally after wheat and rice, potato is the third food crop and rapidly gaining importance in (sub) tropical regions where the crop now is grown to a wider extent than in temperate climates. Its success follows the wide high yielding ability in a short period of time, its land and water use efficiency, its 
added value in processing and its complementary dietary value. With some countries and regions depending excessively on one single foodstuff such as West Bengal on rice, potato my serve as a desirable variation of the diet. Table 9.1 shows the carbohydrate, energy and protein content of the major staples to be comparable.

Table 9.1.

Components of potato and three other major staple food

\begin{tabular}{|c|c|c|c|c|}
\hline Component (per 100 g dry weight) & Maize & White rice & Wheat & Potato \\
\hline Energy (kJ) & 1696 & 1696 & 1574 & 1533 \\
\hline Fibre (g) & 8.1 & 1.48 & 14 & 10.5 \\
\hline Calcium (mg) & 7.8 & 31.9 & 33.4 & 57.1 \\
\hline Potassium (mg) & 319 & 131 & 417 & 2004 \\
\hline Vitamin C (mg) & 0 & 0 & 0 & 93.8 \\
\hline Vitamin B6 (mg) & 0.69 & 0.18 & 0.35 & 1.43 \\
\hline
\end{tabular}

Source: $h$ ttp://ndb.nal.usda.gov/ndb/search/list

Potato however is much richer in calcium, iron and vitamin B6 and exceptionally rich in potassium and vitamin C. Compared to rice, potato also contains substantial amounts of fibre and calcium. So enhancing potato consumption is an option to supplement needed components to the diet.

The surface of Punjab is just over 50 million hectares, $1.5 \%$ of the total area of India of which $84 \%$ is cropped virtually all under irrigation of which $71 \%$ from tube wells. Multiple crops are sown or planted per year resulting in a cropping intensity of $206 \%$. The total area under potato production in India 1.99 million hectares with an average yield of $22.8 \mathrm{t} /$ ha resulting in a total production is 45.4 million tons. This represents $28 \%$ of the world production with India being the second largest producer of potato after China. Table 9.2 as examples shows the area, yield, annual production and per capita production of Bangladesh, China and the Netherlands along those of India. India has higher yields than the neighbouring countries Bangladesh and China but less per capita consumption so doubling the production will easily be consumed.

Total area under potato in Punjab is 89,000 ha of which 60,000 seed crops, 25,000 ha ware and 4000 ha destined for processing. With an average yield of $25 \mathrm{t} / \mathrm{ha}$ a total Punjab production amounts to 2.2 million t/year of which 1.5 million tons of seed of which around $90 \%$ is exported as seed to other states such as West Bengal, Uttar Pradesh and Gujarat.

\section{Table 9.2}

Potato data from Bangladesh, India, China and The Netherlands

\begin{tabular}{llllll} 
& Area & Yield & Production & Population & Availability \\
Country & $(\mathrm{X} 1000 \mathrm{ha})$ & $\mathrm{t} / \mathrm{ha})$ & $(\mathrm{Mt} / \mathrm{y})$ & 163 & 52.3 \\
Bangladesh & 451 & 18.9 & 8.52 & 1,300 & 35 \\
\hline India & 1,990 & 22.8 & 45.0 & 1,400 & 68 \\
\hline China & 5,770 & 15.4 & 89.4 & 17 & 415 \\
\hline Netherlands & 156 & 45.2 & 7.05 & capita) & \\
\hline
\end{tabular}

Source: http://faostat.fao.org/site/567/

India has over 50 varieties available, all except a few bred by CPRI over the last 50 years. The crisping variety Lady Rosetta and chipping variety Innovator - both from the Netherlands - are examples of non-Indian varieties used by the processing industry. The number of varieties is limited for the number of environments in which the crop is grown in India. When more varieties become available they will yield genotypes that:

- $\quad$ Are more climate and environment robust

- can fulfil the requirements of a rapid growing processing industry

- have export potential as neighbouring countries now import from Europe (e.g. yellow flesh) 
- $\quad$ help develop newer varieties.

The two million hectares of potatoes in India require about three million tons of seed potato tubers. Some $98 \%$ of all potatoes are grown with less than 10 varieties. Seed sources are CPRI that distributes 2,800 t of Breeder seed annually subsequently resulting in Commercial Seed produced by the government sector and 0.2 million tons by the private sector. Assuming a seed replacement rate of $25 \%$, current seed production is 1.6 million tons per annum, about $50 \%$ of the seed need. The rest is farm saved. With the current 3\% annual growth in area the need in 2050 will have more than doubled.

The Punjab Agricultural University estimates a considerable yield increase and improved use of resources when certified seed rather than farm saved is used, well outweighing the costs of certification.

The objective of this policy brief is to explore the advantages of having better seed of a wider range of varieties in India. To this end within the framework of an ongoing Public Private Partnership (PPP) project on potato by the Netherlands Agriculture and Technology Centre (NAFTC) and Wageningen University and Research (WUR) in the Netherlands a high level one day workshop was organized on J une 8, 2016 at the JW Marriott hotel in Chandigarh with a 45 persons audience. The programme of this workshop and speakers is shown in the Annex I.

All speakers have contributed to this Brief and some volunteered to reviewed its text. After the presentations the audience was divided into three groups addressing the question what needs to be done to:

- Make the Punjab seed potato industry important in the region and beyond?

- Make the seed potato certification system contribute more to farmers' income?

- Broaden the (inter)national varietal base to meet current and future industry needs?

Each of these three issues was addressed by exploring the issue, giving recommendations and indicating necessary actions.

As a follow up on the policy brief a meeting with the Ministry of Agriculture was organized to bring the findings to its attention with accompanying background information.

\subsection{Addressing three issues}

\section{I ssue 1: What needs to be done to make the potato seed industry important in the region and beyond?}

Punjab region is capable of competitively producing best quality seed potatoes due to its having right mix of land, water, environment and entrepreneurship. There is sufficient demand domestically and for exports to neighbouring countries for good quality seed, and it is a profitable business area in the long run but there are three major challenges:

- Acceptance of Indian seed (country brand) as it does not have a good presence yet

- Countries that may want to import seed from India need different varieties than currently available in India

- Registration and notification is an issue: procedures are lengthy and lack of breeders' rights protection make foreign breeders reluctant to introduce varieties to India

Recommendations and Action Points

- $\quad$ Form a Potato Association consisting of all Stakeholders, with clearly defined objectives. The key objectives discussed are promotion and marketing of Indian brand in exports markets, be a prominent platform to discuss and find solutions to the issues faced by Potato industry, and act to influence and help develop right government policies. This is seen as a non-Government organisation which will be funded by the stakeholders and the terms of reference will be decided by a key group set up by the stakeholders. 
- Reduction of disease pressure by reducing the source of inoculum by pushing for legal solution, a legislation by Punjab Government, by demarcation of seed potato growing areas, with restriction on table/processing potato cultivation in that area. As a first step Industry leaders to mutually agree on small area (may be a Tehsil) and work together to provide parent seed and market access to prove that farmers will gain by this step and promote voluntary participation and then once success is achieved in this small pocket, then showcase this to the Government \& it's agencies and push for legislation on demarcation of areas and other important practices to ensure production of best quality seeds.

- To form a small working group with all stakeholders to prepare a presentation on business plan (e.g. cost-benefit analysis, competence analysis) and convince the long term commercial advantages linked with promotion of voluntary certification and quality seed production hub in Punjab. Same group discusses with CPRI the gaps in pipeline material availability for the targeted potato production, and agree on data on current situation and gaps, and push for Minitubers from all production sources to be considered as nuclear seed stage.

- As Certification is important and it would be useful to have an Independent Private Body accredited by the Government and its institutions for certification for domestic sales.

- Certification for exports: To have a body made responsible with adequate resources, to certify the seeds as per requirements of importing country, both for notified and non-notified varieties. Government to have bilateral agreements with importing countries (like is the case with the Netherlands).

\section{I ssue 2: What needs to be done to make the seed potato certification system contribute more to farmers' income?}

Currently less than $1 \%$ of seed potatoes in India is certified/truthfully labelled. The current informal system is amenable to improvement and hampers export of seed potatoes as importing countries observe strict norms for seed potatoes health and infection with viruses, fungi, bacteria and pests. The major challenges are:

- $\quad$ Establishing the benefits of an effective seed certification system

- The creation of an accredited certification body

- Certification of non-notified varieties

Recommendations and Action Points

- There is a need to promote seed purchase from certified/accredited agency and to investigate the gap between demand and supply and to calculate the costs and benefit of the system at grower's level.

- A seed certification consortium needs to be established consisting of representatives of growers, the processing industries.

- The law regarding all aspects of seed such as mandates, accreditation, pricing, needs to be amended with all stake holders. Mini-tubers should be accepted as nuclear seed, this needs adaptation in legislation.

- To have an autonomous certification body approved by the stakeholders among them the state and central governments possibly supervised by a governmental institution.

- Certification agency norm should be updated with current technical new insights and techniques and current environmental conditions (new vectors and diseases) and benchmarked against those of seed exporting countries.

- Make similar conditions like "RUCIP" (Rules and Practices of the Inter-European Trade in Potatoes) for complaints.

I ssue 3: What needs to be done to broaden the (inter) national varietal base to meet current and future industry needs?

CPRI has bred varieties suitable for the Indian Sub-Continent and there is a need to further supply climate robust genotypes; also there are some crops especially in the area of processing $\&$ exports where there are gaps. There are also international varieties which could add value to India's objective of increasing potato production to meet the growing need of its population. 
- Foreign suppliers of varieties are reluctant to supply material yet there is much out there that may be of use as variety or parental material for the diversity of (changing) environments, pests and diseases. Mass screening of such material would require legal binding transfer agreements to overcome restraint of foreign suppliers.

- The procedures of registration (DUS) and Notification are lengthy therefore they should be condensed and overlapping each other rather than waiting to start notification procedures before DUS testing is finished.

- Registration and Notification need to be carried out by an independent body

- Yield as one of the notification requirements should be viewed pragmatically as this may not always be relevant, e.g. for a processing variety suitability is more important than yield

- Current regulation stipulates that imported exotic varieties can be used for research purpose only. For registration purposes this clause needs to be modified.

Varieties existing for many years in the farming community can be registered when accompanied by a specific and appropriate "package of practices". To help the process CPRI should assist growers to establish such 'package'.

\subsection{Follow up on the policy brief Punjab Seed Potato}

A meeting with the Ministry of Agriculture was organised in Delhi to bring the findings of the Policy Brief Punjab Seed Potato to its attention, to provide background information and to exchange views on how findings could be accommodated. The meeting was attended by:

Dr. T. Mohapatra, Director Department of Agricultural Research \& Education and Indian Council of Agricultural Research (ICAR), on behalf of the Minister of Agriculture,

Dr. S.K. Chakrabarti, Director Central Potato Research Institute (CPRI)

Dr. T. Janakiram, Assistant Director General Indian Council of Agricultural Research (ICAR)

Mr. W. (Wouter) Verhey, Agricultural Counsellor India \& Sri Lanka, Embassy of the Kingdom of Netherlands

Prekash Ramsingh, Interim Director NAFTC India

Pooja Chaudhry, Senior Policy Advisor for Agriculture, Nature \& Food Quality India \& Sri Lanka, Embassy of the Kingdom of Netherlands

Dr. A.A. (Annette) Pronk, Potato Specialist, Agronomist, WUR

S.R.M. (Bas) Janssens, Economist, WUR

S. (Sicko) de Vries, Agronomist, WUR

A short introduction of the meetings was done by Mr. Verhey. He highlighted findings presented in the Policy Brief Punjab Seed Potato (par. 9.3). The Policy Brief needed some additional explanation which was kindly provided by CPRI and ICAR representatives. Two main topics for the meeting were introduced by the Dutch Agricultural Counsellor:

issue 1: What needs to be done to broaden the (inter)national varietal base to meet current and future industry needs?

issue 2: What needs to be done to make the seed potato certification system contribute more to farmers' income?

\section{Background}

The potato value chain in India has basically three main domains: the potato market (fresh, processing), the potato production and seed potato production. Seed potato production is characterized to be a potentially very profitable business. The State of Punjab is by geographical characteristics, eminently well suited to produce seed potatoes and is the major seed producing State 
of India. Where India's need for seed potatoes is estimated at 4 million tons ( 40 lakhs; $\approx 2$ million ha

(Table 9.2 ) $* 2$ tons seed/ha), less than $20 \%$ is certified/truthfully labelled (Table 9.3 ).

\section{Table 9.3}

The estimated availability of seed potatoes by different producers

\begin{tabular}{ll} 
Producer & Amount \\
Certified seed, Government sector & 0.6 million tons \\
\hline Certified seed, private sector & 0.2 million tons \\
\hline Non-certified seed, private sector & 1.5 million tons \\
\hline Total available & 2.3 million tons \\
\hline
\end{tabular}

The economic opportunity for Punjab's seed production is the production of an additional 1.7 million tons of certified seed, which roughly represents an economic value of 34,680 million IND or 1200 million US\$5 $(1.7$ million tons $* 300$ US\$).

When a trustworthy seed certification system is in place, export of seed potatoes to neighbouring countries becomes an additional economic opportunity for Punjab's seed producers to increase farmers income. The total import of India's five neighbouring countries represents an economic value of $\approx 809$ million INR or $\approx 12$ million US\$ ( $\approx 24000$ tons $* 500$ US\$/ton). The State of Punjab has the potential to become an important seed hub for the region.

However, the Policy Brief indicated several issues that need to be addressed in order to redeem this value.

Table 9.4

Overview of estimated import needs for seed potatoes of India's neighbouring countries

\begin{tabular}{lllll} 
Particulars & Pakistan & Bangladesh & Sri Lanka Thailand Myanmar \\
Area harvested (FAO STAT 2013, ha) & 172,000 & 443,934 & 5,140 & 7,010 \\
\hline Seed planted (FAO STAT 2013, tons) & 172,000 & 443,934 & 9,300 & 7,164 \\
\hline Seed Rate (tons/ha) & 1.00 & 1.00 & 1.81 & 1.000 \\
\hline Total import 2014-15 (tons) & 13,189 & 4,446 & 1,650 & 0.64 \\
\hline
\end{tabular}

\section{I ssue 1: What needs to be done to broaden the (inter) national varietal base to meet current and future industry needs?}

The varietal base is currently identified as too small to meet the market demand. India has approximately 50 varieties available which accommodate different uses. In the discussion on varietal base, the possibility was explored to breed new varieties in consultation with end uses, stakeholders, who indicated to be in need of customized varieties. An additional focus might be the specific demands from neighbouring countries. CPRI expressed interest to jointly look into market demands to be included in the breeding process.

The possibility to speed up the availability of customized varieties by import of existing foreign varieties was discussed. The process of releasing new varieties to the market is experienced as a long and complicated process of which no transparent pathways and/or procedures with time tables appear to be available. It was assured that the procedure is transparent and available. In short, the fastest track for release of imported varieties is approximate 5 years and has two parts: first, 2 years for quarantine testing and second, 2 to 3 years for identity testing (DUS = distinctiveness, uniformity and stability). After passing the quarantine and DUS testing, the variety is registered which allows the variety to be propagated and sold. The CPRI supervises the procedure where the independent University carries out the testing.

Concerns are that DUS testing is dominated by yield performance which may not be the main focus when market demand is for specific quality characteristics such as dry matter content or sugar

\footnotetext{
${ }^{5}$ Exchange rate: 1 US $\$=68$ INR
} 
content. It was expressed by CPRI that the focus in DUS testing has been extended to include quality characteristics which are then considered to be equally important related to the expected potato use.

\section{I ssue 2: What needs to be done to make the seed potato certification system contribute} more to farmers' income?

The Seed Certification system in India is confined to notified varieties under Section- 5 of the Indian Seed Act, 1966. This Seed Act of 1966 provided the required impetus for the establishment of official Seed Certification Agencies by the States. Seed certification therefore is a State responsibility. This situation is not to be changed, not for non-notified varieties or to establish a National Certification Body.

There are clear guidelines for certification so if there are any issues raised, the State's Seed Certification Agencies should be consulted and addressed locally. Seed Certification is mandated to these established Seed Certification Agencies at the State's level and not an activity of the National Government. 


\section{Communication}

Ben Meijer, Wageningen University \& Research, Wageningen, The Netherlands

\subsection{Missions, symposia, contacts}

1. Meeting with Mooy, 21 January 2015. Van den Brink \& Meijer. Discussion of 2014 project results and plans for storage trials 2015.

2. Meeting with HZPC, 23 January J oure. Haverkort and Meijer. Discussion of project results and plans for 2015.

3. Meeting with Omnivent, 27 January Zeewolde. Van den Brink \& Meijer. Discussion of 2014 project results and plans for storage trials 2015.

4. Mission to Punjab. 26 - 31 January 2015. Haverkort, Wustman and Meijer. Meetings with PAU, POSCON, HZPC - Mahindra, Round table meetings in Chandigarh, Meeting with Mr. Bhatti and dr. Ghang. Meeting with Marijn Leijten and Ravindra in Delhi.

5. Visit to Gujarat, 31 January - 2 February 2015. Wustman and Meijer. Meeting with Mr. Abinash Gupa (Mc Cain), mr. Rhohit Bhandari \& dr. Rakesh Singh (Omnivent).

6. Meeting with Kiremko, 11 - February 2015, Montfoort. Janssens and Meijer. Discussion of 2014 project results and plans for 2015.

7. NAFTC project meeting, 16 February 2015 Zoetermeer. Leijten, Vernooij, Haverkort, Kempenaar, Meijer.

8. NAFTC Dutch Potato Board meeting, 18 February 2015 Zoetermeer. Kempenaar, Haverkort, Meijer and members of Dutch Potato Centre. Presentation of 2014 project results and work plans for 2015.

9. Visit to Gujarat, 24 February - 5 March 2015. Van den Brink. Storing potato samples in traditional stores and upgraded and new stores built by Omnivent and Mooy. Meetings with their representatives and Mc Cain.

10. NAFTC project meeting, 3 March 2015 Zeewolde. Groenewoud, Vernooij, Kempenaar, Meijer.

11. WUR project meeting 10 April Wageningen. Kempenaar, Haverkort, Meijer, Wustman, Pronk, Michielsen, Janssens, Schoutsen.

12. Project mission to Gujarat, 25 - 31 July 2015. Visit to McCain in Mehsana, McCain-store in Himmatnagar, meeting with Hyfun Food and Simplot.

13. Mission to Punjab and Gujarat, 10 - 17 September 2015. Janssens, Pronk \& Ter Beke. Meetings with NBSO, McCain, Hyfun Food and Simplot; visit Asian Fair, Gujarat. Meetings Poscon, Punjab, Mr. Bhatti. Presentations at Agri Asia Fair and Poscon meetings.

14. NAFTC mission to Punjab and Gujarat; Dutch Potato Week, 3 - 9 October 2015. Wustman, Michielsen and Meijer (WUR), Groenewoud, Kok, Ramsingh, Praneet, Ashish, Mooy, Adrigem, Somu (NAFTC). Presentations and discussions at seminars and workshops in Gujarat and Punjab.

15. NAFTC meeting with Marijn Leijten and Prekash Ramsingh. 18 J une 2015. Haverkort, Kempenaar, Meijer.

16. NAFTC Dutch Potato Board meeting on $24 \mathrm{~J}$ une at Emmeloord (Verbruggen). Meijer, members of Dutch Potato Centre.

17. Project mission to Gujarat, 25 - 31 July 2015 L. van den Brink. Meeting with McCain in Mehsana, visit to McCain-store in Himmatnagar. Meetings with Hyfun Food and Simplot

18. NAFTC Dutch Potato Centre meeting on 4 September 2015 at Zeewolde. Meijer, Groenewoud, Ramsingh, Vernooij.

19. Project Mission to Gujarat, 8 - 13 December 2015. L. van den Brink \& f. ter Beke. Visits to McCain in Mehsana, McCain-store in Himmatnagar and Omnivent store in Himmatnagar. Meeting with Simplot.

20. Project Mission to Punjab, 14 - 17 December 2015. F. ter Beke. Field visits and discussions with POSCON. 
21. Mission to Punjab for research on haulm killing. 26 December 2015 - 6 January 2016. Jean-Marie Michielsen.

22. Project PPP meeting. 5 January 2016, Zeewolde.

23. Project mission to Punjab: Experiments on skin curing. Meeting with (local) representatives of Bayer, Syngenta and Teejet at Poscon meeting about the use of chemicals and application techniques. 21-28 January 2016, Jean-Marie Michielsen

24. Project mission to Punjab: Experiments on skin curing \& visit at HZPC-Mahindra demo field. 713 March 2016, Jean-Marie Michielsen

25. Project mission to Gujarat and Punjab: NAFTC Final workshop on project results. 10-17 December 2016. A.A. Pronk, S.R.M. Janssens, S. de Vries, Praneet Pathak.

26. Project trip to Delhi. Meeting with Dr. T. Mohapatra, Director Department of Agricultural Research \& Education and Indian Council of Agricultural Research (ICAR), 13 December 2016. A.A. Pronk, S.R.M. Janssens, S. de Vries, W. Verheij, Prakesh Ramsing, Poone Chaudhry.

\subsection{Presentations}

1. Michielsen, J.G.P., 2015. Mechanisation Potato India. Workshop Dutch Potato Week, NAFTC, Gujarat 5-6 October 2015.

2. Michielsen, J.G.P., 2015. Mechanisation Potato India. Workshop Dutch Potato Week, NAFTC, Punjab 8-9 October 2015.

3. Meijer, B.J.M., 2015. Wageningen-UR in a nutshell. Workshop Dutch Potato Week, NAFTC, Gujarat 5-6 October 2015.

4. Meijer, B.J.M., 2015. Potato Production Chain India. Plenary presentation Dutch Potato Week, NAFTC, Gujarat 5-6 October 2015.

5. Meijer, B.J.M., 2015. Potato Production Chain India. Plenary presentation Dutch Potato Week, NAFTC, Punjab 8-9 October 2015.

6. Meijer, B.J.M., 2015. Wageningen-UR in a nutshell. Workshop Dutch Potato Week, NAFTC, 8-9 October 2015, Punjab, India.

7. Pronk, A.A. \& S.R.M. Janssens, 2015. Gujarat Seed Potato Valley: Boundary conditions, requirements and finances. Presentation at seminar seed valley during the Agri Asia Fair, 10 September 2015.

8. Pronk, A.A. \& S.R.M. Janssens, 2015. Punjab Seed Potato: Opportunities for a bag less potato value chain. Presentation for POSCON board and general meeting of POSCON, 17 September 2015.

9. Pronk, A.A. \& S.R.M. Janssens, 2015. Punjab Seed Potato: Opportunities for a bag less potato value chain. Presentation for general members meeting of POSCON, 17 September 2015.

10. Ter Beke, F.B.M., 2015. Root development and making potato ridges. POSCON Workshop during Potato mission 14 - 17 December 2015.

11. Wustman, R., 2015. Seed potato concepts India. Workshop Dutch Potato Week, NAFTC, Gujarat 5- 6 October 2015.

12. Wustman, R., 2015. Need for storage. Workshop Dutch Potato Week, NAFTC, Gujarat 5-6 October 2015.

13. Wustman, R., 2015. Seed potato concepts India. Workshop Dutch Potato Week, NAFTC, Punjab 8- 9 October 2015.

14. Wustman, R., 2015. Need for storage. Workshop Dutch Potato Week, NAFTC, Punjab 8-9 October 2015.

15. Haverkort, A.J., 2016. Industry Benchmark and some best practices by NAK - seed inspection, seed certification and legislation for propagation. One day workshop on variety registration and seed certification, $8^{\text {th }}$ J une 2016 , Chandigarh, Punjab, India.

16. Janssens, S.R.M., 2016. Cost/benefit analysis potato cropping: Comparison of 3 systems: traditional-upgrade-advanced. Final Meeting PPP, 14 ${ }^{\text {th }}$ December 2016, Gandhinagar, Gujarat, India. 
17. Janssens, S.R.M., 2016. Cost/benefit analysis potato cropping: Comparison of 3 systems: traditional-upgrade-advanced. One day workshop on "Strengthening Indian Potato Value Chain: minimising losses to increase farm income", 16 ${ }^{\text {th }}$ December 2016, Chandigarh, Punjab, India.

18. Pronk, A.A., \& R.S. Somashekhar, 2016. Variety Registration and Seed Certification: steps to be taken. One day workshop on "Strengthening Indian Potato Value Chain: minimising losses to increase farm income", 14 $4^{\text {th }}$ December 2016, Gandhinagar, Gujarat, India.

19. Pronk, A.A., \& R.S. Somashekhar, 2016. Variety Registration and Seed Certification: steps to be taken. One day workshop on "Strengthening Indian Potato Value Chain: minimising losses to increase farm income", $16^{\text {th }}$ December 2016, Chandigarh, Punjab, India.

20. Vries, de S., 2016. Potato storage - quality \& storage losses. One day workshop on "Strengthening Indian Potato Value Chain: minimising losses to increase farm income", $14^{\text {th }}$ December 2016, Gandhinagar, Gujarat, India.

21. Vries, de S., 2016. Potato storage - quality \& storage losses. One day workshop on "Strengthening Indian Potato Value Chain: minimising losses to increase farm income", $16^{\text {th }}$ December 2016, Chandigarh, Punjab, India.

\subsection{Publications}

1. De Snoo, A., 2015. India wil Nederlandse aardappelkennis. Nieuwe oogst, 7 maart 2015, pag. 4.

2. Haverkort, A.J., 2015. Impressions of IlanBio's micro-tubers, production, use and R\&D aimed at exploitation. Mission report, WUR, this report.

3. Janssens, S.R.M., M. Schoutsen, 2015. Market study into the developments of 1) the Quick Service Restaurant business and 2) the potato snack (chips) business in India, Annual report topsector potato India and Ethiopia 2014.

4. Janssens, S.R.M., A.A. Pronk \&J.M. Michielsen, 2015. Possible benefits of mechanization in potato production and handling, Annual report topsector potato India and Ethiopia 2014.

5. Van den Brink, L., 2015. Report on storage experiments in McCain/Mooij stores 2013 and 2014, this report.

6. Pronk, A.A. \& Michielsen, J.G.P., 2015. Improved skin curing to facilitate mechanical harvest of seed potatoes in Punjab, India. Field trial proposal. WUR, 8 pp.

7. Pronk A.A., R. Wustman, A.J. Haverkort, L. van den Brink, S.R.M. Janssens \& M. Schoutsen, 2015. Annual report topsector potato India and Ethiopia 2014. Applied Plant Research \& Plant Research International, part of Wageningen UR, Business Unit Agrosystems Research/Arable Farming, Multifunctional Agriculture and Field Production of Vegetables, Wageningen. 


\section{References}

Anonymous, 2015a. CPRI vision 2050, Central Potato Research Institute \& Indian Council of Agricultural Research, New Delhi, India, $33 \mathrm{pp}$.

Anonymous, 2014. A long way from the supermarket: Modern food retailing has struggled to win customers from India's old-fashioned merchants. www.economist.com/news/business/21625799-modern-foodretailing-has-struggled-win-customers-indias-old-fashioned-merchants-long. [accessed 2016 Feb 28].

Anonymous, 2013. Not always with us. The world has an astonishing chance to take a billion people out of extreme poverty by 2030. www.economist.com/news/briefing/21578643-world-has-astonishing-chancetake-billion-people-out-extreme-poverty-2030-not. [accessed 2016 J an 10].

Anonymous, 2015b. Packaged Food in India. www.euromonitor.com/packaged-food-in-india/report. [accessed 2016 Feb 20].

Bethke P.C. \& J.S. Busse, 2010. Vine-Kill treatment and harvest date have persistent effects on tuber physiology. American Journal of Potato Research 87, 299-309.

Bouman A., J. Bouma \& A. Mulder, 1983. Effects of time and method of leaf destruction on the skin pealing sensitivity and on the severity of Rhizoctinia solani on seed potatoes [in Dutch: Effecten van tijdstip en wijze van loofvernietiging op de ontvellingsgevoeligheid en op de bezetting van pootaardappelen met Rhizoctonia solani $=$ The effect of moment and method of haulm distroying on the tendences of skinning and the infection of seed potatoes with Rhizoctonia solani]. IMAG, Wageningen.

Dobbs R., S. Smit, J. Remes, J. Manyika, C. Roxburgh \& A. Restrepo, 2011. Urban world: Mapping the economic power of cities, McKinsey Global Institute, $49 \mathrm{pp}$.

Government of India, 2015. Growth of Electricity Sector in India From 1947-2015. www.indiaenvironmentportal.org.in/files/file/growth_2015.pdf. [accessed 2016 Jan 10].

Halderson J.L. \& R.C. Henning, 1993. Measurements for determining potato tuber maturity. American Potato Journal 70, 131-141.

Kempenaar C. \& P.C. Struik, 2007. The canon of potato science: 33. Haulm killing. Potato Research 50, 341345.

Kumar P. \& N. Dangi, 2013. Rural Marketing in India: Challenges and Opportunities. International J ournal of Management and Social Sciences Research (IJMSSR) 2, 93-100.

Lulai E.C., 2007. Skin-set, wound healing, and related defects. In Potato Biology and Biotechnology: Advances and Perspectives. pp. 471-500. Elsevier.

Lulai E.C. \& P.H. Orr, 1993. Determining the feasibility of measuring genotypic differences in skin-set. American Potato Journal 70, 599-609.

Mittal V., 2013. Challenges faced by Indian frozen food sector today. www.fnbnews.com/TopNews/Challenges-faced-by-Indian-frozen-food-sector-today. [accessed 2016 Mar 1].

Molema G.J., A. Bouman \& L.J. Turkensteen, 1995. Groenrooien en onderdekken als alternatief voor chemische loofdoding in aardappelpootgoed : onderzoek naar de effectiviteit van de loofdoodmethode, de ontwikkeling van lakschurft en het verloop van de ontvellingsgevoeligheid in de tijd = Green-crop lifting as alternative for chemical haulm killing in seed - potatoes. IMAG-DLO, Wageningen.

NHB, 2011. National Horticulture Database 2011.

Nielsen White Paper, 2012. Emerging Consumer Demand: Rise of the Small Town Indian, Confederation of Indian Industry (CII) and Nielsen India, Mumbai, India, $19 \mathrm{pp}$.

O'Leary A.G. \& W.M. I ritani, 1969. Potato bruise detection. American Potato J ournal 46, 352-354.

Pavlista A.D., 2002. Skin set evaluation by skin shear measurements. American J ournal of Potato Research 79, 301-307.

Sharma J., 2014. Frozen Food Category to Grow by 11 Percent. www. indiaretailing.com/2014/08/06/progressive-grocer/frozen-food-category-to-grow-by-11-percent/. [accessed 2016 Jan 8].

Singh K., 2014. Retail Sector in India: Present Scenario, Emerging Opportunities and Challenges. Journal of Business and Management 16, 72-81.

Vanitha S.M., S.N.S. Chaurasia, P.M. Singh \& P.S. Naik, 2013. Vegetable Statistics. Vegetable production in India (2000 -2001 to 2010-2011), Indian Institute of Vegetable Research, Varanasi, 250 pp.

Winter M.A., 2008. Modern retail and traditional kirana stores will coexist. www.foodindustryindia.com/newfood/detailnews.jsp?n=Modern+retail+and+traditional+kirana+stores+w ill+coexist\&id $=532$. [accessed $2016 \mathrm{~J}$ an 10].

Wustman R., A.J. Haverkort, X. Zhang \& G. Rathee, 2011. An overview of the potato sector in India and prospects of Indo \& Dutch cooperation, Applied Plant Research, WUR, Wageningen, 73 pp. 


\section{Annex 1 Trips program and participation 2015}

2015

Visit Anton Haverkort with Poscon members to IlanBio, I srael

Liam Gal-On (liam@ilanbio.com) CEO, Elliot Spitz Director Business Development, two more Ilan Bio technicians Mr Batti and Dr Gang from Jalandhar, India

Tuesday April 28

Departure Amsterdam

Wednesday April 29

Arrival Tel Aviv

Wednesday April 29

Morning Visit Agritech

Afternoon Seminar "Reducing Food Waste" Delivery of pitch on "Recovery"

Thursday April 30

All day trip to Negev with Mr Sujit Bjatti and Dr Gang of POSCON India

and IlanBio personnel (Elliot, Liam, Yaakov Cohen,...) to Ramat Negev Mountain Research Station

Late afternoon: Visit EGO packing station

Evening dinner with Jan Hak Mr Batti and Dr Gang

Friday may 1

Departure from Tel Aviv, Arrival at Amsterdam Airport. 


\section{Annex 2 The BBCH scale for determination of the growth stage}

The $\mathrm{BBCH}$ scale as used to indicate the crop growth stage. This is important as chemicals have different effects in different growth stages.

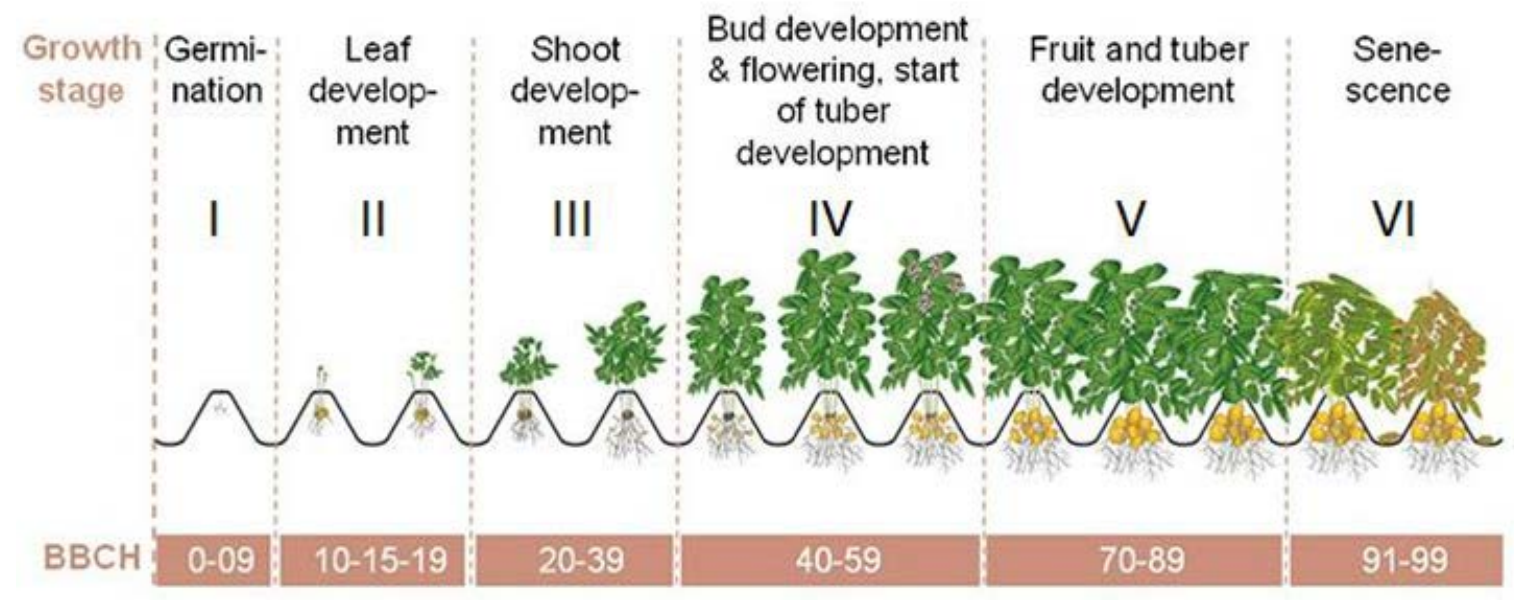




\section{Annex 3 One day workshop on seed potatoes, $8^{\text {th }}$ J une 2016, JW Marriot, Chandigarh, Punjab}

Organized by: $\quad$ Embassy of the Kingdom of The Netherlands, Netherlands Agro Food \& Technology Centre (NAFTC) \& Wageningen University \& Research (WUR).

Chief Guest: $\quad$ Dr. R.C. Agarwal, Registrar General, Protection of Plant Varieties \& Farmers' Right Authority, Government of India

Guest of honour: Dr. S.K. Chakrabarti, Director Central Potato Research Institute (CPRI)

09:30 Opening addresses

- $\quad$ Welcome \& lamp lightning.

- $\quad$ Introducing, welcoming guests \& presenting flowers.

- $\quad$ Opening address by the Chief Guest Dr. R.C. Agarwal, Registrar (Horticulture), Protection of Plant Varieties \& Farmers' Right Authority

- $\quad$ Opening\& welcome address- Mr. Wouter Verhey, Agriculture Counsellor- India, Embassy of the Kingdom of The Netherlands

- $\quad$ Opening $\&$ briefing the workshop (Objective $\&$ Agenda) - Prof. Dr. A.J. Haverkort, WUR

- $\quad$ Opening by Dr. M.S. Dhaliwal, Additional Director Research, PAU: Importance of quality seed in potato cultivation.

10:30 Current practices\& requirement of changing process in variety evaluation and seed production system

Mr. Sukhjit Singh Bhatti, President of POSCON - I mportance \& advantages of registration of foreign varieties of potato in India - Farmer perspective

Mr. Davinder Singh, Mahindra HZPC - Why changes are required in the current processes and how new practices will add value to Indian potato value chain

11:00 High tea

11:15 Prof. Dr. A.J. Haverkort: Industry Benchmark \& some best practices by NAK - Seed inspection, seed certification \& legislation for propagation.

11:30 Dr. S.K. Chakrabarti, Director CPRI - Official procedure of commercial registration of varieties\& the required changes

12:00 Dr. R.C. Agarwal, Registrar General, PVP\&FR: Provisions of Plant Variety Protection (PVP) legislation in India with special reference to potatoes.

12:30 Mr. Shri Jasvir Singh Bains, Director Agriculture, Punjab - Brief of Government schemes \& programs that supports farmer community

14:00 Lunch

15:00 Break out session in three groups: What needs to be done to:

1. Make the Punjab seed potato industry important in the region and beyond?

2. Make the seed potato certification system contribute more to farmers' income?

3. Broaden the (inter)national varietal base to meet current and future industry needs?

15:00 Reporting in plenary setting of the three groups

16:00 Formulation of recommendations, follow up and task-force

16:4 Summary of recommendations: Dr. R.C. Agarwal, Dr. S.K. Chakrabarti, Prof. Dr. A.J . Haverkort

17:10 Vote of thanks - Mr. Wouter Verhey, Agriculture Counsellor India, Embassy of the Kingdom of The Netherlands

17:20 Tea \& discussion 


\section{Annex 4 One day workshop on strengthening Indian potato value chain: minimising losses to increase farm income, $14^{\text {th }}$ December 2016, Fortune Inn Haveli, Gandhinagar, Gujarat}

Organized by: Embassy of the Kingdom of The Netherlands, Netherlands Agro Food \& Technology Centre \& Wageningen University \& Research, The Netherlands.

Chief Guest: $\quad$ Dr. B.R. Shah, Director of Agriculture, Government of Gujarat

Guest of Honour: Dr. R.A. Sherasia, Director of Horticulture, Government of Gujarat

\section{9:30 Opening addresses}

- $\quad$ Welcome \& lamp lightning

- $\quad$ Introducing, welcoming guests \& presenting flowers

- $\quad$ Opening address by the Chief Guest, Dr. B.R. Shah, Director of Agriculture, Government of Gujarat

- $\quad$ Opening address by the Guest of Honour, Dr. R.A. Sherasia, Director of Horticulture, Government of Gujarat

- $\quad$ Opening \& briefing the workshop (Objective \& Agenda)- Sicko de Vries, Wageningen University \& Research

10:30 Dr. Annette Pronk, Wageningen University \& Research: Variety Registration \& Seed Certification- STEPS TO BE TAKEN

\section{1:15 Hi tea}

11:30 Bas J anssens, Wageningen University \& Research: Cost/Benefit analysis- Potato cropping

12:15 Sicko de Vries, Wageningen University \& Research: Potato storage - quality \& storage losses Addressing losses in potato stores during the storage season - a comparison of three systems- traditional, upgraded \& advance storage techniques, taken into consideration the storage trials set-up in India in the previous two years.
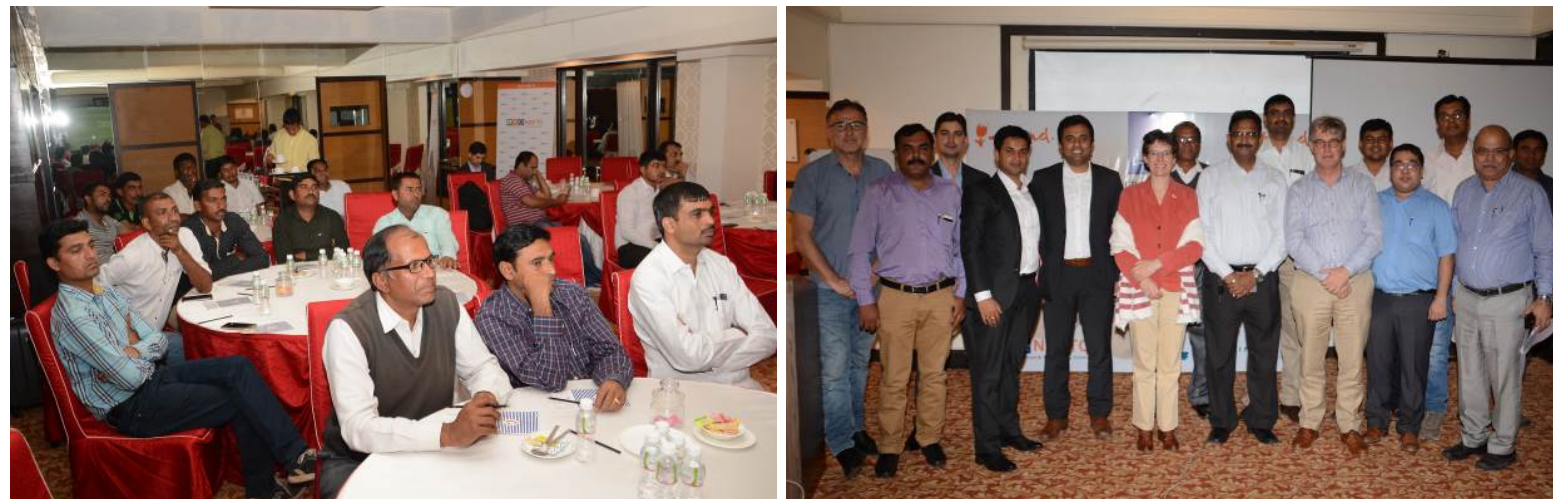

13:00 Lunch 
14:00 Dividing into three groups for breakout session

14:15 Breakout session

Topics of breakout session:

WHAT NEEDS TO BE DONE:

\section{Seed \& varieties:}

The Indian seed potato system, includes: many registered varieties / a well-organized certification system / a financial breeder right system by year 2025 .

\section{Economics:}

The Indian potato value chain will be totally bag-less by year 2035

\section{Storage:}

The Indian potato cold store design and management is completely based upon the "advanced system" by year 2030

Steps of discussion: What kind of actions are needed - what are the recommendations - who will be responsible - in which time frame

15:15 Organizing back in the main workshop hall

15:30 Presentation by groups \& discussion over recommendations

16:15 Question \& answer session

16:45 Closing remarks \& vote of thanks

17:00 Session ends: Tea 


\section{Annex 5 One day workshop on strengthening Indian potato value chain: minimising losses to increase farm income, $16^{\text {th }}$ December 2016, JW Marriott, Chandigarh, Punjab}

Organized by: Embassy of the Kingdom of The Netherlands, Netherlands Agro Food \& Technology Centre (NAFTC) \& Wageningen University \& Research (WUR), The Netherlands.

Chief Guest: Dr. Gurkanwal Singh, Director of Horticulture, Government of Punjab

Guest of honour: Dr. S.K. Chakrabarti, Director-CPRI

09: 30 Opening addresses

- Welcome \& lamp lightning

- $\quad$ Introducing, welcoming guests \& presenting flowers

- $\quad$ Opening address \& introduction by CPRI - Chief Guest, Dr. S.K. Chakrabarti, Director CPRI

- $\quad$ Opening \& briefing the workshop (Objective \& Agenda)- Sicko de Vries, Wageningen University \& Research

10:15 Mr. Davinder Singh, MHZPC: Current issues being faced by Seed Potato growers in Punjab \& possible options as solutions

10:30 Dr. Annette Pronk, Wageningen University \& Research: Variety Registration \& Seed Certification- STEPS TO BE TAKEN

11: $15 \mathrm{Hi}$ tea

11:30 Bas J anssens, Wageningen University \& Research: Cost/Benefit analysis- Potato cropping

12:15 Sicko de Vries Wageningen University \& Research: Potato storage - quality \& storage losses Addressing losses in potato stores during the storage season - a comparison of three systems- traditional, upgraded $\&$ advance storage techniques, taken into consideration the storage trials set-up in India in the previous two years.
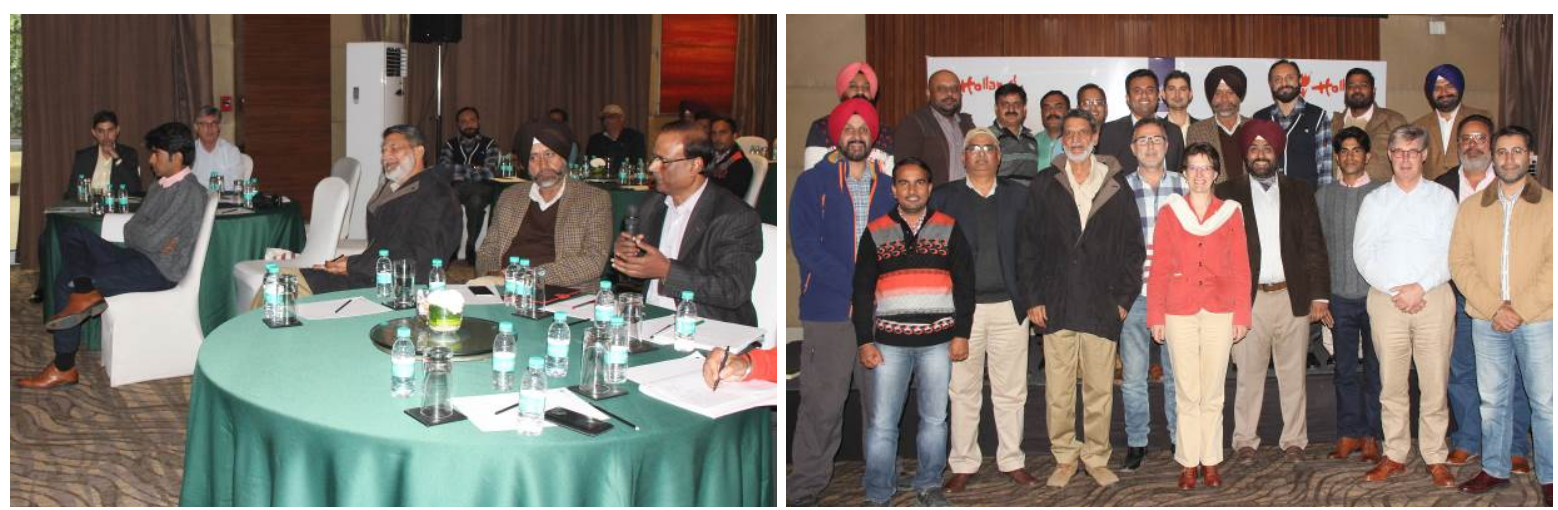

13:00 Lunch 
14:00 Dividing into three groups for breakout session

14:15 Breakout session

Topics of breakout session:

WHAT NEEDS TO BE DONE:

\section{Seed \& varieties:}

The Indian seed potato system, includes: many registered varieties / a well-organized certification system / a financial breeder right system by year 2025 .

\section{Economics:}

The Indian potato value chain will be totally bag-less by year 2035

\section{Storage:}

The Indian potato cold store design and management is completely based upon the "advanced system" by year 2030

Steps of discussion: What kind of actions are needed - what are the recommendations - who will be responsible - in which time frame

15:15 Organizing back in the main workshop hall

15:30 Presentation by groups $\&$ discussion over recommendations

16:15 Question \& answer session

16:45 Closing remarks \& vote of thanks

17:00 Session ends: Tea 

Corresponding address for this report:

\section{P.O. Box 16}

6700 AA Wageningen

The Netherlands

$T+31(0) 317480700$

www. wur.eu/plant-research

Report WPR-687
The mission of Wageningen University and Research is "To explore the potential of nature to improve the quality of life". Under the banner Wageningen University \& Research, Wageningen University and the specialised research institutes of the Wageningen Research Foundation have joined forces in contributing to finding solutions to important questions in the domain of healthy food and living environment. With its roughly 30 branches, 5,000 employees and 10,000 students, Wageningen University \& Research is one of the leading organisations in its domain. The unique Wageningen approach lies in its integrated approach to issues and the collaboration between different disciplines. 